مجلة تربويات الرياضيات - المجلا (9 ( ) العدد (Y) يناير 17 ـ ب م الجزء الثاني

نموذه تدربسي مقتزع قاتم على التعلم السريج لتنمية التفكير الجانبي

والتنظيم الثاتي في الرباضيات لدى تلاميد الصف الثاني الإمدادي

\author{
إعداد \\ د/على عحمد غريب عبدالله \\ مدرس بكلية التربية بالوادى الجديد

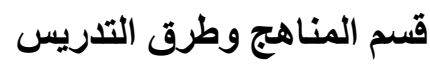 \\ (تخصص مناهج وطرق تدريس رياضيات)
}




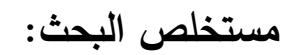

هدف البحث إلى التعرف على فاعلية استخدام نموذج تدريسى مقترح قائم على التعلم السريع فيى التى التحي

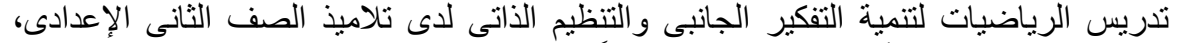

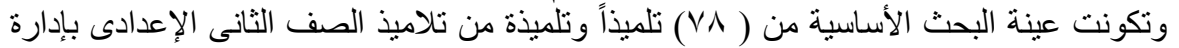

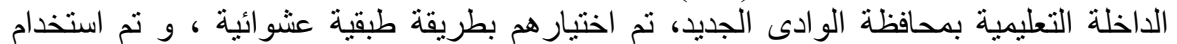

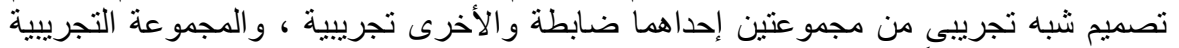

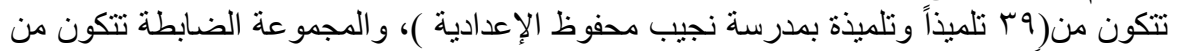

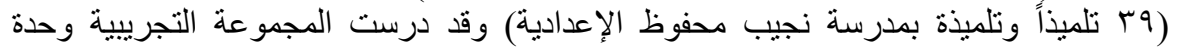

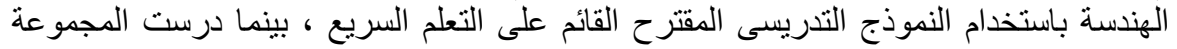

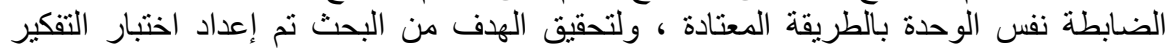

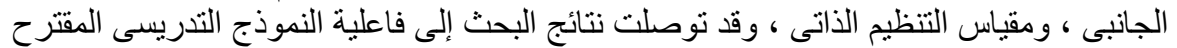

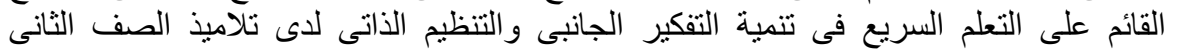

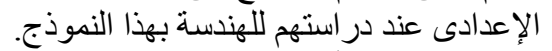

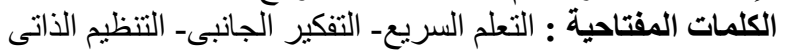

\section{Abstract Search}

The Current Research aimed to recognize the effectiveness of using proposal teaching model is based on the Accelerated Learning in teaching of mathematics for developing the lateral thinking and self- regulation the second grade students of preparatory, the Basic research sample consisted of 78 students from the second grade students of preparatory Dakhala educational administration in the New Valley Governorate, selected by a stratified random method, and the researcher used the design Quasiexperimental of two groups, one experimental and the other control, and the experimental group that contained (39) male and female students of school Naguib Mahfouz Preparatory) who studied using the proposed teaching model based on accelerated learning, and a control group consisting of (39) male and female students of school Naguib Mahfouz Preparatory who studied using according to the traditional method, and to achieve the aim of the research was the preparation of a test lateral thinking, and a scale of self-regulation, it has reached the search results to the effectiveness of the proposed teaching model based on Accelerated Learning in developing lateral thinking and self-regulation for the second grade students of preparatory when their studies of geometry this model.

Keywords: - Accelerated Learning - Lateral thinking - Self-regulation 


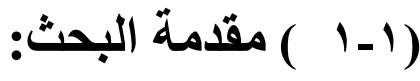

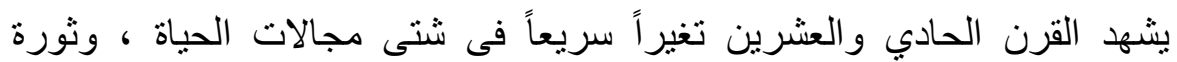

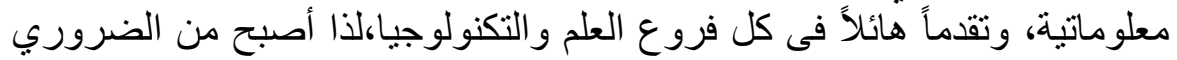

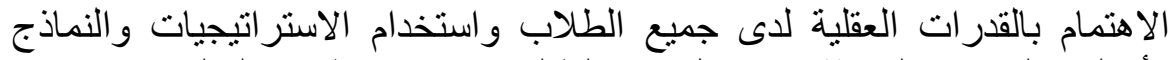
وأساليب التدريس الحديثة بما يجعل دور الطالب إيجابي نشط الطئ في التعليم.

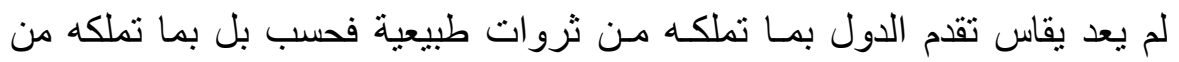

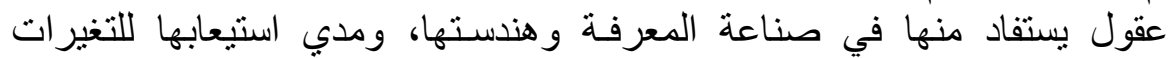

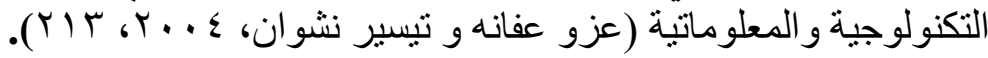

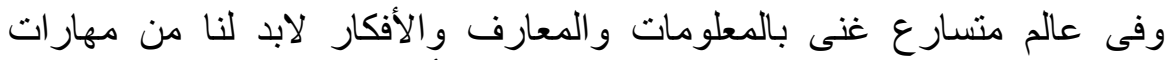

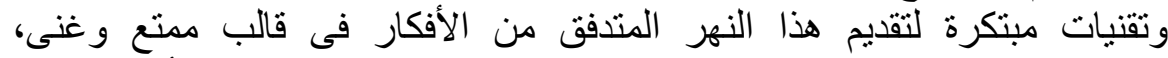
و المجتمعات لا تنهض و لا تتطور إلا بالتفكير والإبداع الذي بات بات من أبرز سمات العصر الحالي.

ويعد التفكير الجانبي أحد أساليب التفكير الذي يسهم في تغيير الأفكار والمفاهيم

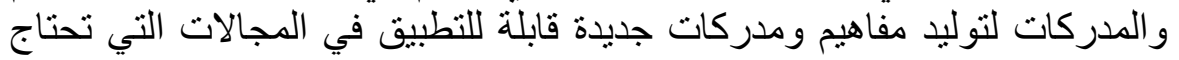

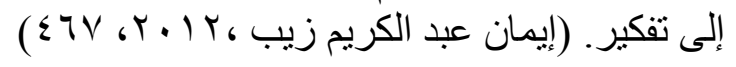

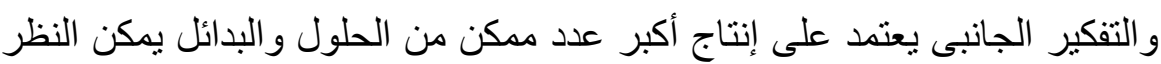

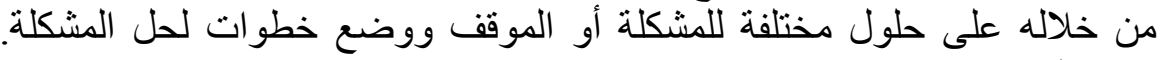

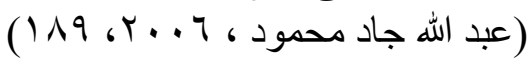

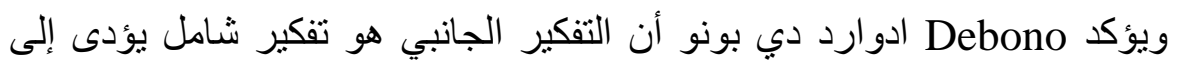

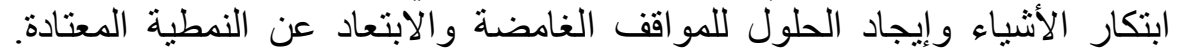

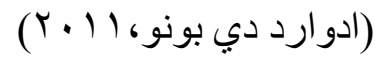

و ممارسة المتعلم لمهار ات التفكير الجانبي تجعله يفكر خارج حدود التفكير التقليدي

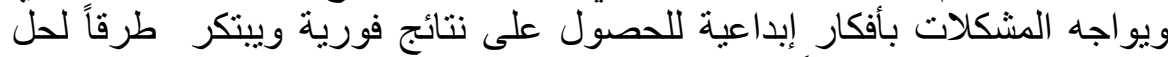

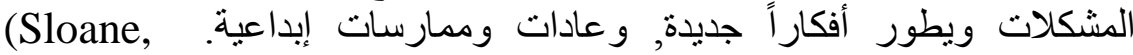
2003,53).

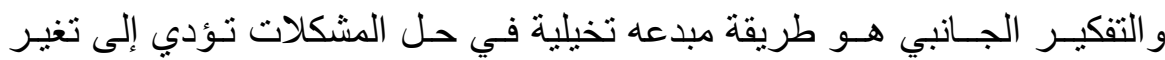

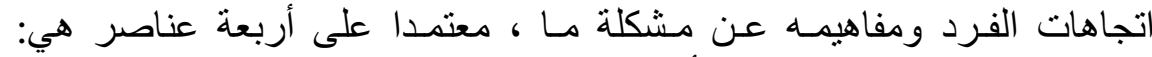

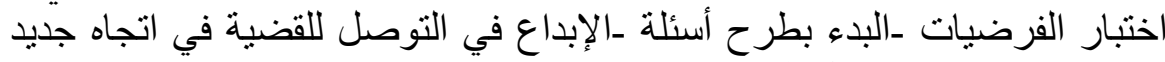

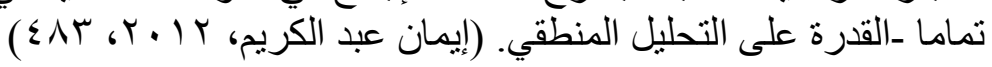


و تثنير الدراسات إلى أهمية التفكير الجانبى حيث يعد بالغ الأهمية في عملية التعلم

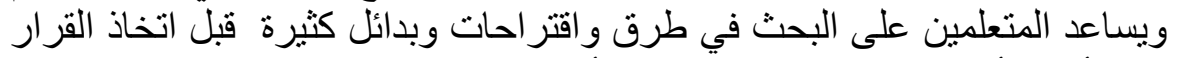

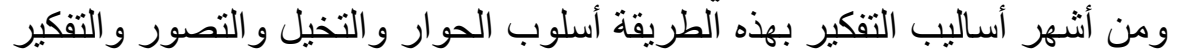
من زوايا متعددة. (Lawrence \& Xavier, 2013,28)

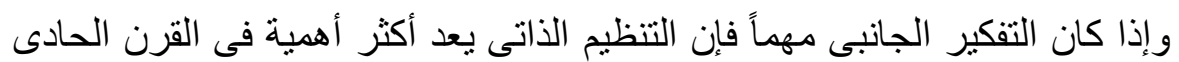

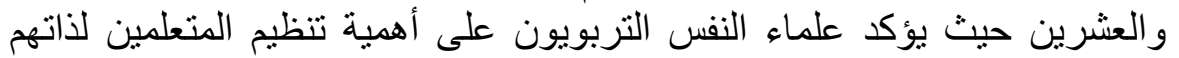
حيث يعمل على اكتساب المعرفة وتكاملها واسترجاعها. ) $(., 2009$

ويشير كين و كين Cain \& Cain في نظريته إلى أن الدماغ مزود فطرياً

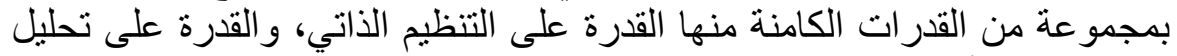

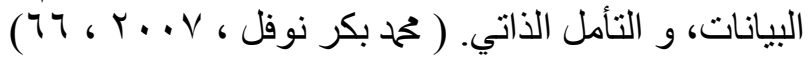

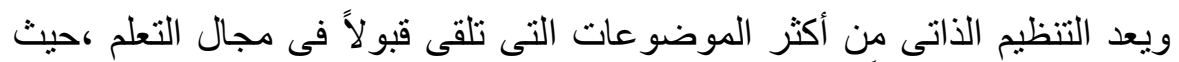

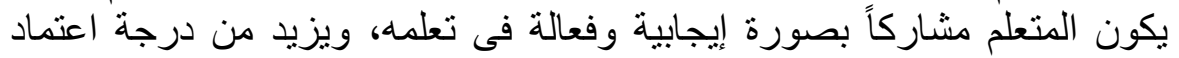
الطلاب على أنفسهم فى عملية التعلم (Vrgut,2008,12).

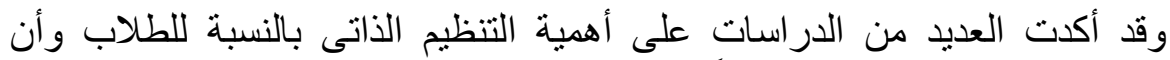

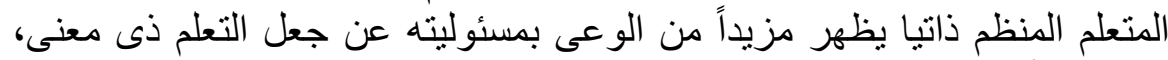

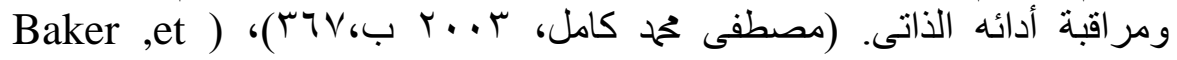
(al.,2009,303

فى ضوء ماسبق نجد أن الاهتمام بتنمية مهارات التفكير الجانبى والتنظيم الذاتى في التهري

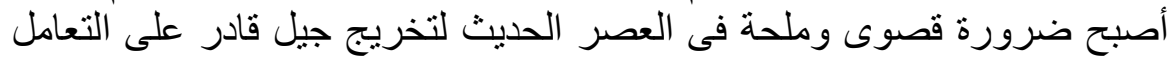
مع منغير ات العصر ومو اجهة مشكلاته وحلها. ومن هنا جاءت الحاجة إلى استخدام طرق وأساليب ونماذج حديثة فى التدريس تعمل على تنمية التفكير الجانبى و التنظيم الذاتى لدى التى التلاميذ.

ويمثل التعلم السريع أحد الأساليب الحديثة للتعلم؛ حيث يقدم تصور اً جديداً لاستثمار

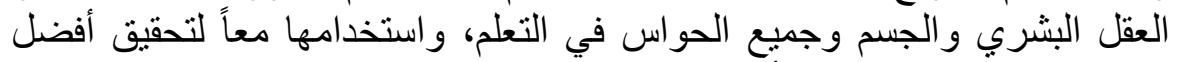

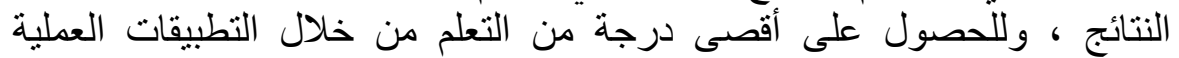

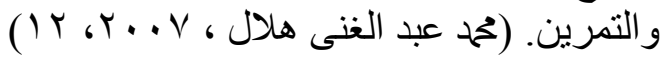

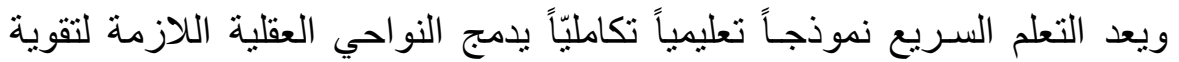

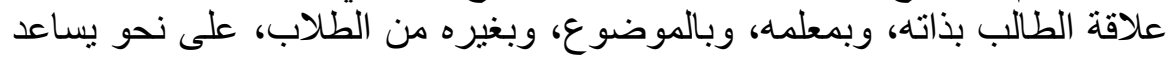


الطلاب على تحقيق إنجاز تعليمي أكثر عمقًا. (فاطمة بنت مطلق معيش

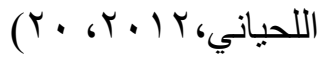

ونتيجة لذلك يتم استخدام نموذج تدريسى مقترح قائم على التعلم السريع وسوف يتم

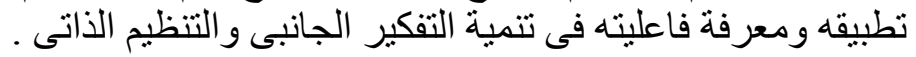

\section{(Y-1)}

\section{الإحساس بالمشكلة :نبعت مشكلة البحث مما يليح:}

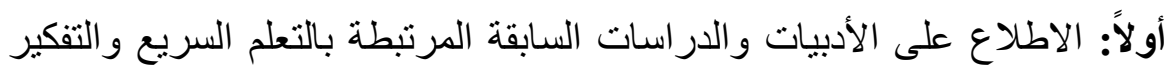

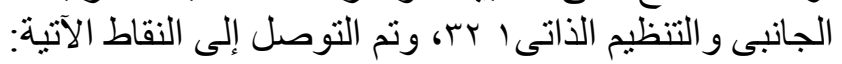

• أهمية استخدام التعلم السريع على تحقيق العديد من التطبيقات التربوية المهرة

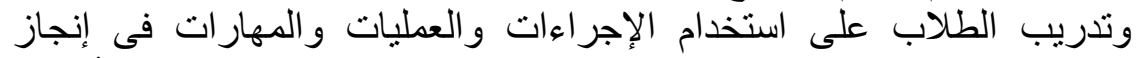

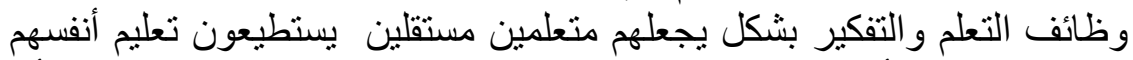

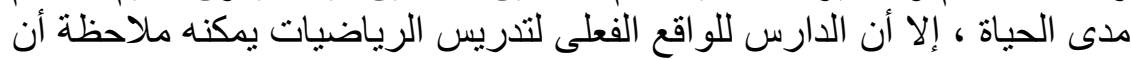

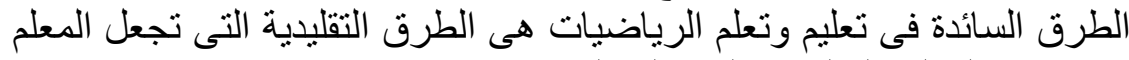

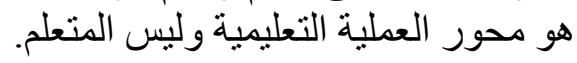
• أهمية تتمية مهار ات التنظيم الذاتى لدى تلاميذ المرحلة الإعدادية فى تطوير ولثير

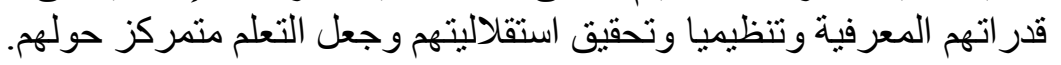

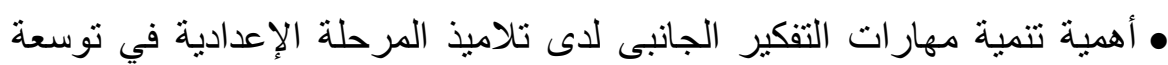

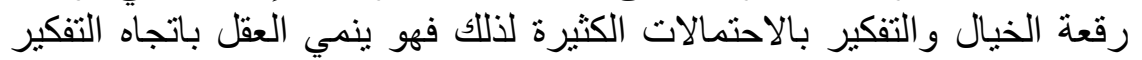

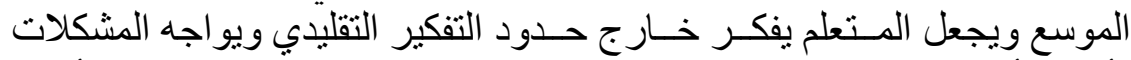

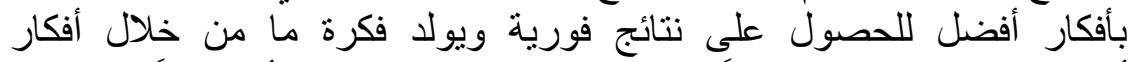

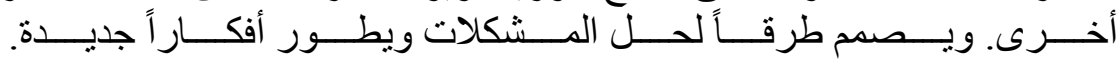

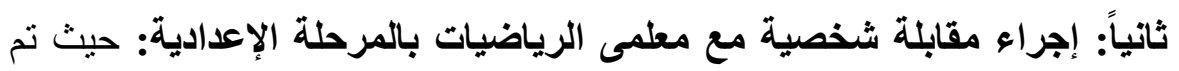

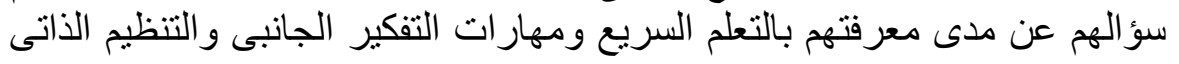

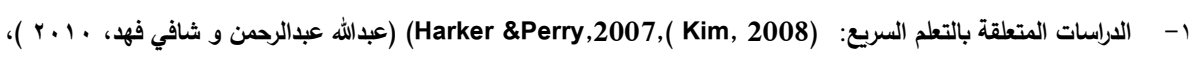

Tomas, 2013). (

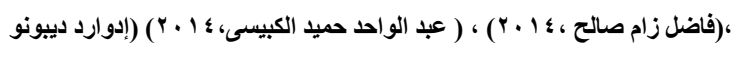

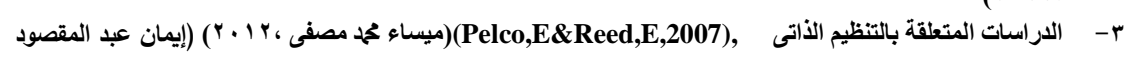

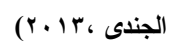


وتدريب طلابهم عليها، فاتضح من إجاباتهم أن معظمهم ليس لديه معرفة بالتعلم

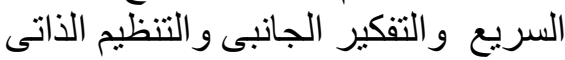

ثالثاً: إعداد اختبار للتفكير الجانبى فى الرياضيات وتطبيقه على عينة استطلاعية

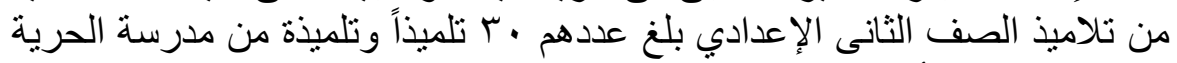

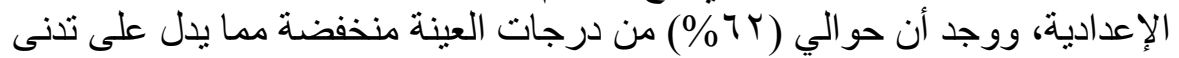
مهار ات التفكير الجانبى لدى معظم هذه العينة .

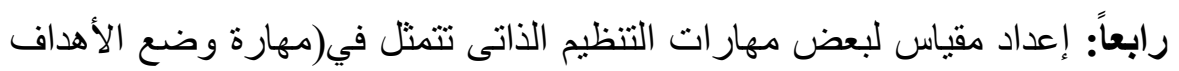

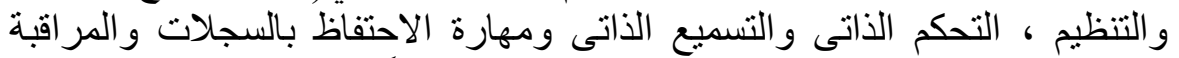

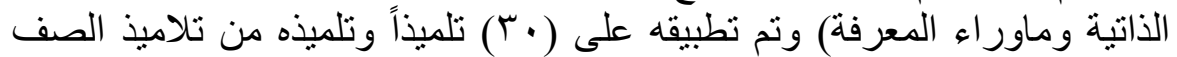

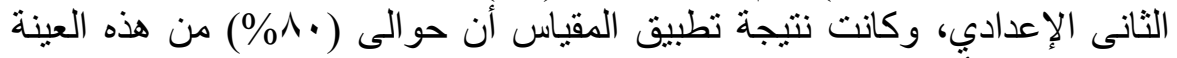

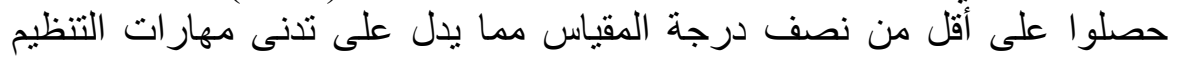
الذاتى لديهم .

و عند النظر إلى واقع تدريس الهندسة في مدارسنا نجد أنه لا زال يعانى من التركيز

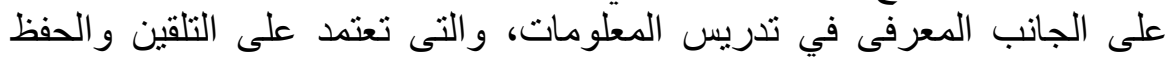

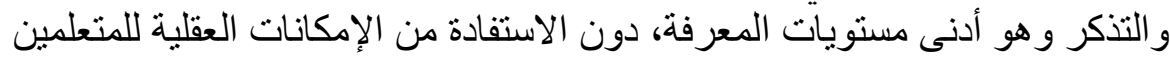

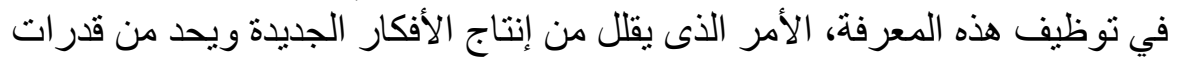

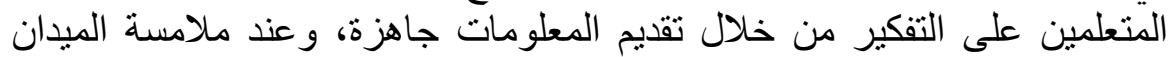

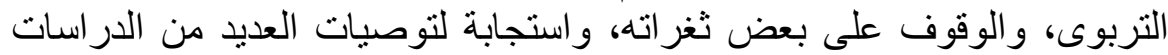

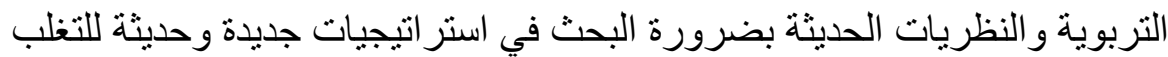

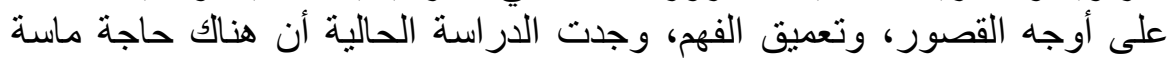

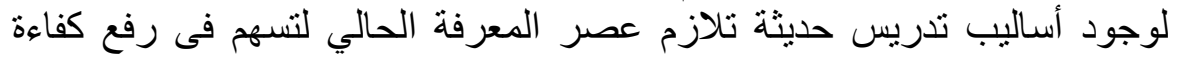
التلاميذ.

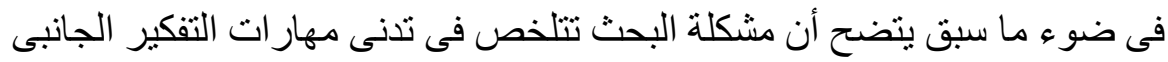

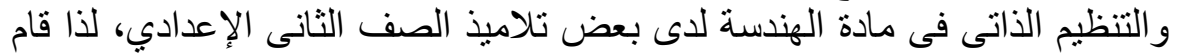

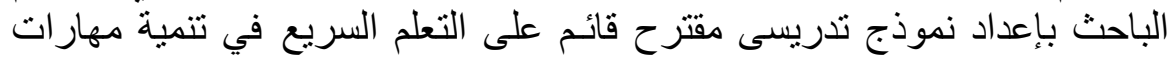

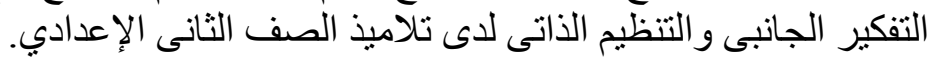

وللتصدى لهذه المشكلة يحاول البحث الحالى الإجابة عن السؤال الرئيس التالى التي: ما فاعلية نموذج تدريسى مقترح قائم على التعلم السريع في تتمية مهار ات التهى التفكير الجانبى و التنظيم الذاتى لدى تلاميذ الصف الثي الثانى الإعدادي؟ ويتفرع عن هذا السؤ ال الأسئلة الفرعية التالية: 


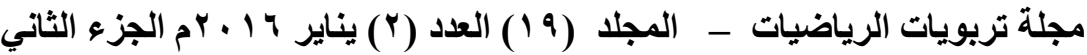

1. ما النموذج التدريسى المقترح القائم على التعلم السريع فى الهندسة لتلاميذ الإيذ

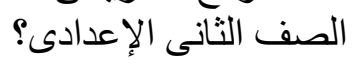

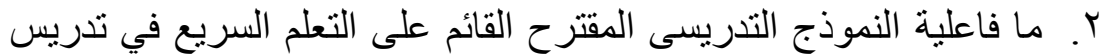

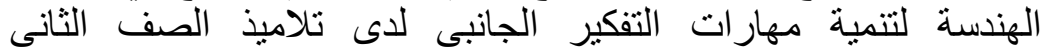

$$
\text { الإعدادي؟ }
$$

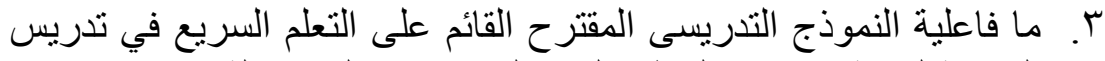

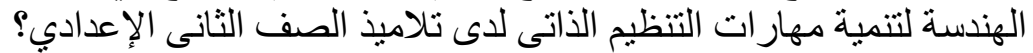

$$
\text { ( ـ ( ع أهداف البحث: }
$$

$$
\text { هدف البحث الحالي إلى : أهنى }
$$

I ـ تصميم نموذج تدريسى قائم على التعلم السريع .

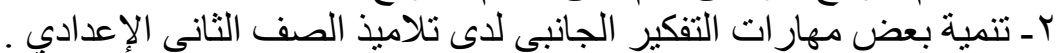

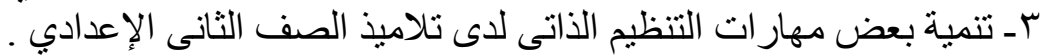

\section{: أهمبة البحثة}

\section{تتمثل أهمية البحث الحالى فيما يلى إن:}

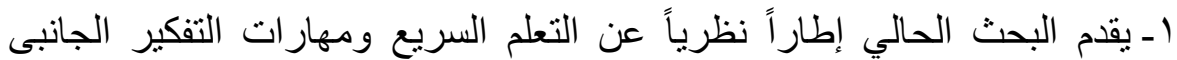
و التنظيم الذاتى يمكن أن يفيد معلمى الرياضيات بالمن بالمرحلة الإعدادية .

r- يساعد البحث الحالي مخططى المناهج على كيفية تضمين مبادئ التعلم السريع

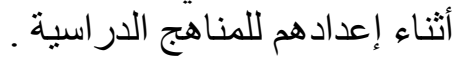

r- يقدم البحث الحالى نموذجا تدريسياً منسجم مع الطريقة التى يتعلم بها الإنسان . بهان بشكل طبيعى .

ع - يقدم اختبار في مهارات التفكير الجانبى ، ومقياس في مهارات التنظيم الذاتى

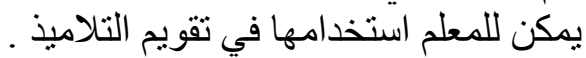

هـ قد تكون نتائج البحث مفتاحاً لتدريب المعلمين على تنمية التفكير الجانبى وتنظيم

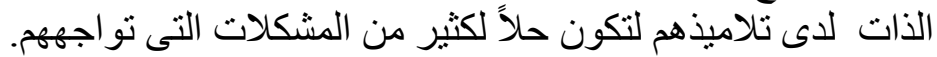

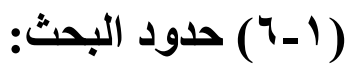

ا - وحدة الهندسة المقررة على تلاميذ الصف الثانى الإعدادي الفصل الإدان الدراسي

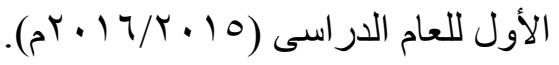




\section{مجلة تربويات الرياضيات - المجلد (9 1) العدد (Y) يناير 17 ـ ب م الجزء الثاني}

r- مجموعة من تلاميذ الصف الثاني الإعدادي ببعض مدارس إدارة الداخلة التعليمية ـ محافظة الو ادى الجديد محل إقامة الباحيث.

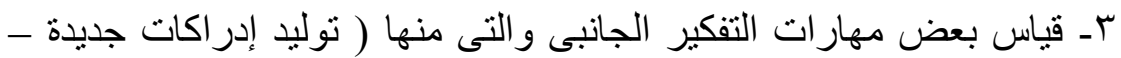
توليد مفاهيم جديدة - توليد أفكار جديدة - توليد بدائل جديد التيدة - توليد ليد إبداعات

جديدة )

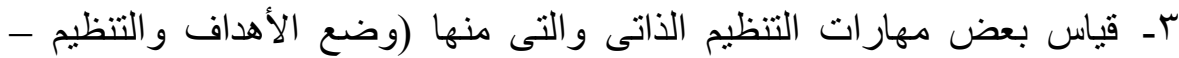

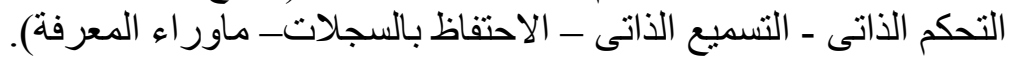

$$
\text { مواد وأدوات البحث: (V- ) }
$$

قام الباحث بإعداد المو اد و الأدوات التوات التات

$$
\begin{aligned}
& \text { - مو اد تعليمية تمثلت في : }
\end{aligned}
$$

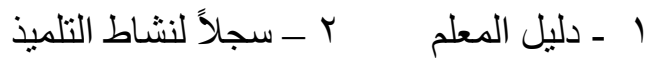

ـ أدوات قياس تمثلت فى: اختبار التفكير الجانبى ـ مقياس التنظيم الذاتى للتعلم .

$$
\text { (A- ) منهج البحث: (1) }
$$

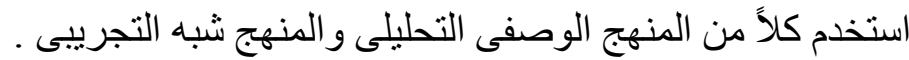

ا ـ المنهج الوصفى التحليلى: لاستقر اء الأدبيات و الدر اسات السابقة بمتغير ات التهيه البحث.

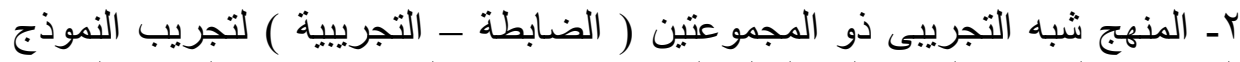

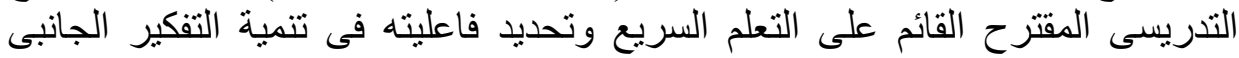

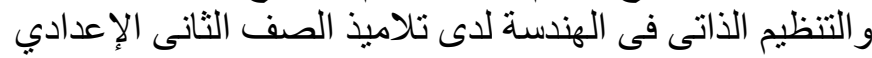

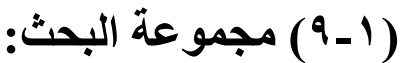

تم اختيار مجمو عة من تلاميذ الصف الثانى الإعدادى بمدارس إدارة الداخلة التعليمية وتم تقسيمهم إلى مجمو عنين :

- المجمو عة التجريبية : عددها وب تلميذاً وتلميذة من مدرسة نجيب محفوظ الإعدادية

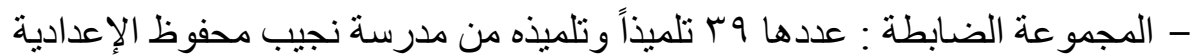

$$
\text { (1 - - (1) فروض البحث: }
$$

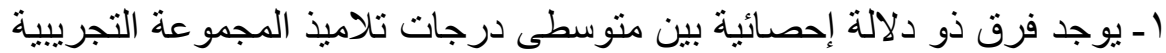

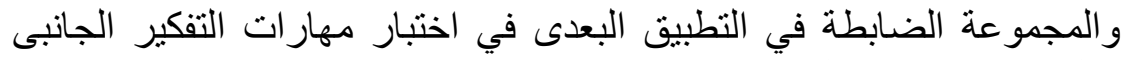

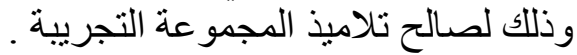


Y - يوجد فرق ذو دلالة إحصائية بين متوسطى درجات تلاميذ المجمو عة التجريبية في التطبيقين القبلى و البعدى في اختبار مهار ات التفكير الجانبى وذلك لصنات لصالح

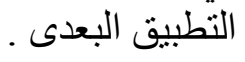

r - يوجد فرق ذو دلالة إحصائية بين منوسطى درجات نلاميذ المجمو عة التجريبية و المجموعة الضابطة في التطبيق البعدى في مقياس التنظيم الذاتى للتعلم وذلتل دئل

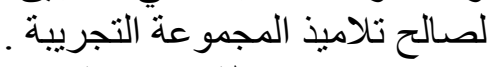

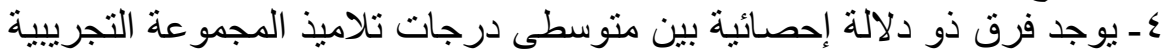

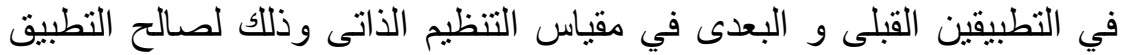

$$
\text { البعدى . }
$$

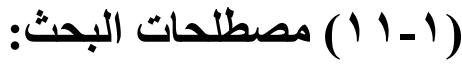

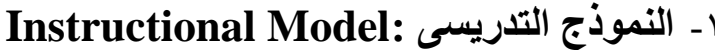

هو خطة توجيهية تعتمد على نظرية تعلم معينة ،و مجمو علة نو نواتج و وإجر اءات مسبقة

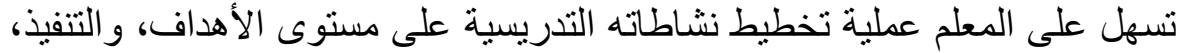

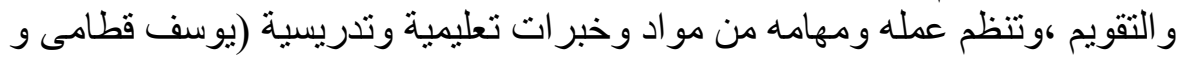

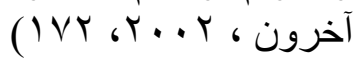

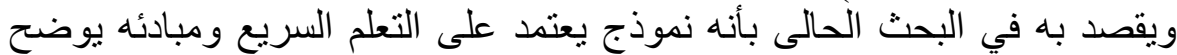

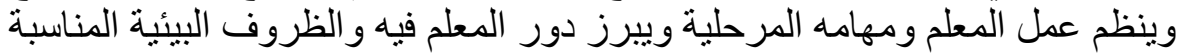
و الحافزة لبيئة التعلم.

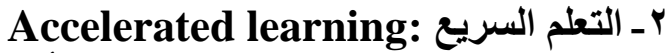

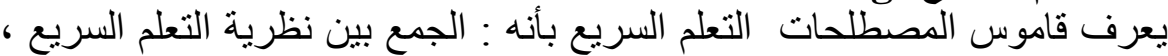
وأبحاث الدماغ فى بيئة تعلم إيجابية ، لتحقيق أسرع معدل نمو. Glossary of

(Terms ,2014)

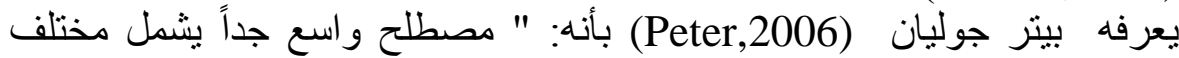

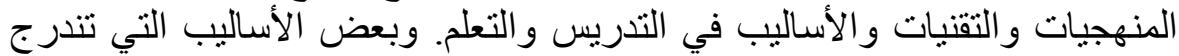

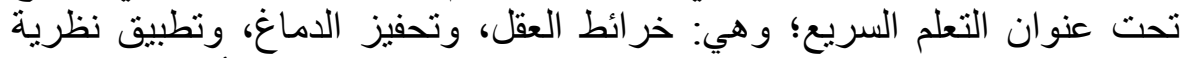

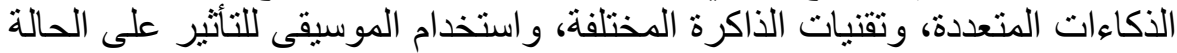

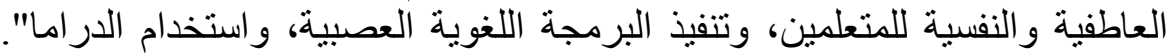

ويقصد به فى البحث الحالى ذلك التعلم المستند إلى مبادئ التعلم السريع ،و أسلوب يتم

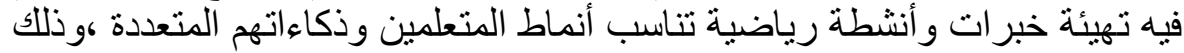

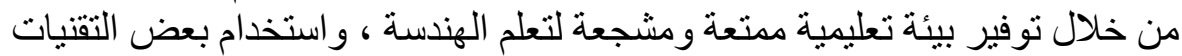
التربوية الحديثة التى تجعل التعلم مثتع وأسر ع فى تدريس الهندسة. 


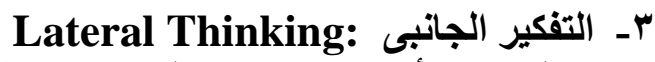

و عرفه الكبيسي بأنه تفكير يتميز بالبحث و الانطلاق بحرية في اتجاهات متعددة بدلا

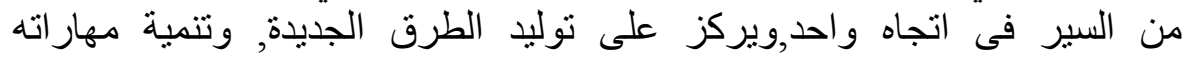

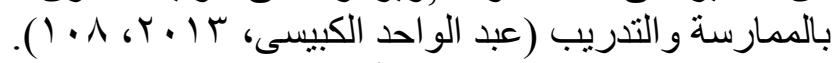

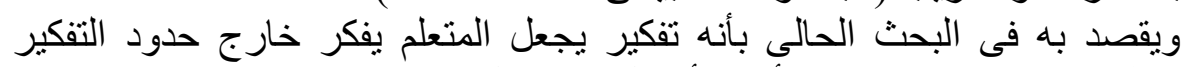

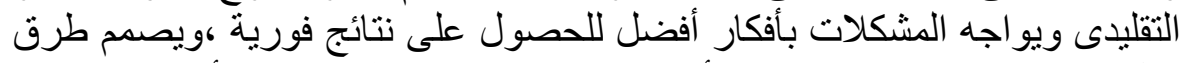

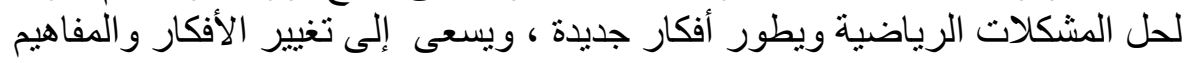

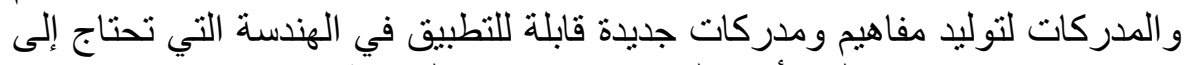

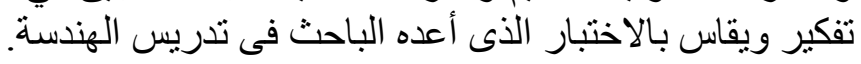

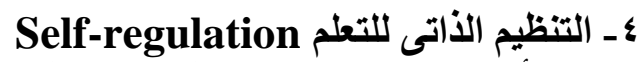

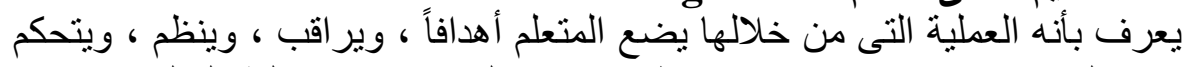

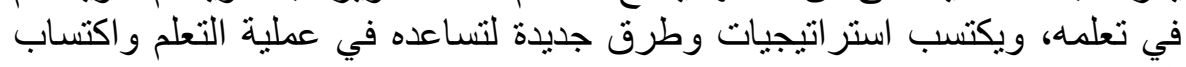
المعرفة (Bembenutty,2006,223)

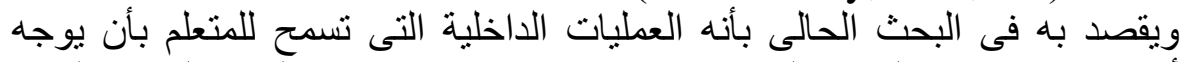

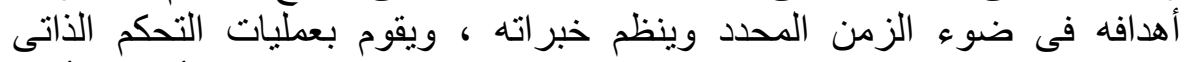

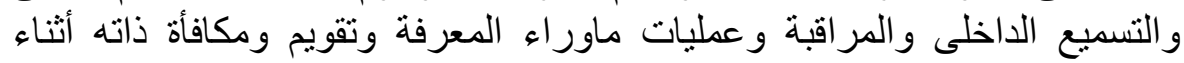
در اسة مادة الرياضيات.

\section{(Y) (الإطار النظري للبحث}

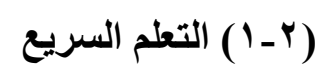

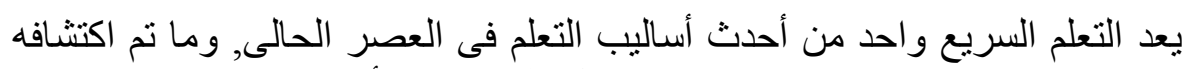

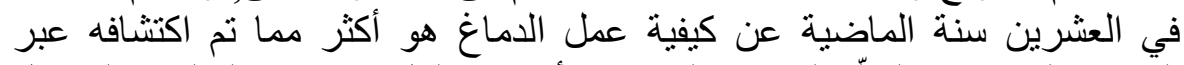

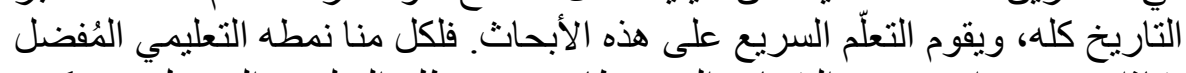

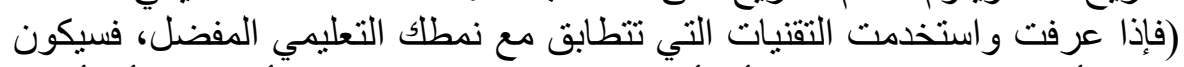

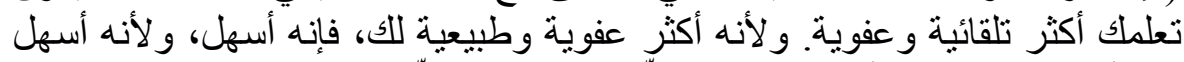

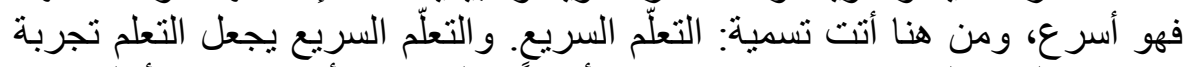

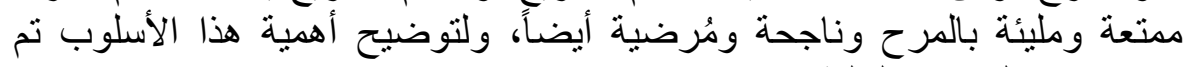
عرضه في المحاور التالية:

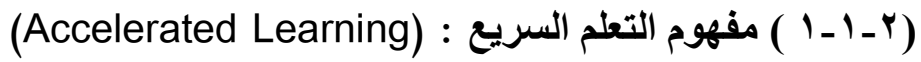

التعلم السريع هو الترجمة العربية لعبارة (The Accelerated Learning) في اللغة الإنجليزية، والتي تعني حرفياً "التعلم المُسرَّع". يقوم المفهوم الأساسي للتعلم 


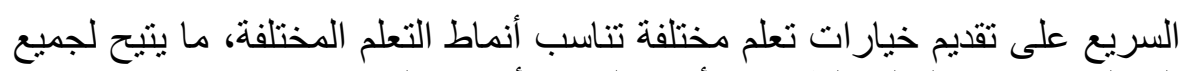

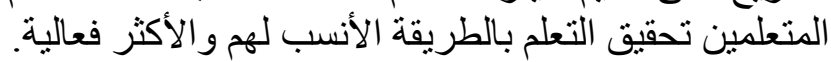

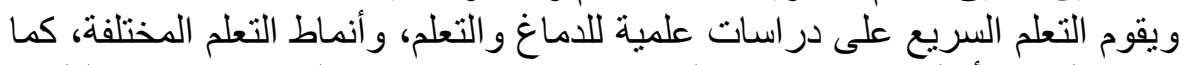

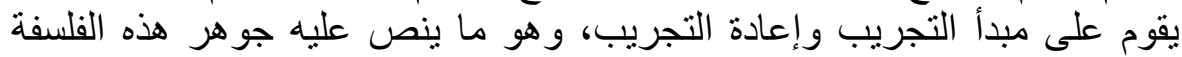

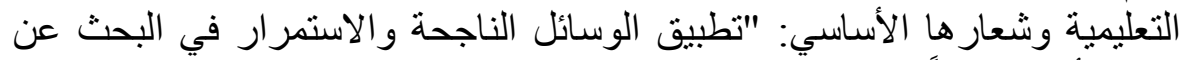
وسائل أكثر نجاحاً". (Pienaar, 2008,5)

والتعلم السريع هو نموذج يستخدم مجموعة من الأنشطة العلمية، صممت بطريقة

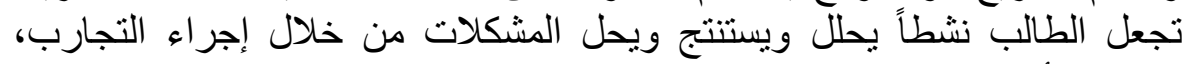

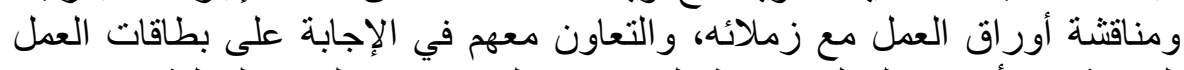

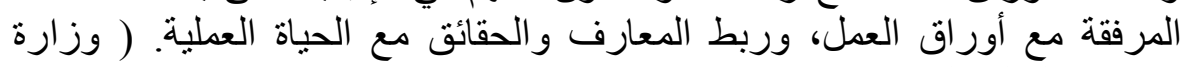

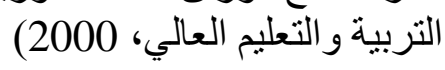

ويعرفه ( 2007,42, Boyd) بأنه نموذج متعدد الأبعاد يعتمد على التجربة العملية أكثر من التلقين و المشاركة الفعالة والنشطة للمتعلمين.

وتؤكد دراسة (Ganiron,2013) أن التعلم السريع يساعد التلاميذ على المشئ ونساركة

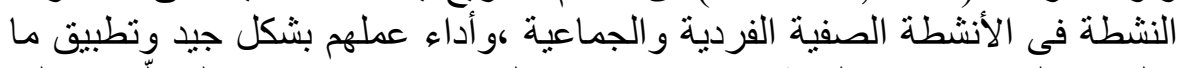

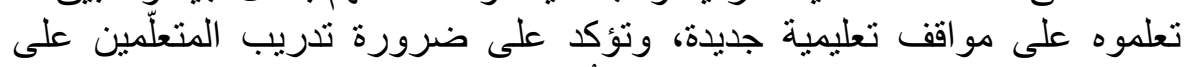

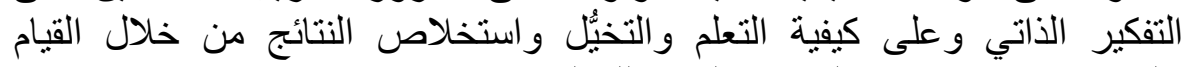
بالتجارب و الآبتعاد عن التخزين البنكي للمعلومات.

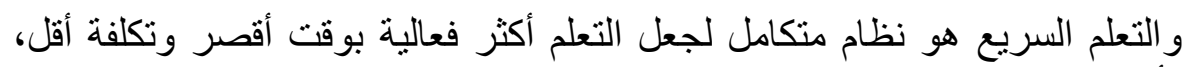

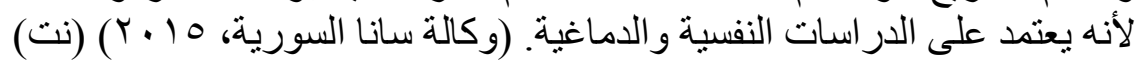

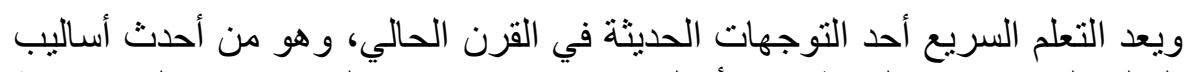

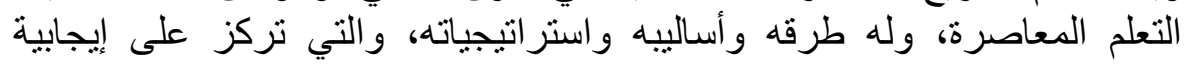

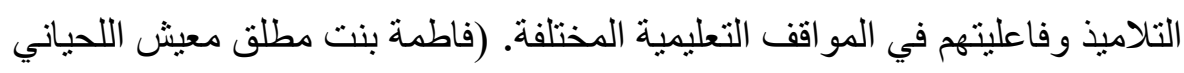

$\left(17 . r_{0}\right) r_{6}$

ويظهر من التعريفات السابقة إجماع المربين على أن التعلم السريع يشترك في: - يركز على إثر الك الطلاب (جسدًا، و عقلاً، ومشاعراً) في عملية التعلم.

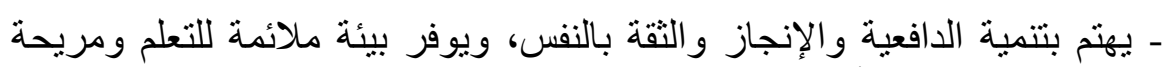

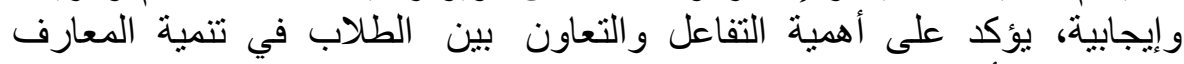

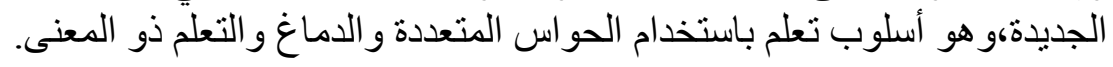




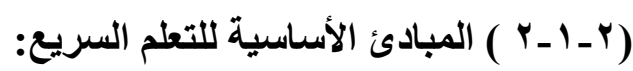

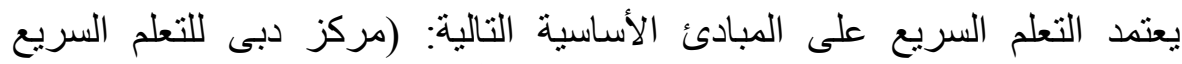

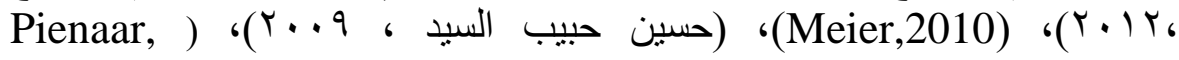
(2008,29

اـ البيئة الإيجابية : يتعلم التلاميذ بشكل أفضل في بيئة صحية, مادياً وعاطفياً

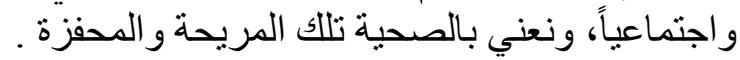

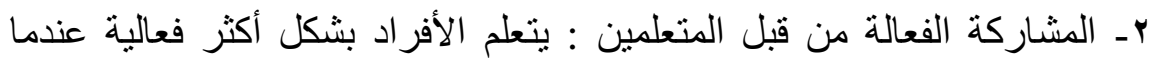

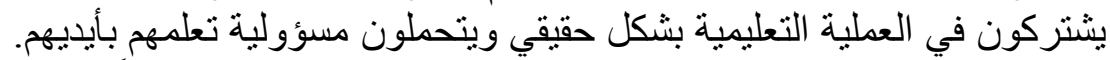

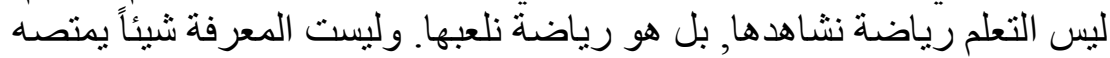

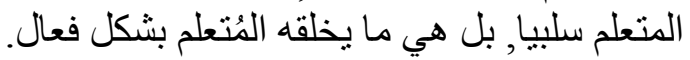

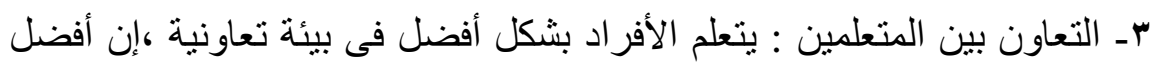

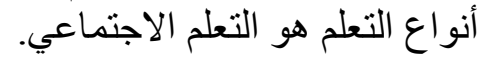

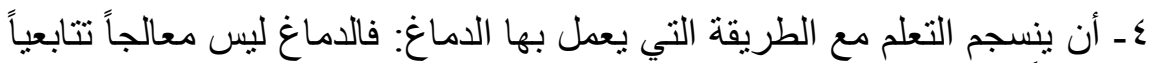

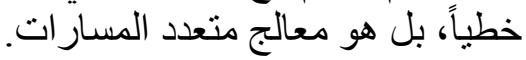

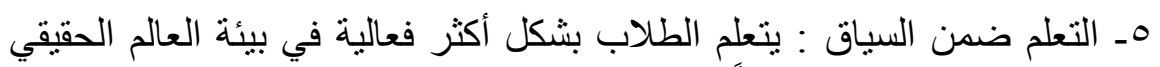

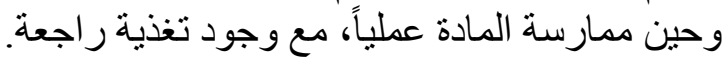

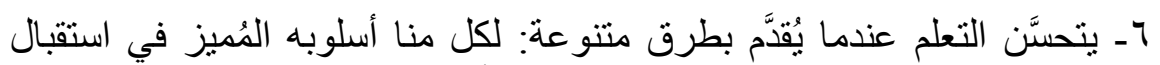

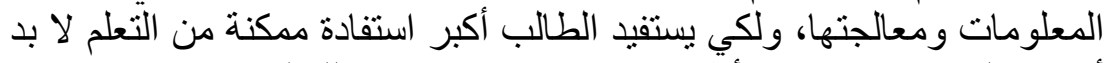

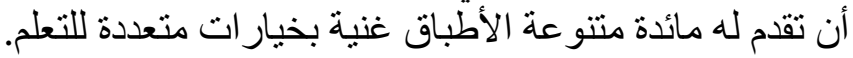

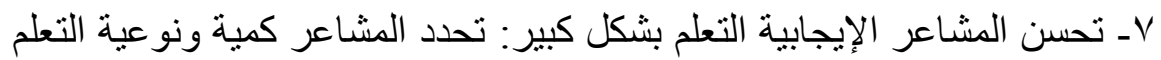

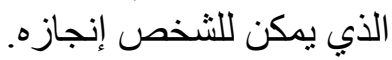

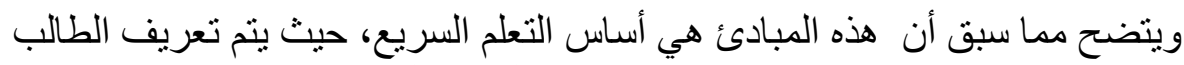

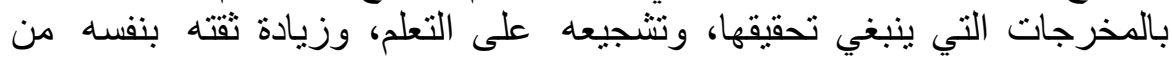

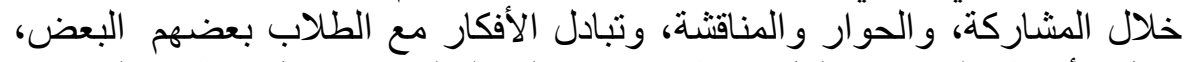

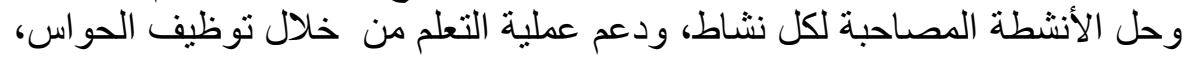

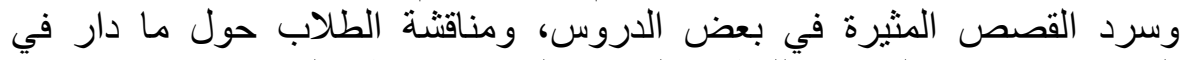

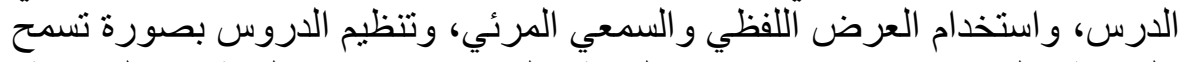

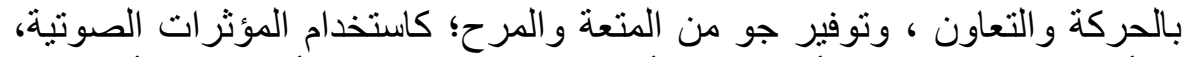

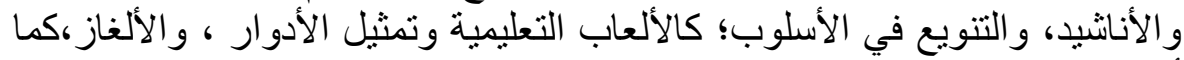

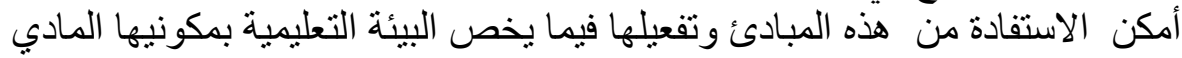
والنفسي 


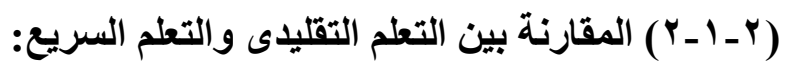

مقارنة بين التعلم التقليدى و التعلم السريع (Swenson, 2003 )، (Silliams, (

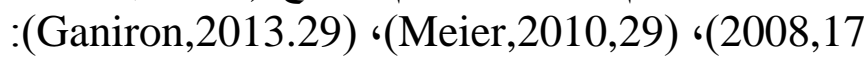

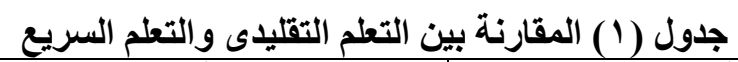

\begin{tabular}{|c|c|}
\hline يميل التطلم السريع لأن يكون & يميل التعلم التقليدى لأن يكون \\
\hline مرناً مرنا & صلبا \\
\hline تعاونياً ، إنسانياً ، متعدد الحواس . & تنافسيا ،سلوكياً ، شفهياً ، متحكماً \\
\hline متعدد الاتجاهات & ذا اتجاه واحل \\
\hline مركزأ على النشاطات & مركزا على المواد \\
\hline التركيز على المتطلم & التركيز على المعلم \\
\hline 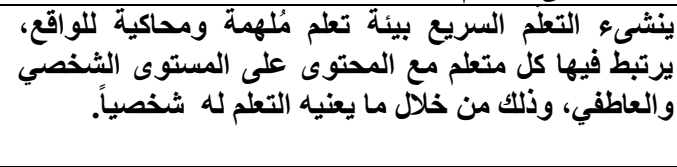 & 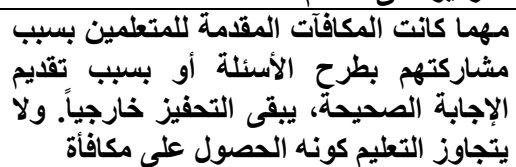 \\
\hline 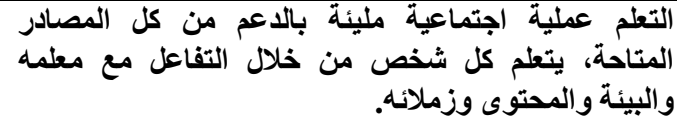 & القاعة حيث يقت المدلقى المطلومات من مقامة \\
\hline
\end{tabular}

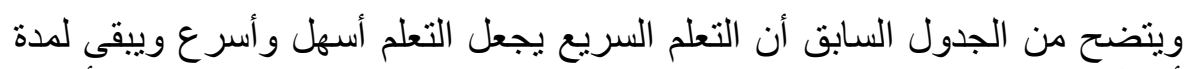

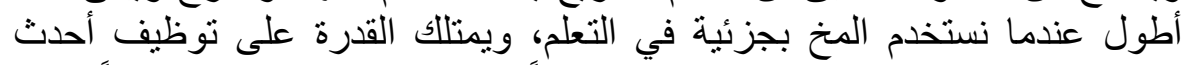

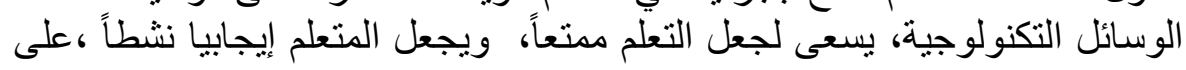
عكس التعلم التقليدى.

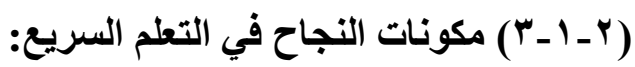

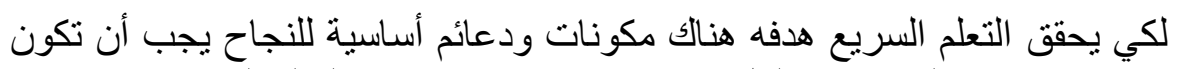

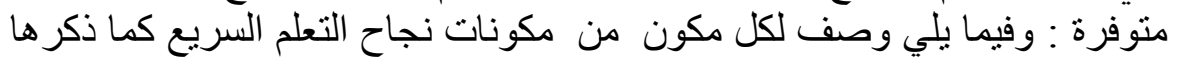

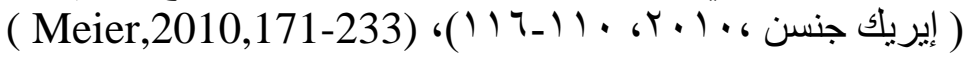

$$
\text { أولا:ً استعداد الطالب وتكيفه: }
$$

معلم التعلم السريع يفترض أن الطالب يحمل في داخله مشاعر سلبية تحول دون دون

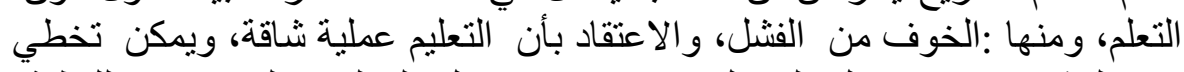

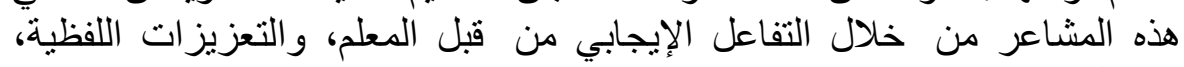

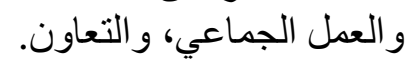

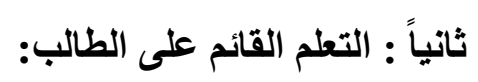

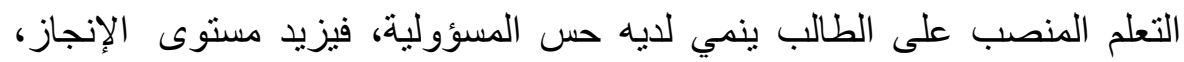

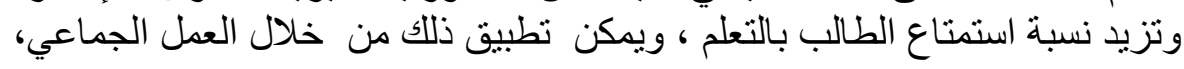


ومطالبتهم بابتكار لعبة متوافقة مع هذه المادة، أو تمثيل الأدوار، وتوفير روح

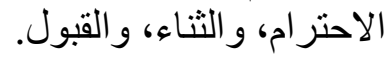
ثالثاً : توظيف المشاعر:

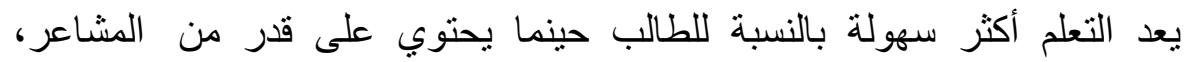

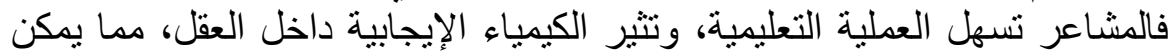

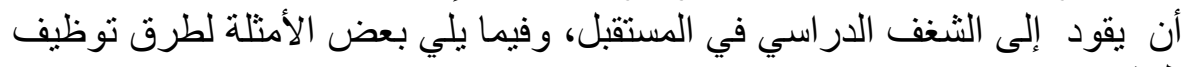
المشاعر:

$$
\text { ـ ـ المسر ح و التمثيل ـ الأناشيد ـ الألعاب القائمة على التعاون. }
$$

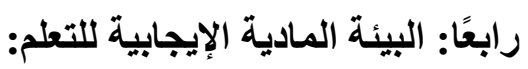

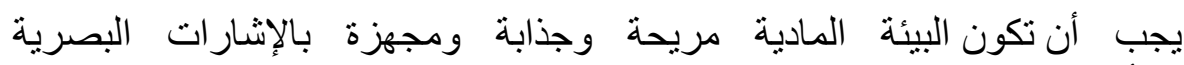

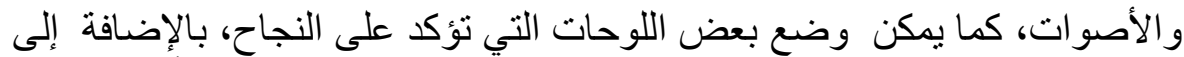

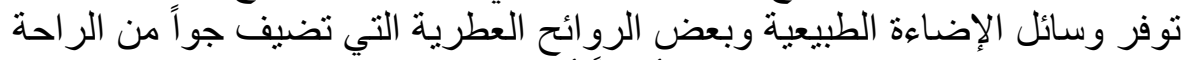

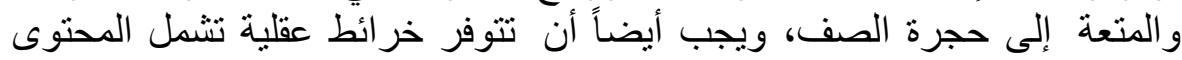

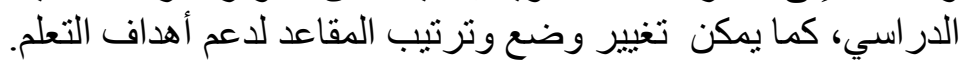

\section{خامساً : الإيحاعات الإيجابية:}

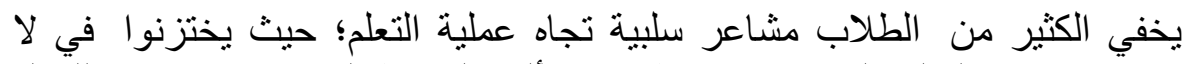

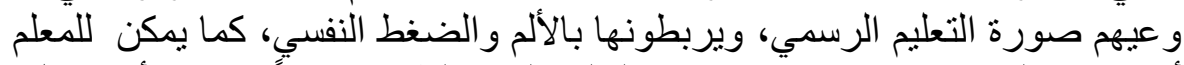

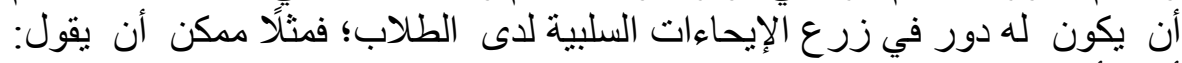

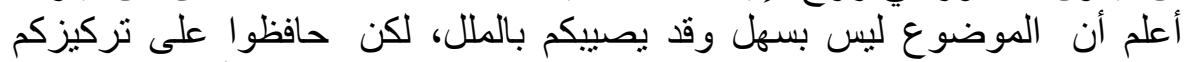

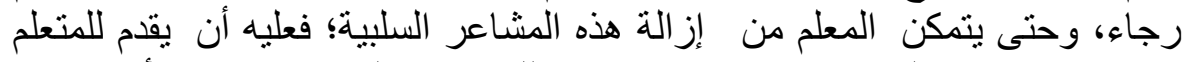

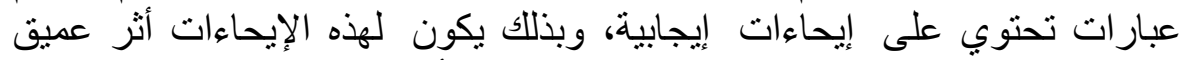

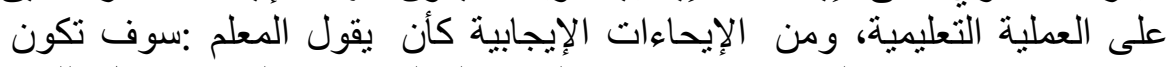

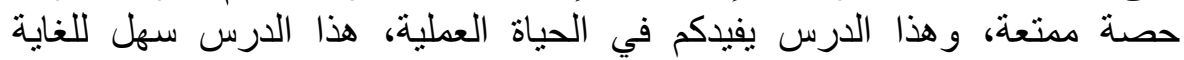

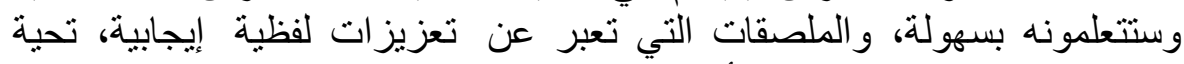

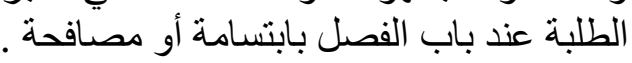

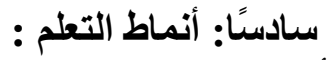

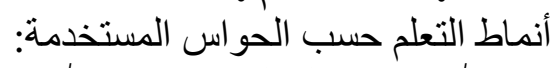

ل لمط التعلم السمعي. ل لمط التعلم الفكري. ل ل نمط التعلم البصري. 


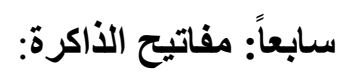

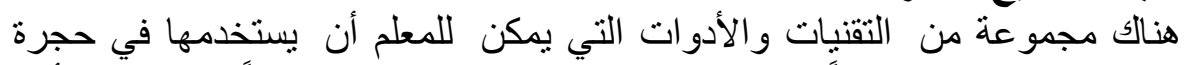

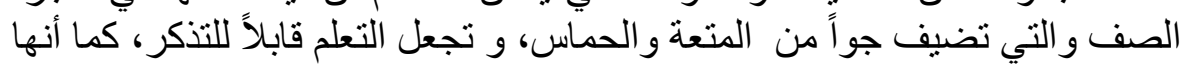

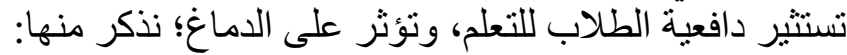

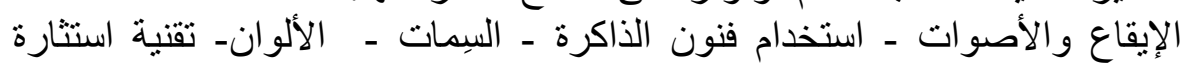

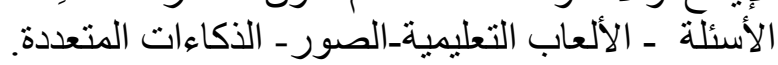

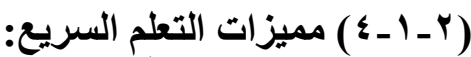

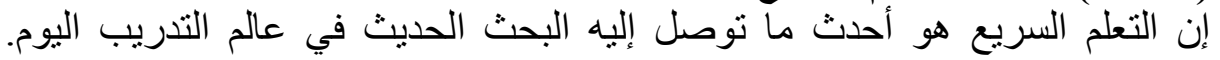

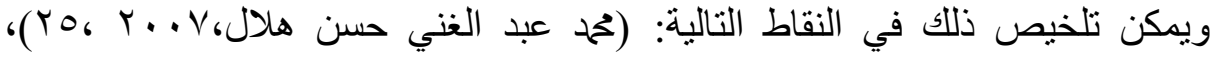

(Meier,2010,18) (Richards,2009,11), (Serdyukov,et al , 2005,23) - يمتلك القدرة على توظيف أحدث الوسائل التكنولوجية.

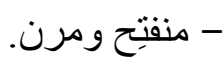

- يضمن مشاركة المتعلمين الفعالة في العملية التعليمية. - يزيد الحيوية في عملية التعلم ويعيد إليها إنسانيتها. - يسعى لجعل التعلم مرناً.

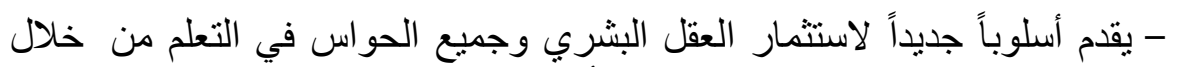
التطبيقات العملية والتمارين لتحقيق أفضار التضل النتائج.

- تهيئة مناخ تعليمي صحي ومناسب لسر عة اكتساب المعرفة.

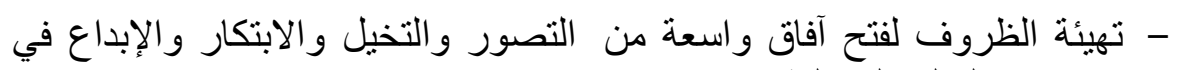

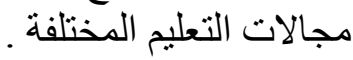

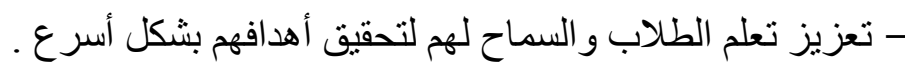

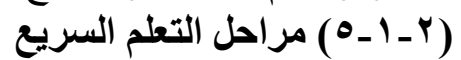

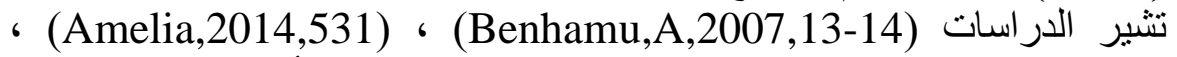
(Smith et al., 2010, 105)، (Meier,2010,107)

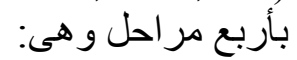

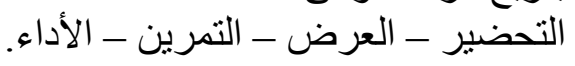
و هى مر احل متكاملة ومنر ابطة مع بعضها البعض وضئ ويمكن تمثيلها فى الثكل التالى: 


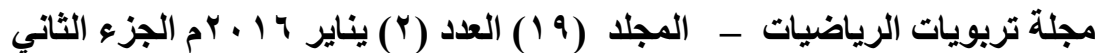

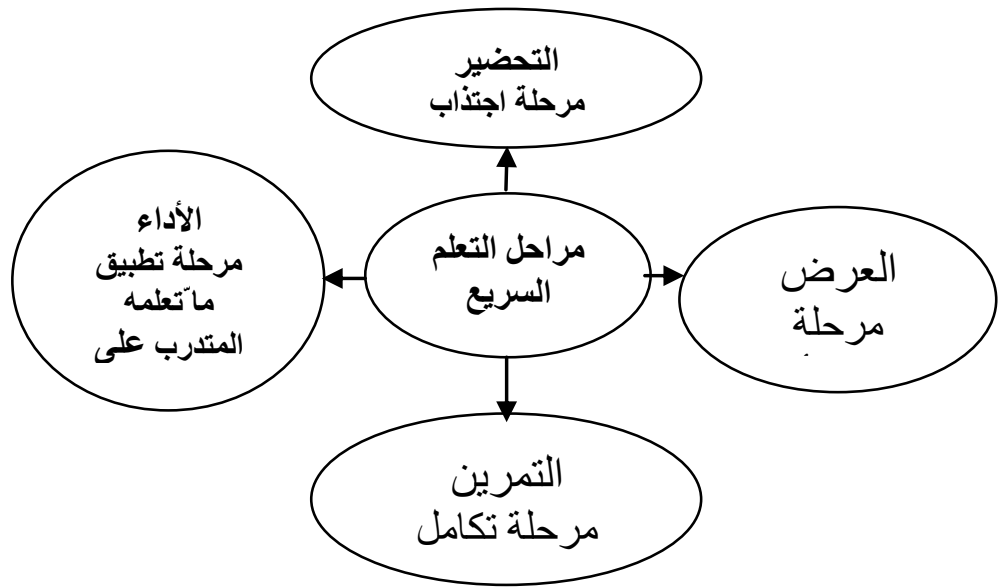

من خلال الثكل السابق نجد أن التعلم السريع عبارة عن حلقة دائرية منر ابطة تتكون

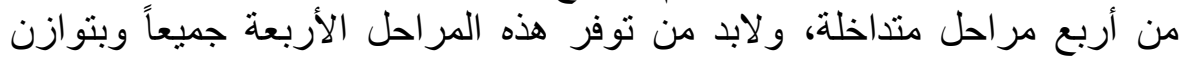

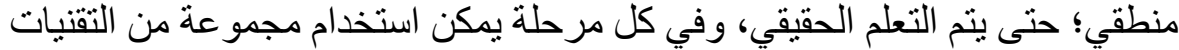

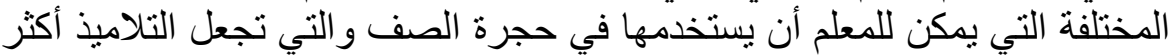
تفاعلاً في العملية التعليمية.

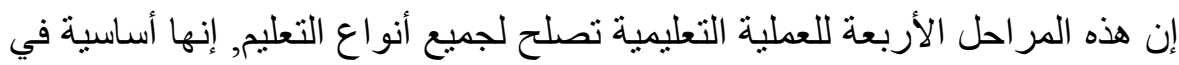

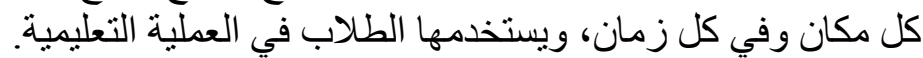

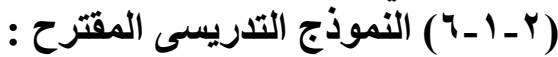

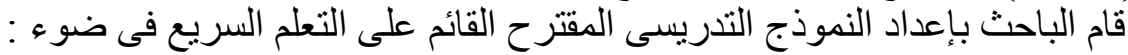

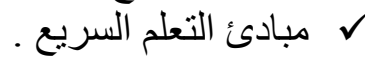

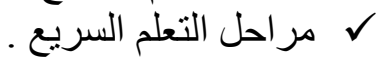
$\checkmark$ ل أهداف تدريس الرياضيات للمرحلة الإعدادية الرعادية مراحل النموذج المقترح: يتكون النموذج التدريسى المقترح حلثر من خمس مر احل أساسية هى :

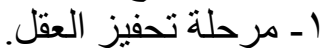

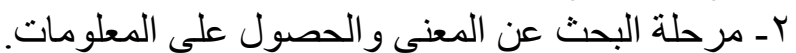
r- مرحلة التفكير النشط و القر اعن اءة السريعة. ع - مرحلة المعالجة السريعة. ــ مرحلة تطبيق التفكير السريع. 


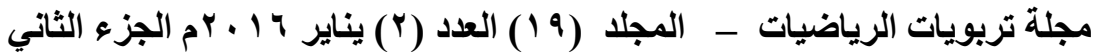

وتتنتمل كل مرحلة من هذه المراحل على عملية التقويم التكوينى والتخذية

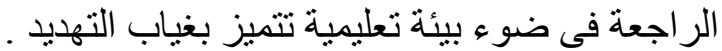

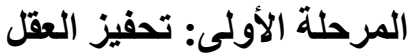
إثارة اهتمام التلاميذ, و إعطاؤهم مشاعر إيجابية, وجذب انتباه التباه الطلاب نحو التعلم. يتم تحقيق ذلك من خلام التها ما يلي:

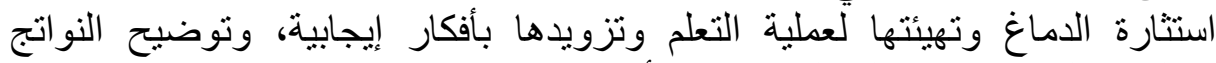

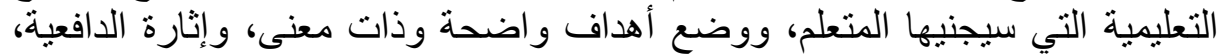

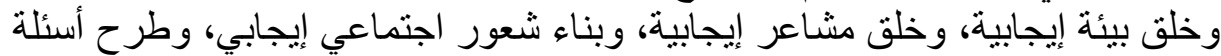

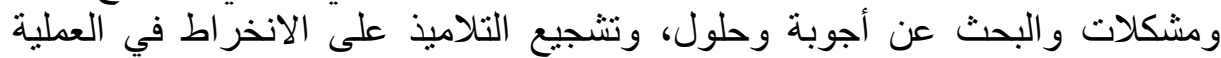

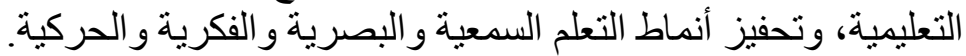

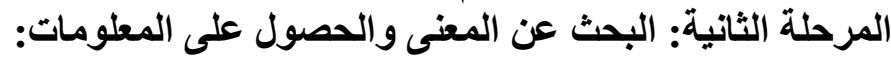

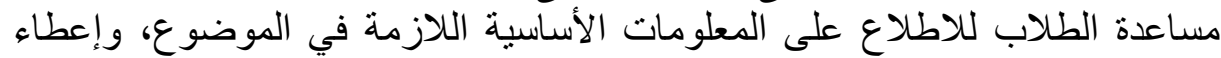

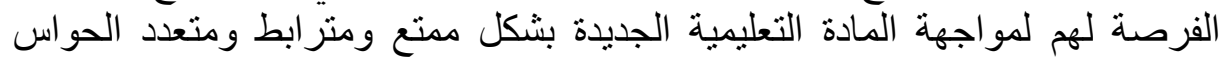

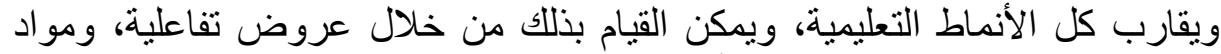

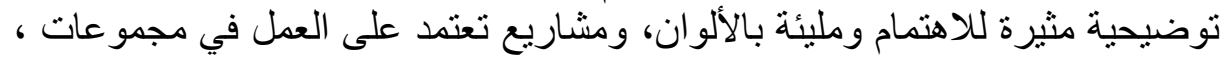

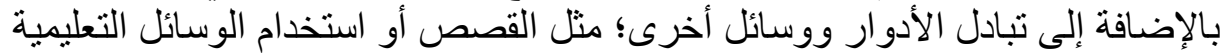

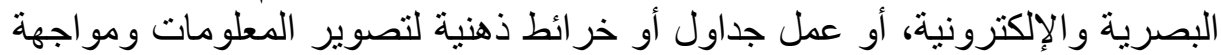
الطلاب ببعض التحديات.

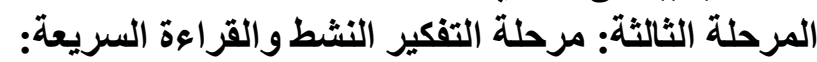

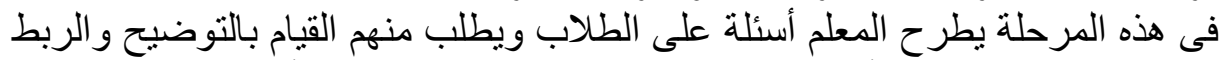

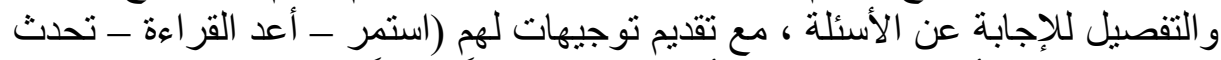

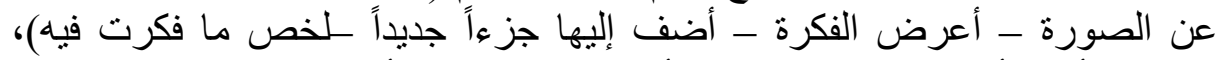

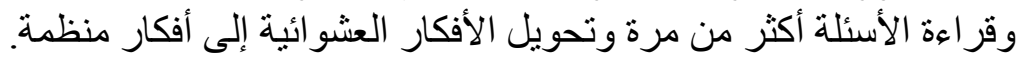
المرحلة الرابعة: المعالجة السرة السريعة: تشجيع التلاميذ على توسيع المعابل المعرفة واستيعاب المعرفة الجديدة وربطها بالخبرات

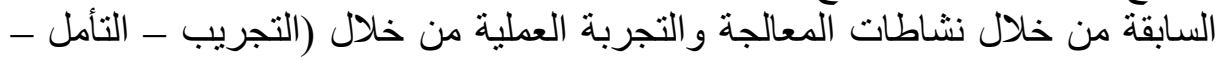

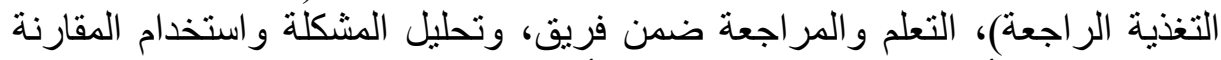

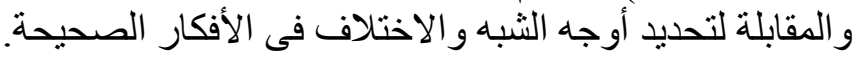

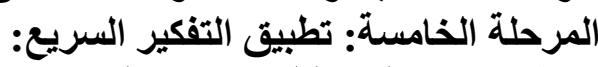

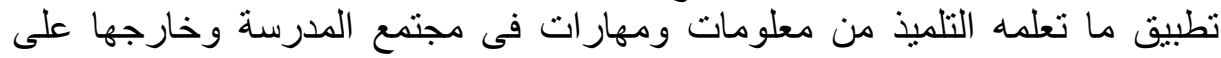

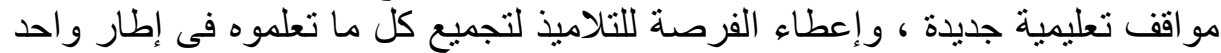

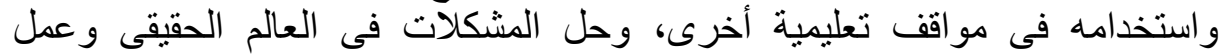


مجلة تربويات الرياضيات - المجلد (9 1 ) العدد (ץ) يناير 17 ـ ب م الجزء الثاني

بروفات تعليمية، وتعزيز التعلم بالتطبيق المباشر والتدريب العملى وتقديم التغذية الر اجعة، وتقديم الاختبار ات النهائية.

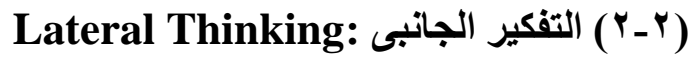

يرتبط التفكير الجانبى بالمفكر العالمى ( إدوارد دي بونو ) الذى بطلق عليه باللغة

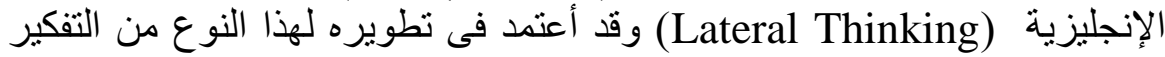

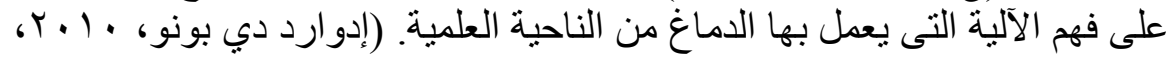

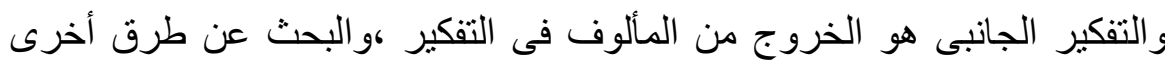

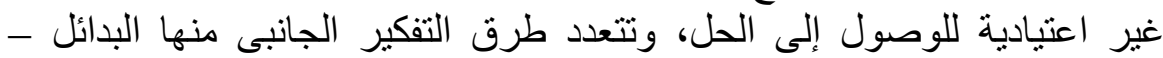

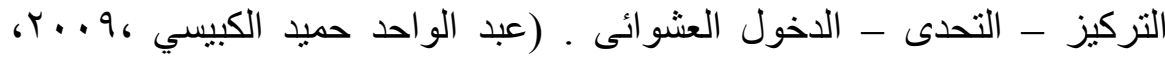

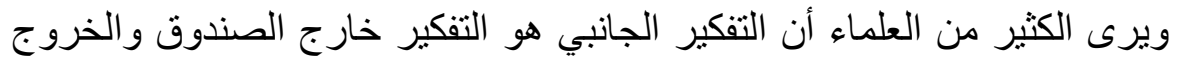
من نمطية التفكير الموضوعي إلى التفكير المنطقي الإبداعي. (طارق السويدير البران (YVA ، Y...人。

مبادئ التفكير الجانبي: Lateral Thinking Principles ا التعرف على الأفكار المتسلطة والتي تستقطب باقي الأفكار. r. البحث عن اختيار ات إدر اكية بديلة عن الرؤية الأحادية .

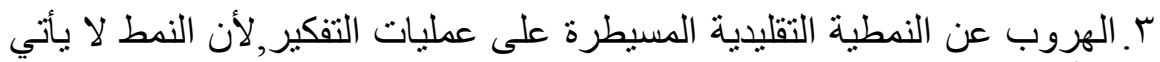
بأفكار جديدة. ع.استخدام الصدفة ,أي إدخال عنصر من العشوائية والمفاجأة لتجديد الأفكار.

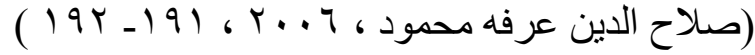
عناصر التفكير الجاتبى :

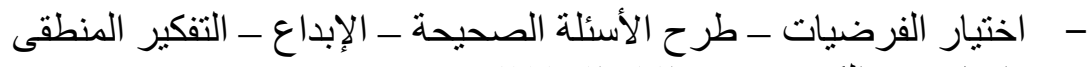

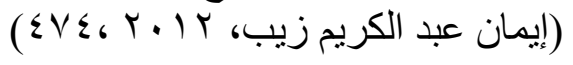
منظومة التفكير الجانبى: ا ـ مدخلات (أفراد لديهم الاستعداد للتفكير - أساليب تكنولوجية - مناخ بيئي إبتكارى) r ـ عمليات (إدر الك الحالة للتفكير - حضانة الفكرة - التحقق من الفكرة أو الحل) 
r- مخرجات (أفكار جديدة - طرق عمل جديدة - نماذج جديدة). (عبد الواحد حميد

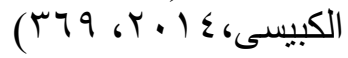

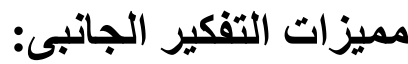

ا - يبتكر أكبر قدر ممكن من الحلول و البدائل .

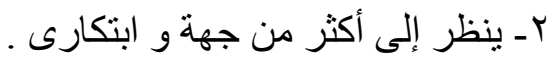

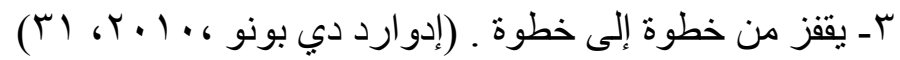

\section{مهارات التفكير الجاتبى : Lateral Thinking Skills}

: Generation of new Perception توليا ادراكات جديدة

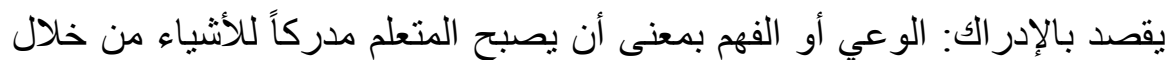

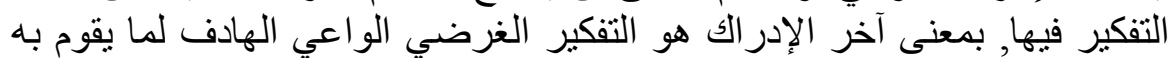

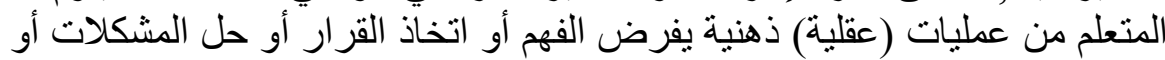

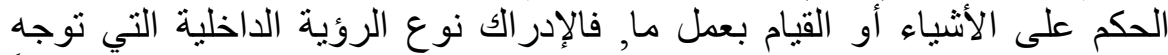

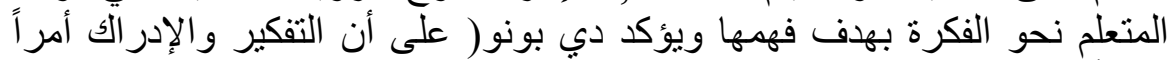

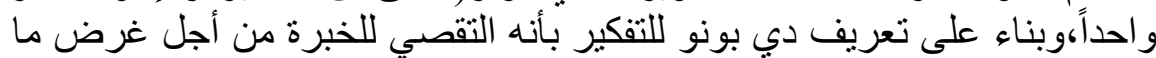

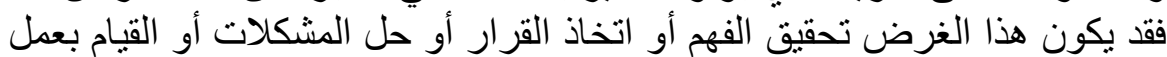

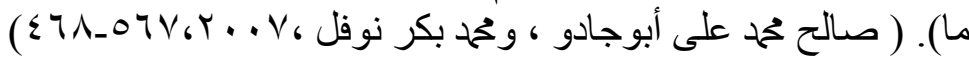

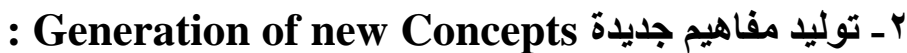

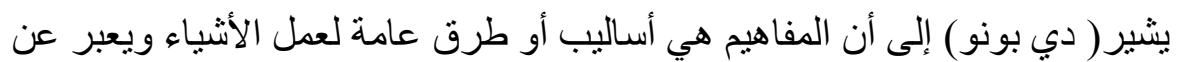

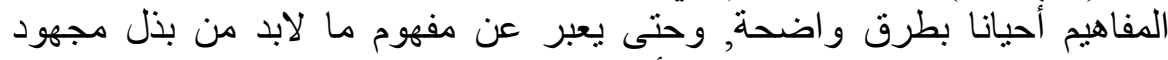
لاستخلاص هذا المفهوم. وثمة ثثلاثة أنو اعن من المفاهيم: أ ـ مفاهيم غرضية: أو ذات هدف وهي تتعلق بما يحاول المتعلم أن يحققه.

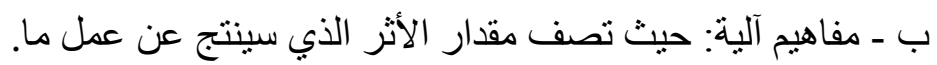
جـ - مفاهيم القيمة: والتي تشير إلى الكيفية التي يكتسب العمل من خلالها قيمته.

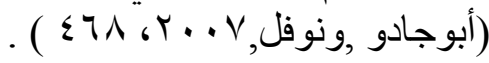

من المحتمل أن تكون القدرة على تكوين المفاهيم المجردة هي أساس القدرة على القى

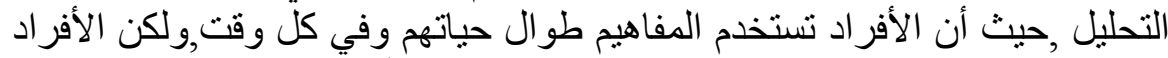

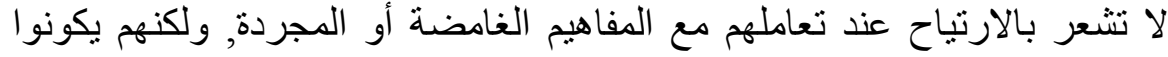


أكثر ارتياحاً عندما يتعاملون مع المفاهيم المحسوسة. (عبد الواحد حميد

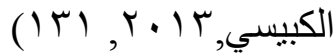

\section{بـ توليد أفكار جديدة Generation of new Ideas}

يعرف (دي بونو) الفكرة بأنها شيء يتصور( يفهم) من خلال العقل والأفكار هي

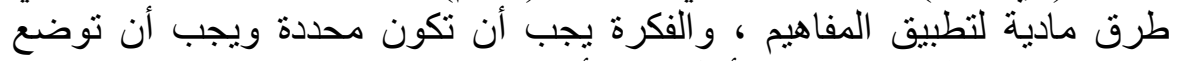

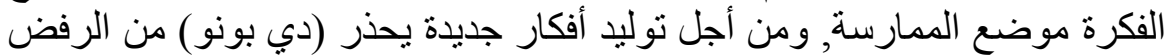

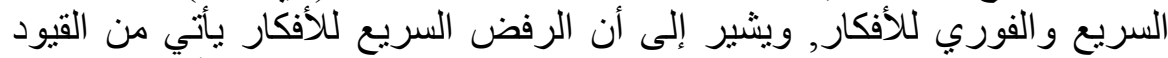

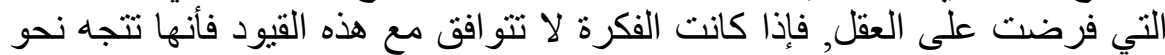

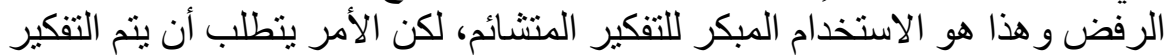

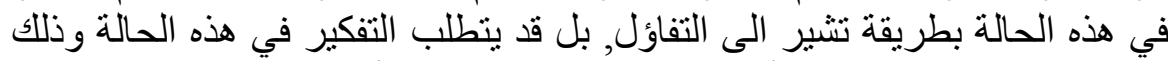

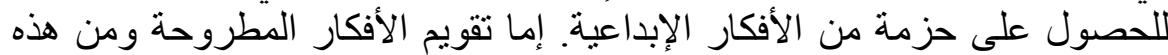

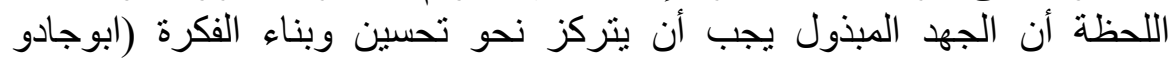

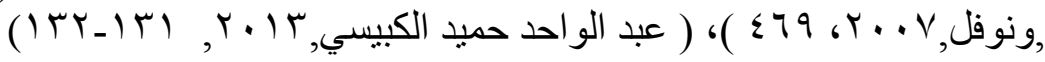

\section{ع - توليد بدائل جديدة Generation of new Alternative}

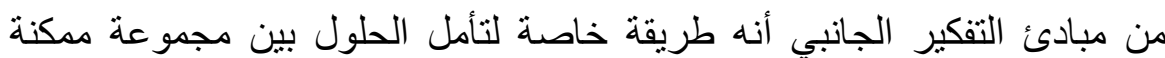

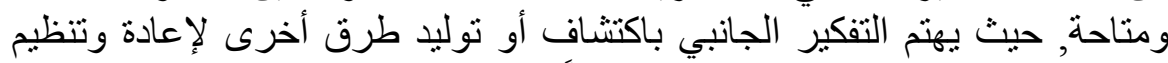

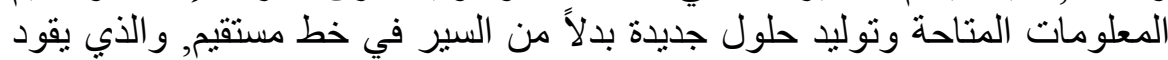

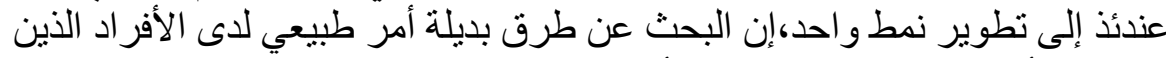

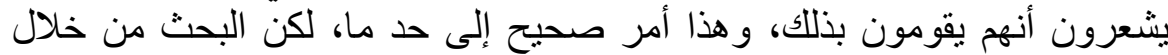

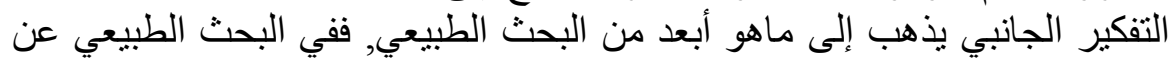

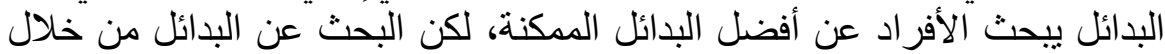

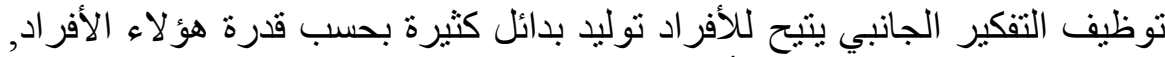

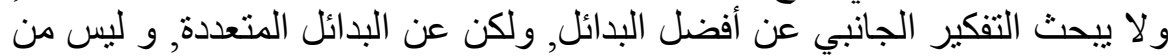

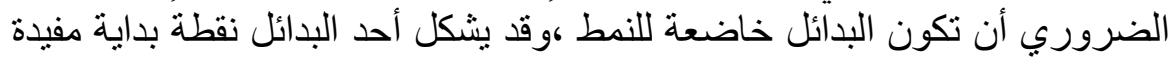

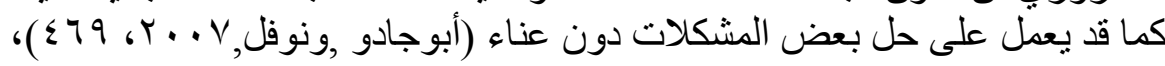

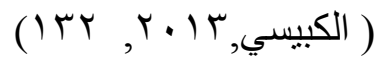

\section{هـ توليد إبداعات (تجديدات) جليدة Generation of new creativity}

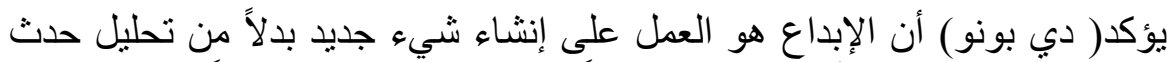

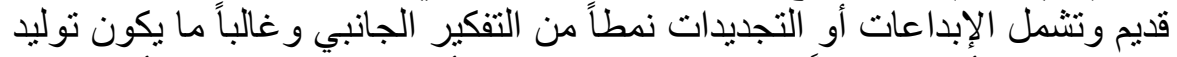

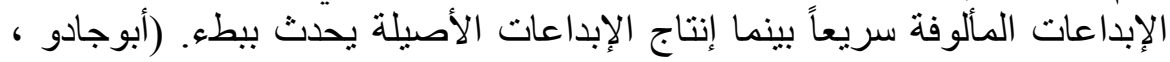

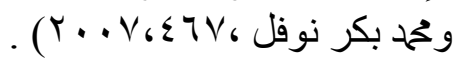


من خلال ماسبق نجد أن التفكير الجانبى يشجع على ممارسة التفكير خارج

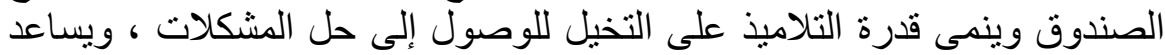

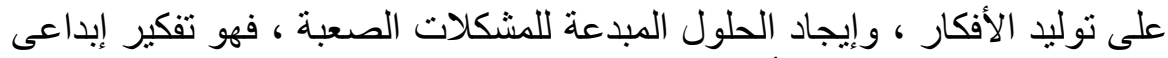

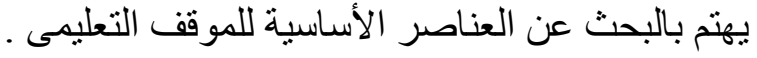
ومن الاراسات المرتبطة بالتفكير الجانبى:

- دراسة (Kumari \& Aggarwal,2012) أجريت فى الهند وهدفت لإيجاد

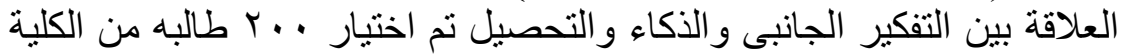

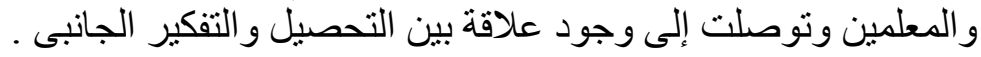

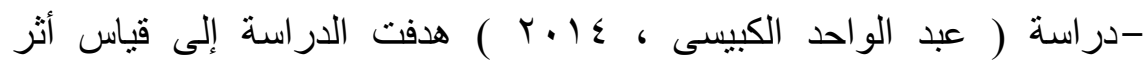

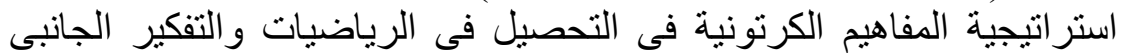

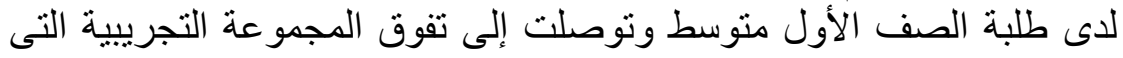
درست باستخدام استر اتيجية المفاهيم الكرنونية.

\section{Self-regulation : التظيم الذاتى (r-r)}

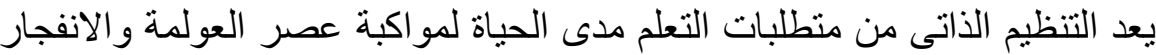

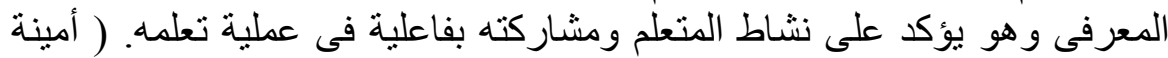
(Y...V، r

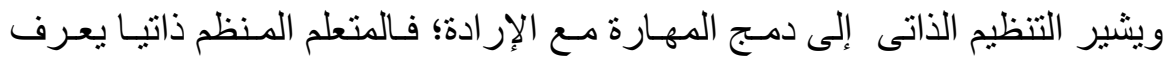

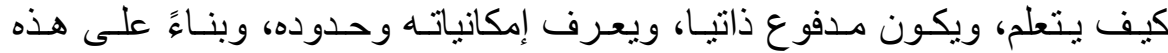

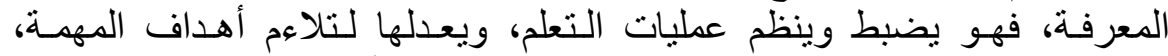

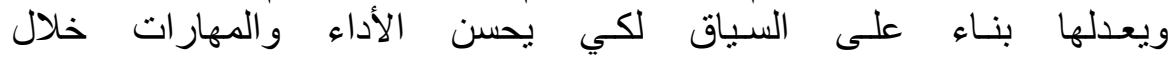
الممارسة. (Montalvo \& Gonzalez,2004,28)

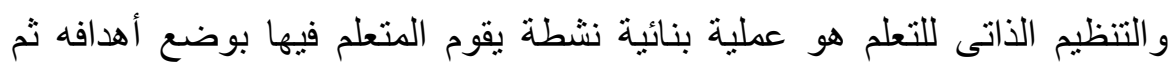

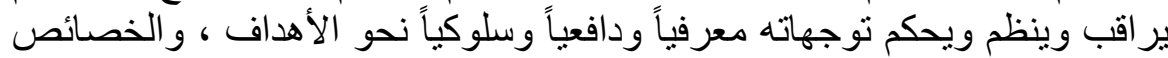

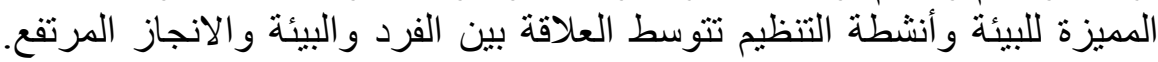

(Pintrich,2000,453)

أما موسوعة ( Wikipedia,2010) فتصف التنظيم الذاتى من المنظور المعرفى (مكي على أنه التفاعل الثثلاثى بين الفرد (معتقداته عن نجاحه ) وسلوكه (مشاركته فى التى 
المهمة) و البيئة (التغذية الراجعة من المعلم) وتشير إلى سمات ثناثة تميز التنظيم الذاتى هى : -ملاحظة الذات ومر اقبة أنشطة الفرد ـ ـ التفاعل الذاتى لمخرجات التعلم. - التقويم الذاتى للأداء. - - ماء. وتتضح أهية التظيم الذاتى للتعلم فى أنه من العوامل التى تشرح أداء المتعلمين،

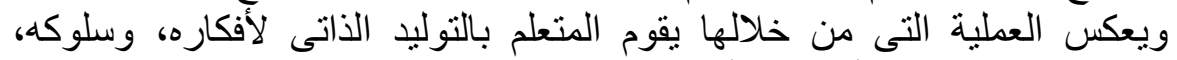

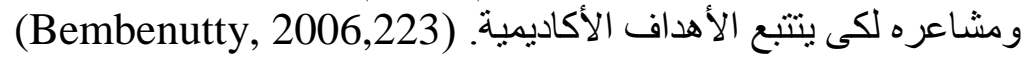

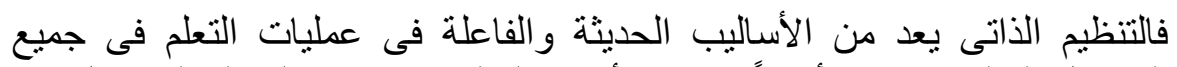

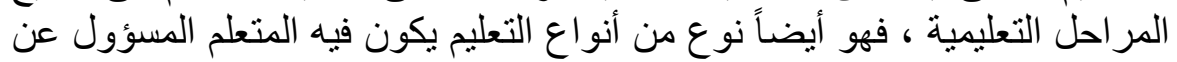
التخطيط للدرس وللمادة العلمية التى ير غب في في تعلمها وفى أنى التنفيذ و التقويم .

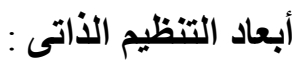

يقدم بوردي (Purdie) نموذجا يتضمن أربعة مكونات للتعلم المنظم ذاتياً، هي:

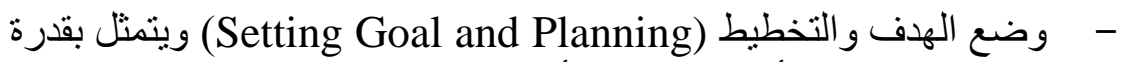

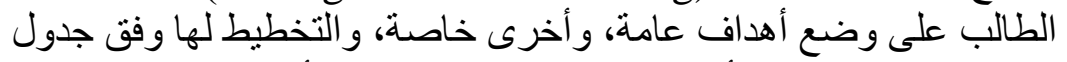

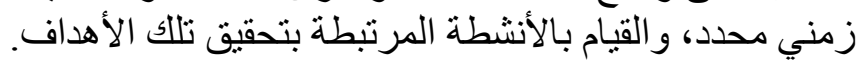

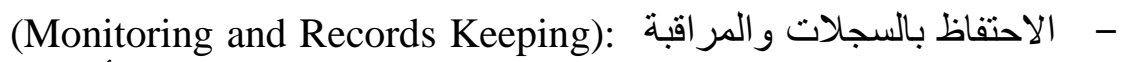

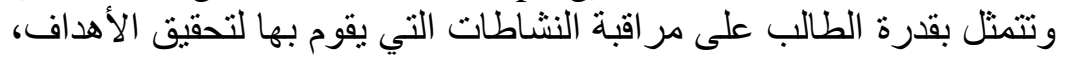

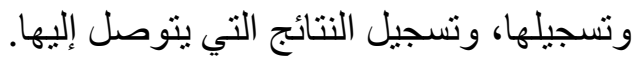

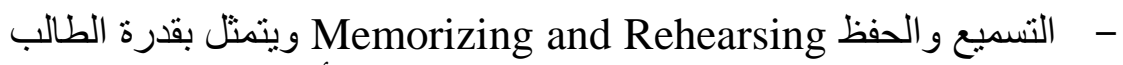
على حفظ المادة عن طريق تسميعها بصورة جهرية أو صامتة.

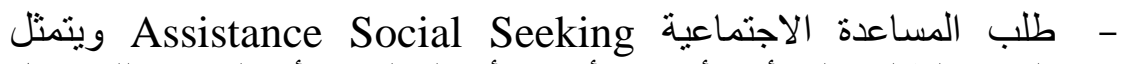

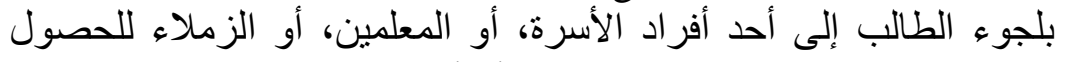

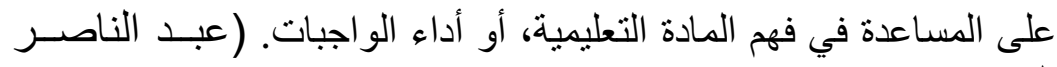

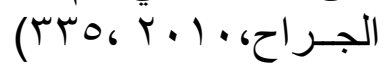

وقد حدد (Pintrich,2004,390) أبعاد التنظيم الذاتى المتمنلة فى الاستثارة والتنشيط

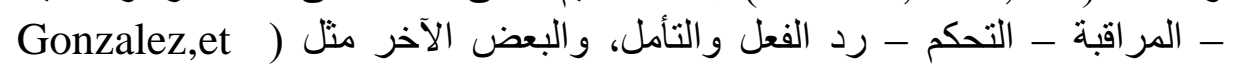

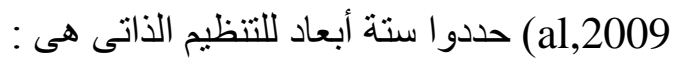




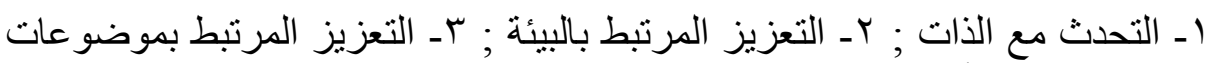

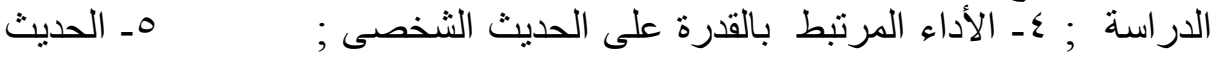

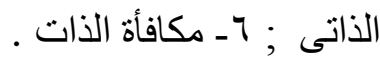

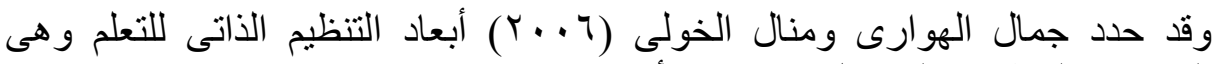
التسميع - التنظيم - التفصيل - تحديد الأهداف. وتم تحديد أبعاد التنظيم الذاتى فى البحث الحالى في ضو ء خمس أبعاد

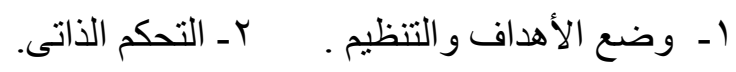
ع ـ الإحتفاظ بالسجلات و المر اقبة .

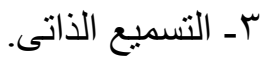

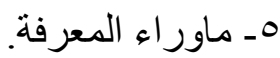

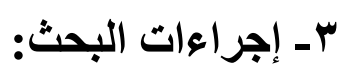
للإجابة على أسئلة البحث و التحقى من صحة فروضه ، أتبع الباحث ما يلى:

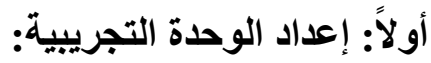
أـ اختيار الوحدة:

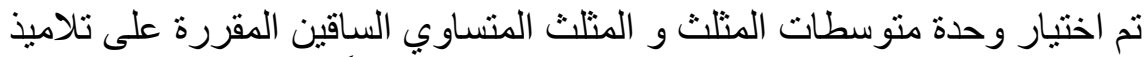
الصف الثانى الإعدادى بالفصل الدراسى الأول مجالاً للبحث وذلت الكث للأسباب التالية:

- - تتضمن الوحدة مفاهيم هندسية أساسية تمثل جانباً هاماً من البنية المعرفية

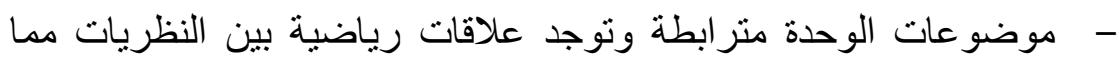

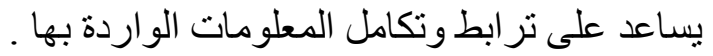

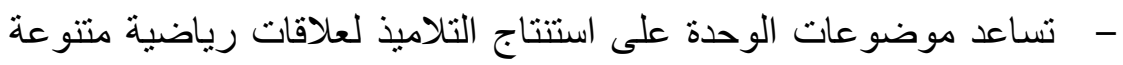
مما يثرى تفكير هم. - - احتواء الوحدة على عدد من الأنشطة والمهام التعليمية التى تثير تفكير لتهير

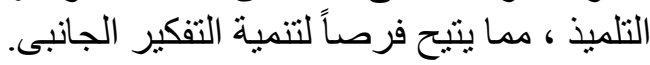

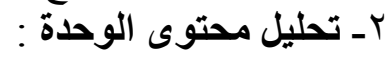

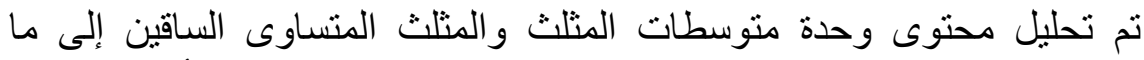

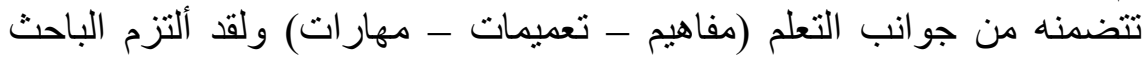
بالتعريفات التالية لكل من المفهوم - التعميم ـ المهارة . تعميمات 


\section{مجلة تربويات الرياضيات - المجلد (9 1) العدد (Y) يناير 17 ـ ب م الجزء الثاني}

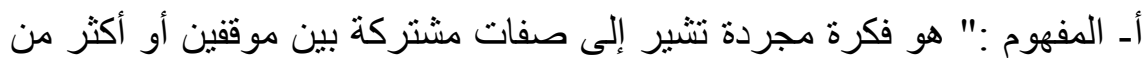

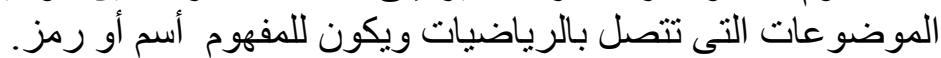

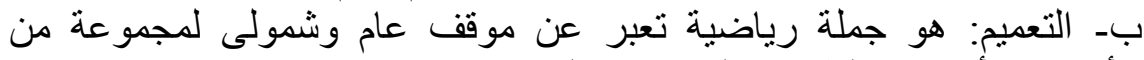

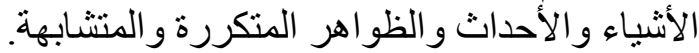

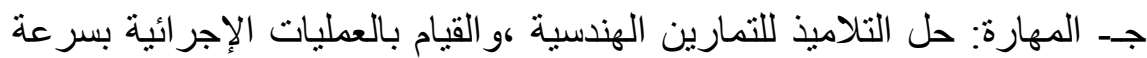

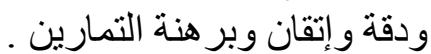

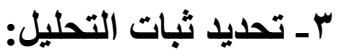

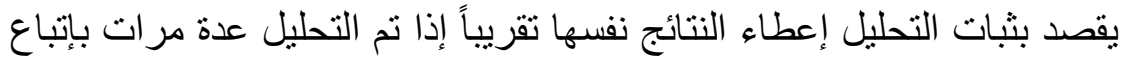

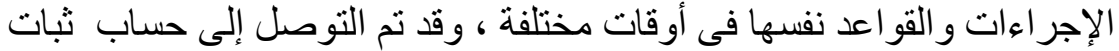
التحليل باتباع الخطو ات الاع التالية :

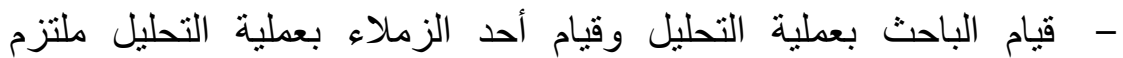

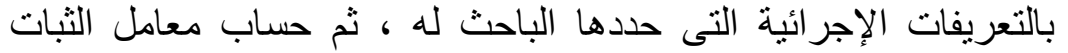

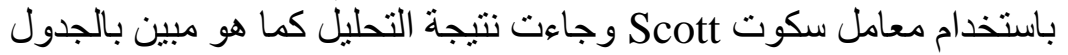
التالى :

(r) ( إدول

\begin{tabular}{|c|c|c|c|c|c|c|}
\hline \multirow[b]{2}{*}{ 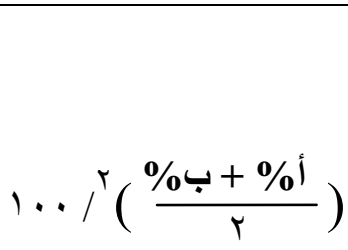 } & \multirow{2}{*}{ (أ\%- ب\%) } & \multicolumn{2}{|c|}{ للتكراراتة المئوية } & \multicolumn{2}{|c|}{ مجموع التكرارات } & \multirow[t]{2}{*}{ فئات } \\
\hline & & ب\% & \% & الزميل & (أل) & \\
\hline $10,7$. & 1 & $r q$ & $\varepsilon$ & IV & 19 & مفاهيم \\
\hline 11,07 & $r$ & ro & $r r$ & 10 & 17 & تعميمات \\
\hline$V, \cdot Y$ & 1 & rq & rV & Ir & 14 & مهارات \\
\hline$r \varepsilon, 1 \wedge$ & $\varepsilon$ & $1 \ldots$ & $1 \ldots$ & $\leqslant \varepsilon$ & $\varepsilon \wedge$ & المجموع \\
\hline
\end{tabular}

من الجدول السابق بالتعويض فى معادلة سكوت وجد أن معامل سكوت = ب 9 ، • مما

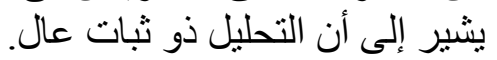

ـ ـ تحديد صدق التحليل:

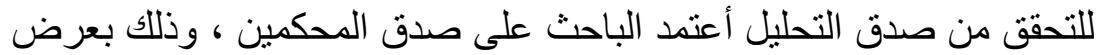

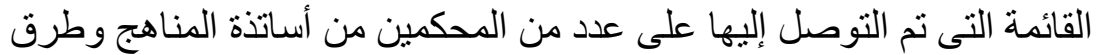

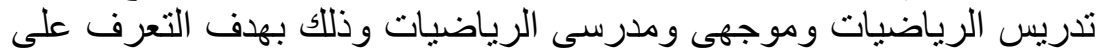

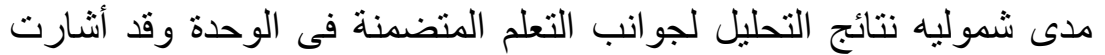

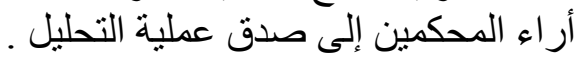




\section{وبذلك أصبحت استمارة التحليل صالحة للاستخدام كم هى فى ملحق (r ) ثانياً: إعداد دليل المعلم: وبلئ}

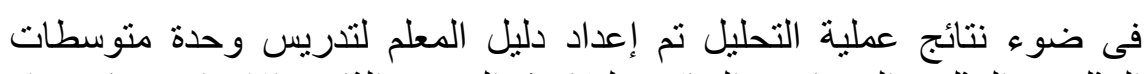

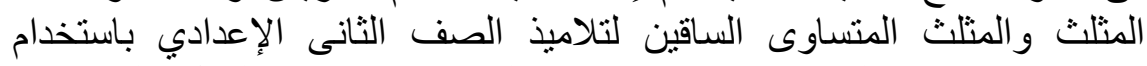

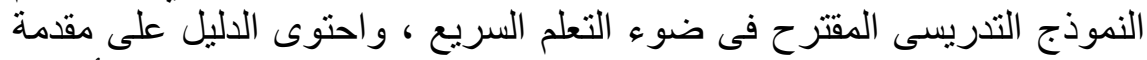

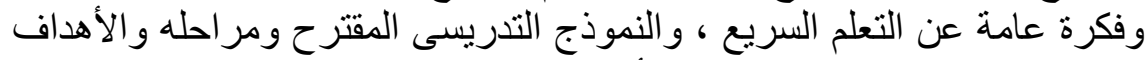

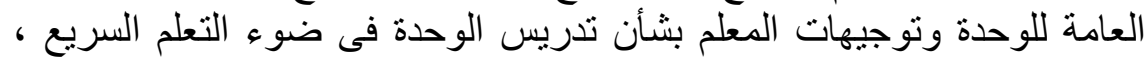

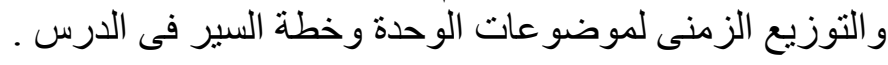

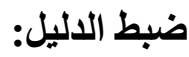
تم عرض الداليل على مجموعة محكمى الدراسة للتحقق من سلامة الأهداف

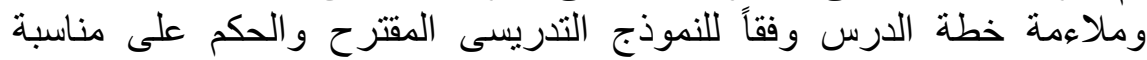

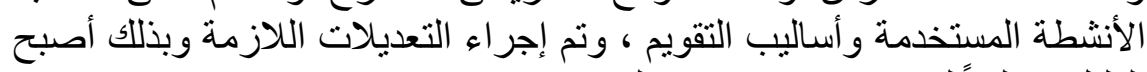

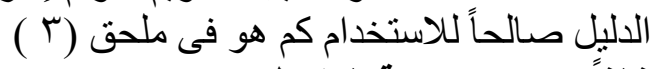

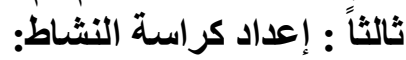

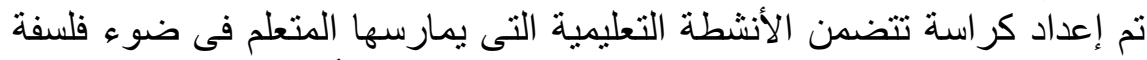

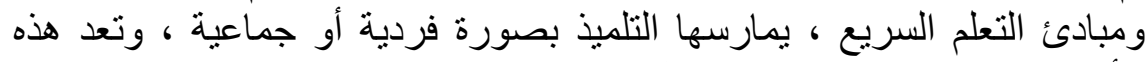

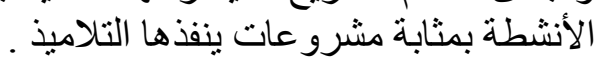
ضبط كراسة النشاط:

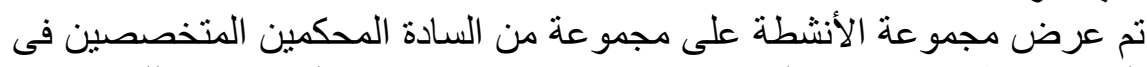

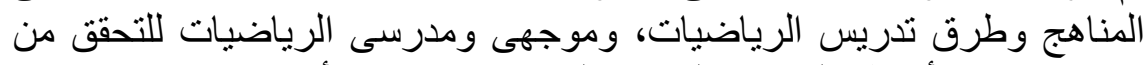

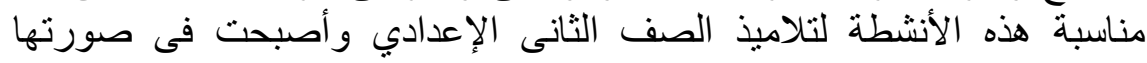

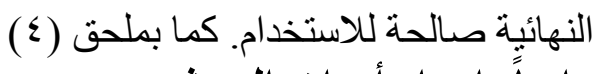

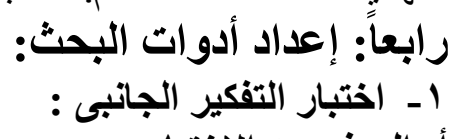

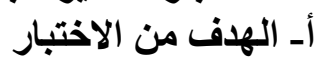
يهدف الاختبار إلى قياس قدرات الإن تلاميذ الصف الثانى الإعدادي على التفكير الجانبى فى الهندسة.

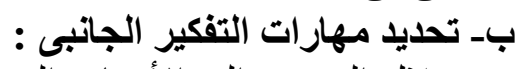

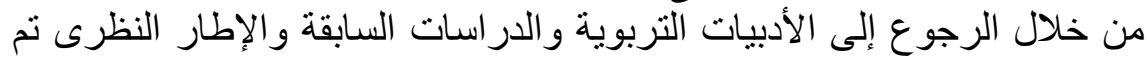

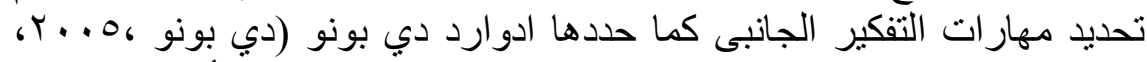

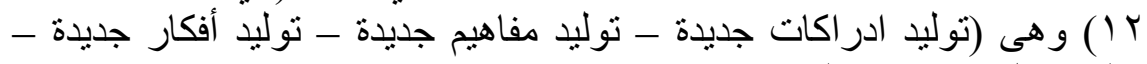

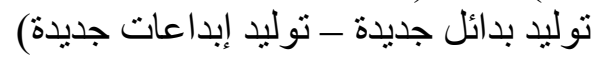


مجلة تربويات الرياضيات - المجلد (9 () العدد (ץ) يناير 17 ـ ب م الجزء الثاني

جـ تحديل مواصفات الاختبار:

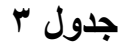

مواصفات اختبار التفكير الجانبى

\begin{tabular}{|c|c|c|c|c|c|c|}
\hline مجموع الأفكار & ابداعات & تولئل & جدأليار & مفاهيم & جلوليات & حته \\
\hline 0 & 1 & r & - & 1 & 1 & متوسطات المثلث \\
\hline 7 & - & 1 & $r$ & 1 & $r$ & المثلث المتساوى الساقين \\
\hline $\mathrm{v}$ & 1 & 1 & 1 & $r$ & 1 & السـاقينـات المثلــث المتســاوى \\
\hline $\mathrm{V}$ & 1 & $r$ & 1 & $r$ & 1 & المتسائج على الساقين نظريـات المثلــ \\
\hline 0 & 1 & - & 1 & $r$ & 1 & محور التماثل \\
\hline$r \cdot$ & $\varepsilon$ & 7 & 0 & 9 & 7 & المجموع \\
\hline
\end{tabular}

د- إعداد وصياغة مفردات الاختبار:

روعى عند صياغة مفردات الاختبار النقاط التالية :

- - سهولة ووضوح الألفاظ و المعطيات و المطلوب فى كل مفردة .

- أن تكون مرتبطة بالمفاهيم والمهار ات الموجودة بوحدة الهندسة .

- - أن تتضمن المفردات أفكار مرتبطة بمهار ات التفكير الجانبى.

- - أن تكون شاملة ومتنو عة .

هـ ـ صياغة تعليمات الاختبار:

تم صياغة نعليمات الاختبار بسهولة ووضوح وبدرجة ملائمة لمسنوى تلاميذ الصف الثانى الإعدادي.

و - طريقة تصحيح الاختبار:

بعد الانتهاء من إعداد الاختبار فى صورته النهائية تم إعداد مفتاح لتصاد لتصحيح الاختبار ، يتم تصحيح الاختبار فى ضوء اعثى الخطو ات الآتية: 
أ- أسئلة الإكمال و الاختيار من متعدد: درجة واحدة فقط لكل فراغ .

بـ الأسئلة المفتوحة : وضع درجة لكل خطوة من خطو ات الإجابة.

و - التجربة الاستطلاعية للاختبار

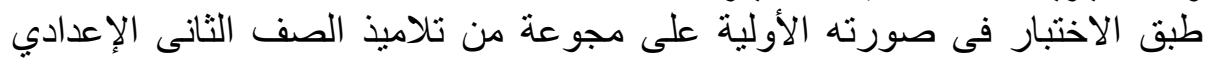

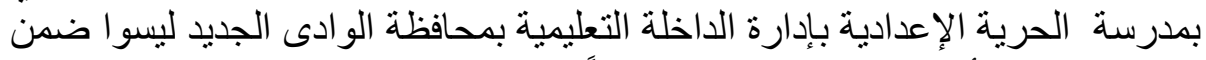

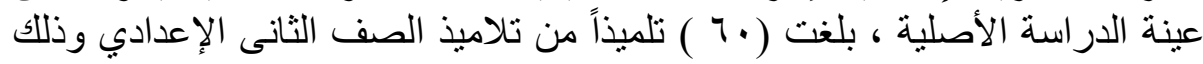

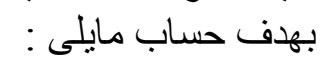

ا ـ تحديا زمن الاختبار :

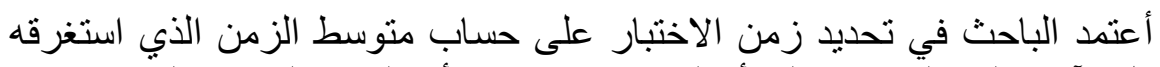

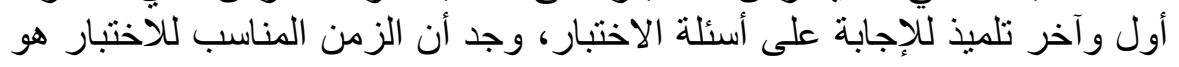
(1..)

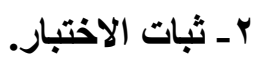

ا - استخدم الباحث فى إيجاد ثبات اختبار التفكير الجانبى طريقة ألفا كرونباخ

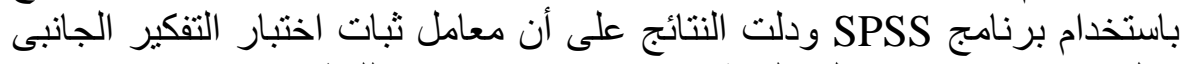
ككل ( ( ب.1. •) ، مما يدل على ثبات الاختبار وصلاحيته للتطبيق.

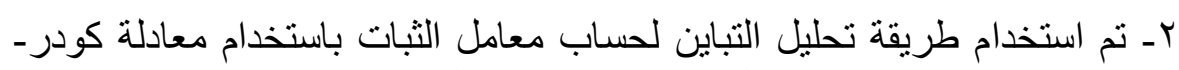

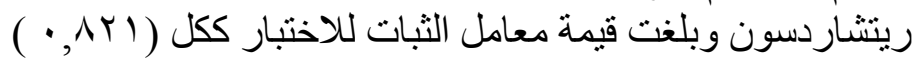

يتضح من ذلك أن اختبار التفكير الجانبى يتصف بثنبات مرتفع . r - صدق اختبار التفكير الجاتبى: أـ صدق المحتوى ( الصدق الظاهرى ) :

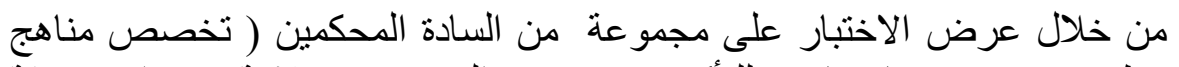

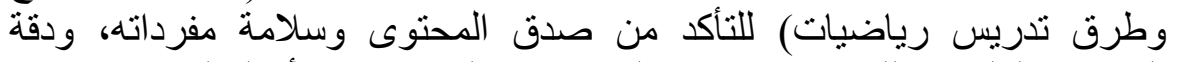

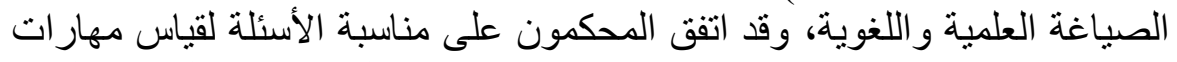
التفكير الجانبى، وعلى صلاحية الاختبار للتطبيق على تلاميذ الصف الصف الثانى الإعدادى.

بـ صدق المفردات: (الاتساق الداخلى) 


\section{مجلة تربويات الرياضيات - المجلد (9 1) العدد (Y) يناير 17 ـ ب م الجزء الثاني}

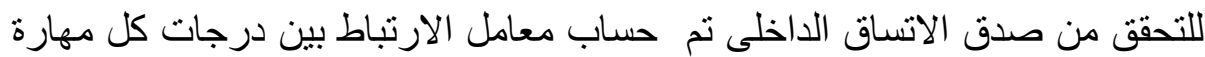

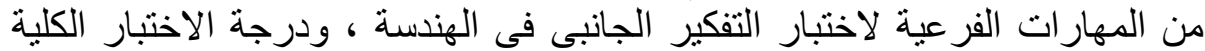

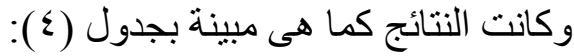

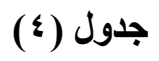

يوضح الاتساق الاخلى بين درجة كل مهارة فى الاختبار ودرجة الاختبار ككل

\begin{tabular}{|c|c|}
\hline معامل الارتباط & المهارات الفرعية \\
\hline$* *, \wedge 11$ & توليب ادراكات جديدة \\
\hline **:, $\vee 70$ & توليد مفاهيم جديدة \\
\hline$* *, \wedge Y V$ & توليد أفكار جديدة \\
\hline$* *, \wedge \leq \mu$ & توليد بدائل جديدة \\
\hline$* *, \vee 9$. & توليد إبداعات جديدة \\
\hline
\end{tabular}

العلامة (**) تدل على أن المهارة دالة عند مستوى ( 1 (..) جـ صدق المقارنة الطرفية:

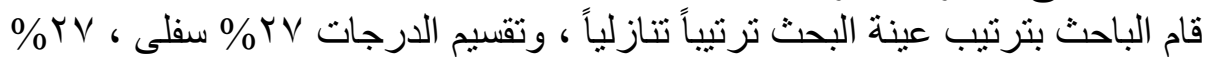

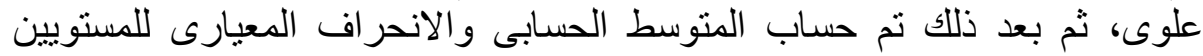

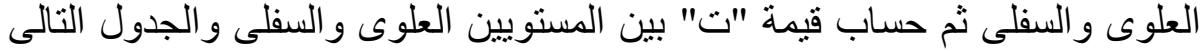

(•) جدول (ن) يوضح ذلك:

المتوسط الحسابى والاتحراف المعيارى وقيمة (ت) لالالة الفروق بين متوسطى درجات

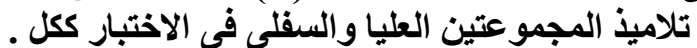

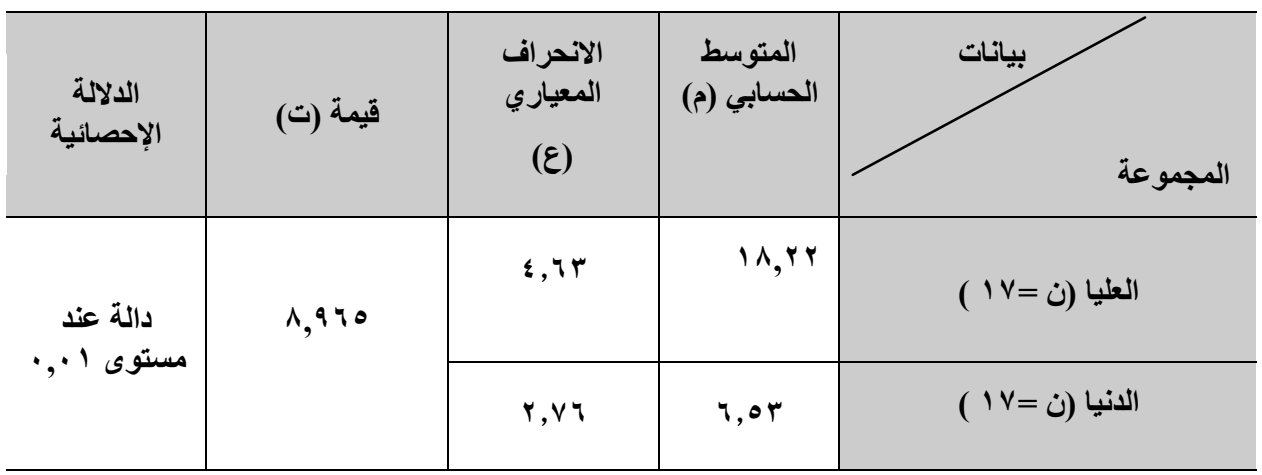




\section{مجلة تربويات الرياضيات - المجلد (9 1) العدد (Y) يناير 17 ـ ب م الجزء الثاني}

يتضح من الجدول السابث أن الاختبار قادر على التمييز بين الأقوياء والضعاف مما يدل على صدق الاختبار.

\section{ع ـ الصورة النهائية للاختبار:}

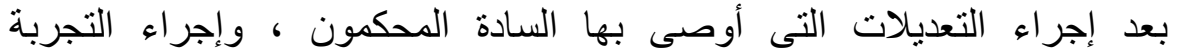

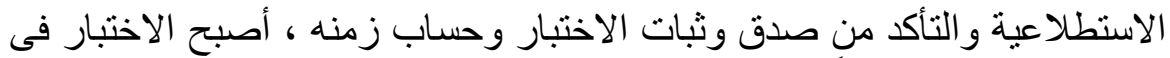

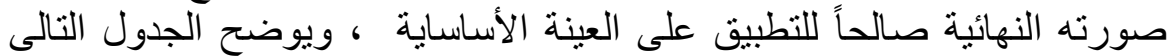

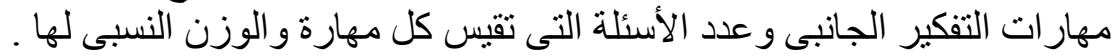

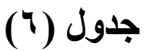

مواصفات الصورة النهائية لاختبار التفكير الجانبى

\begin{tabular}{|c|c|c|c|c|c|}
\hline \multicolumn{5}{|c|}{ أرقام مفردات الاختبار موزعة على المستويات } & \multirow[t]{2}{*}{ أبعاد الاختبار } \\
\hline توليد إبداعات & توليد بدائل جديدة & توليد أفكار & توليد مفاهيم & توليد ادراكات & \\
\hline 10 & 11.10 & - & 0 & $T$ & متوسطات المثلث/ \\
\hline - & IY & $9 . V$ & $\varepsilon$ & $r \cdot r$ & 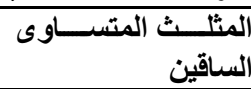 \\
\hline $1 \varepsilon$ & 11 & $\mathrm{~V}$ & I، & 1 & 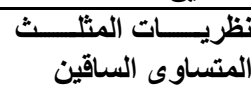 \\
\hline $1 \varepsilon$ & $1 Y, 11$ & $\Lambda$ & 9.0 & 1 & 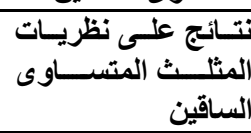 \\
\hline 14 & - & $\Lambda$ & \& & $r$ & محور التماثل \\
\hline$\varepsilon$ & 9 & 0 & 9 & 9 & المجموع \\
\hline
\end{tabular}

ـ تصميم و إعداد مقياس التنظيم الأتى للتعلم:

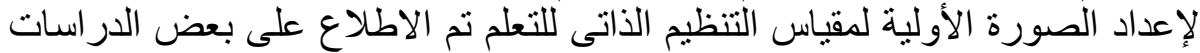

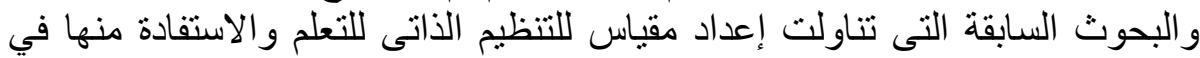

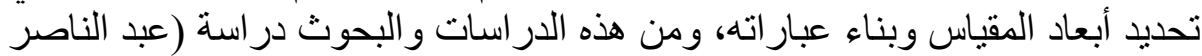

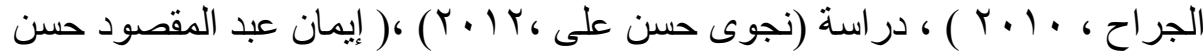

وقد تم بناء مقياس التنظيم الذاتى وفقاً للخطو ات التالية: 
ا - تحديا الهذف من المقياس:

قياس مهار ات التنظيم الذاتى لاتى تلاميذ الصف التف الثانى الإعدادى مجموعة البحث

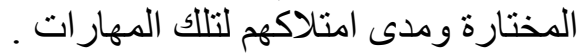

ب - تحديد أبعاد المقياس:

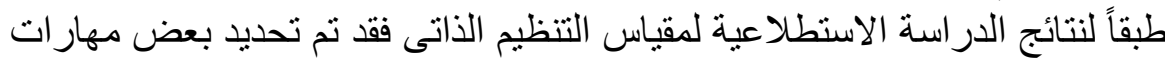

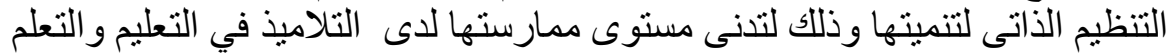

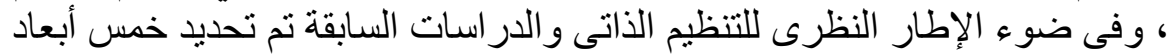

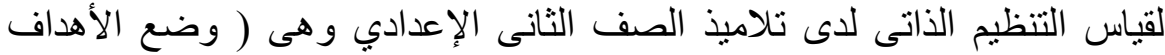

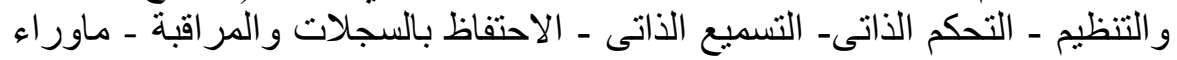

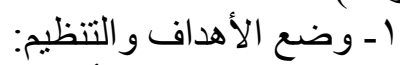

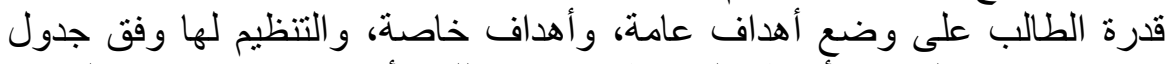

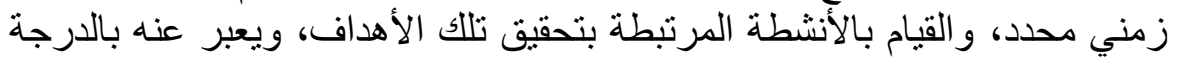
التي يحصل عليها الطالب في مقياس التنظيم الذاتى.

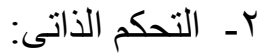

عملية الحكم على السـلوك أو العمل، ويقصد به مقارنة مستوى أداء الفرد الحف الحالي بما

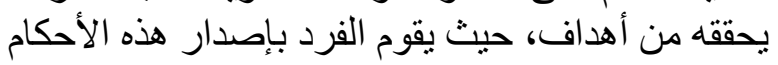
بـ - التسميع الذاتى: أهنى

يتمثل بقدرة الطالب على حفظ المادة عن طريق تسميعها بصورة جهرية أو صامتة،

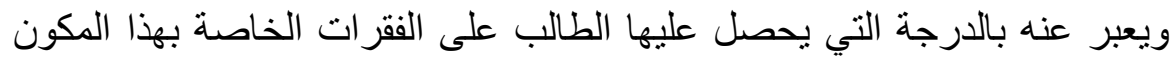
في مقياس التنظيم الذاتى. عـ - الاحتفاظ بالسجلات والت والمر اقبة

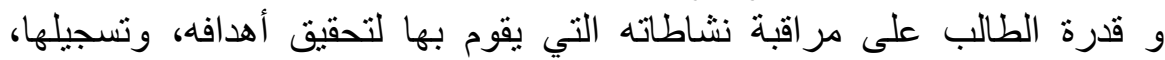

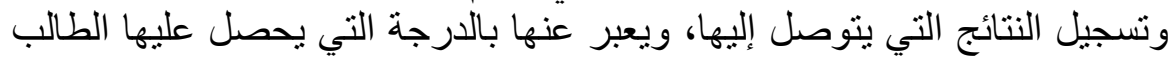

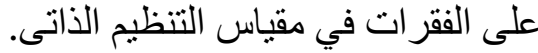
0ـ ماور اء المعرفة :

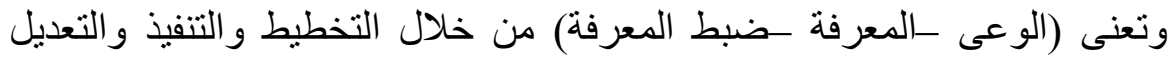

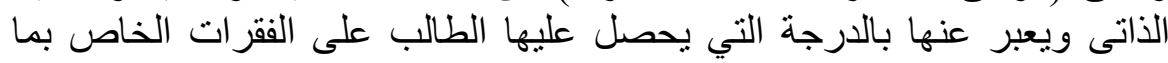

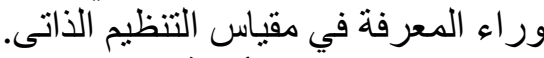
r- إعداد الصورة الأولية للمقياس:

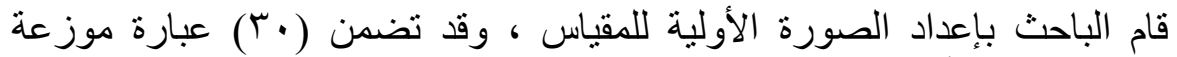

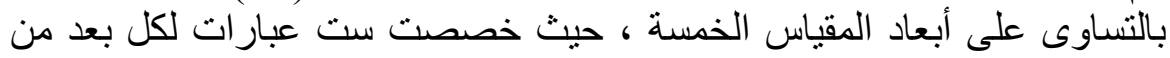
الأبعاد الخمسة. 
مجلة تريويات الرياضيات - المجلد (9 1) العدد (ץ) يناير 19 ـ ب م الجزء الثاني

(v) جدول

أبعاد مقياس التنظيم الأتى وأرقام العبارات في صورته الأولية

\begin{tabular}{|c|c|c|}
\hline الإجمالى & رقم العبارات & البعد \\
\hline 7 & ) ו Y, Y, צ، O، & وضع الهُف و التنظيم \\
\hline 7 & 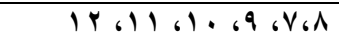 & التحكم الأتيى \\
\hline 7 & $11,1 V_{6} 10_{6} 17,1 T_{6} 1 \varepsilon$ & التسميع الذاتى \\
\hline 7 & $Y \leqslant, Y Y, Y Y, Y 1, Y \cdot 69$ & الإحتفاظ بالسجلات و المراقبة \\
\hline 7 & 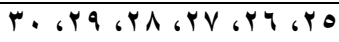 & ماوراء المعرفة \\
\hline
\end{tabular}

- تم تطبيق المقياس على عينة من تلاميذ المرحلة الإعدادية مكونة من († (؟)

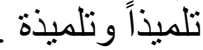

- وقد تم إتباع الخطوات المات التالية في إعداد الصورة الأولية للمقياس :

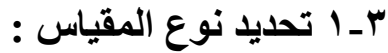

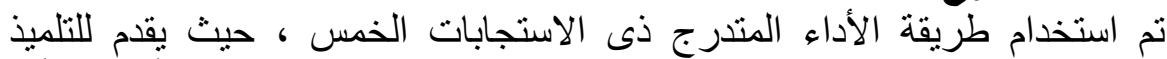

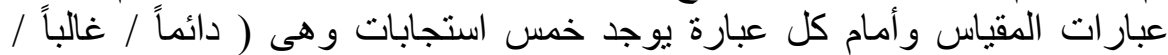

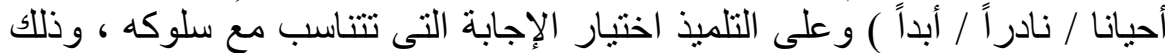

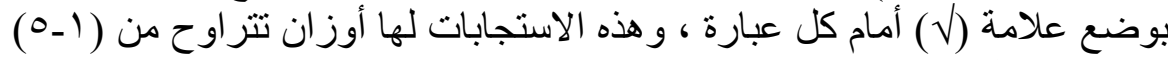

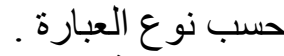

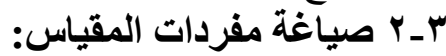

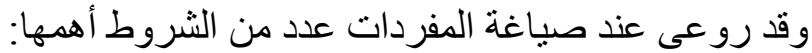
ل

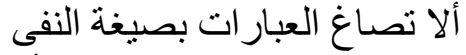
البعد عن العبار ات التى تحمل أكثر من فكرة .

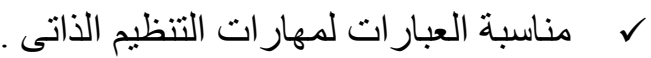
r-r وضع تعليمات المقياس:

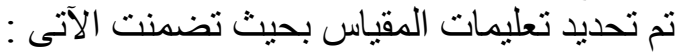

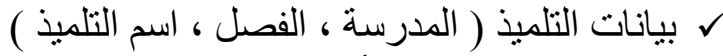

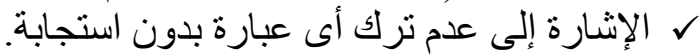

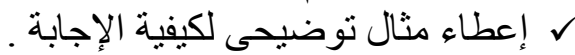

r- ـ تقدير الارجات وطريقة التصحيح:

ويمكن تحديد مفتاح توزيع درجات الماته المقياس بحيث ينقسم إلى نو عين:

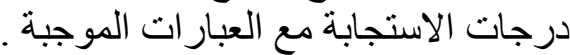
درجات الاستجابة مع العبار ات السالبة ـ كما يوضحها الجدولة العاب التالى : 
مجلة تريويات الرياضيات - المجلد (9 1) العدد (ץ) يناير 19 ـ ب م الجزء الثاني

جدول (^) ميزان تقدير الارجات على مقياس التظيم الذاتى

\begin{tabular}{|c|c|c|c|c|c|}
\hline \multicolumn{5}{|c|}{ مقياس تنظيم الأات } & اتجاه العبارات \\
\hline 1 & $r$ & $r$ & $\varepsilon$ & 0 & العبارات الموجبه \\
\hline 0 & $\varepsilon$ & $r$ & $r$ & 1 & العبارات السالبة \\
\hline
\end{tabular}

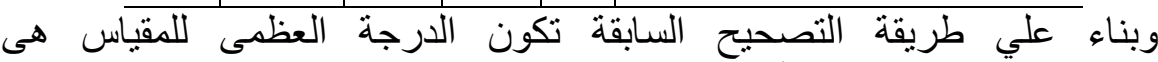
.

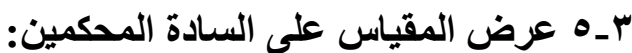

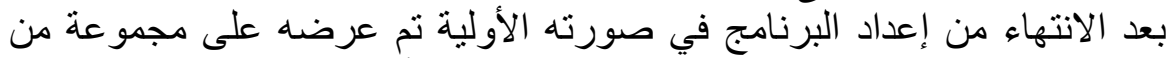

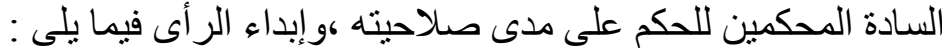

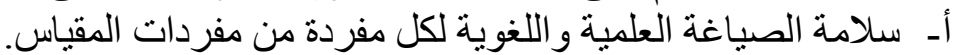

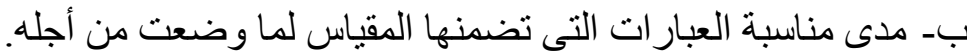

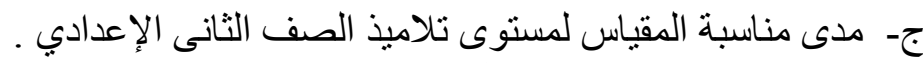
د- صحة التعليمات الموجهة للتلميذ.

وبناءً على آر اء السادة المحكمين لم يتم حذف الع أى بعد من أبعاد المقياس ، و وإنما

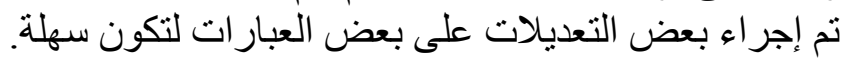

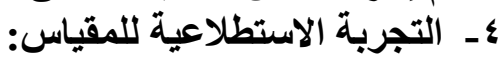

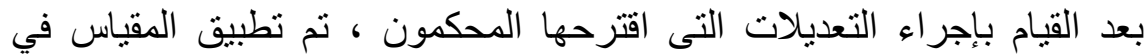

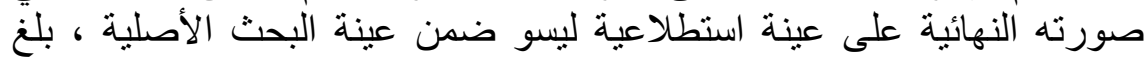

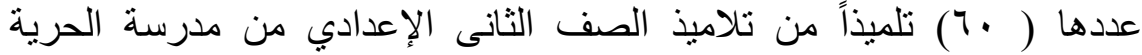

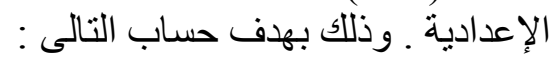

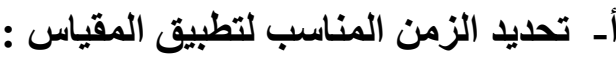

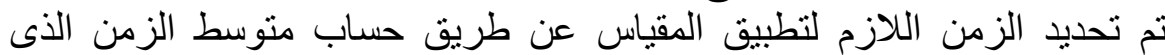

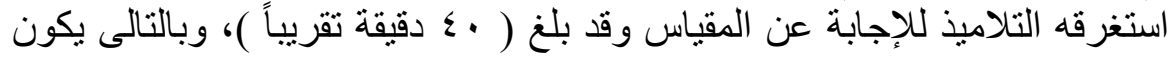
الزمن المناسب لتطبيق المقياس.

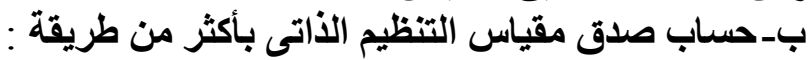

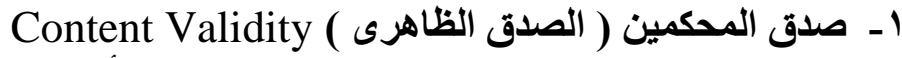

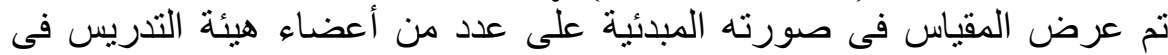

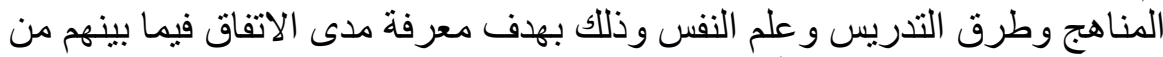

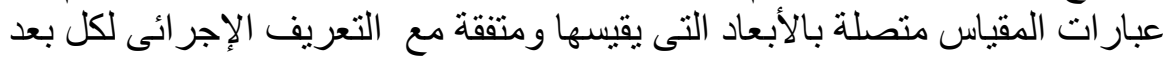

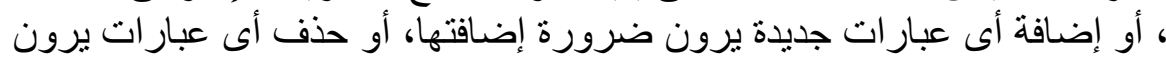

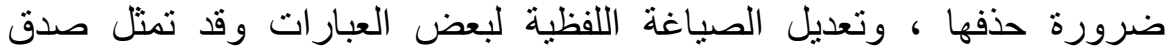
المحتوى في اتفاقهم على صلاحية المقياس للتطبيق. 


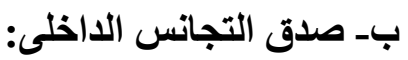

تم حساب صدق المفردات في مقياس التنظيم الذاتى عن طريق إيجاد قيمة معامل

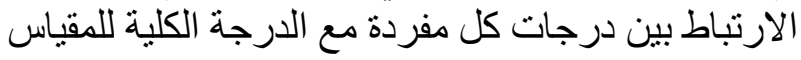

جدول (9)

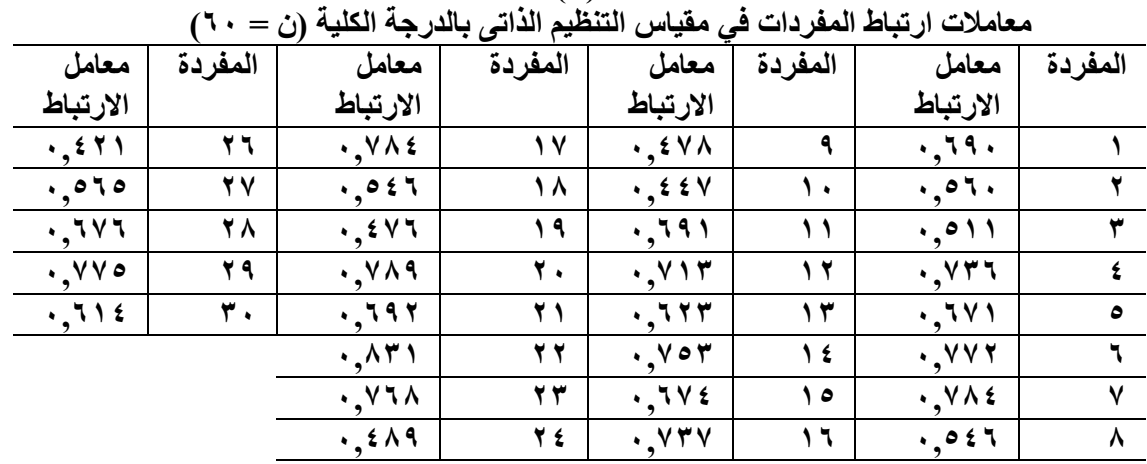

يتضح من الجدول (9) أن جميع معاملات الارتباط دالة عند مستوى ا +, · بؤكد ذلك على صدق المقياس.

\section{جدول (· (1)}

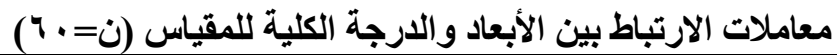

\begin{tabular}{|c|c|c|c|c|c|}
\hline المعرفة & والإحتفاظة بالسجلات & التسميع الذاتى & الألتى & والتنيع الأهداف & البعد \\
\hline, 0. & $\cdot, T \leqslant r$ & $\varepsilon$ & ס דז, & $\because \vee \wedge \wedge$ & رتباط \\
\hline
\end{tabular}

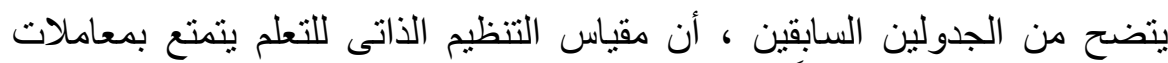

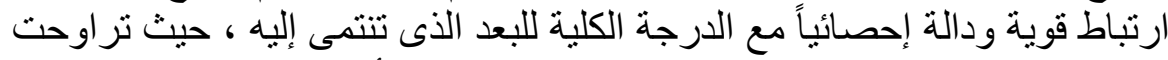

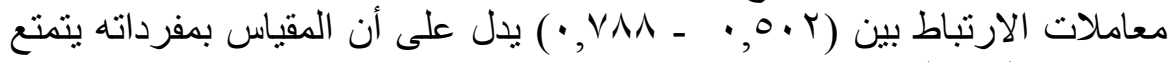

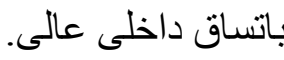

ج- الصدق العاملى: - (الم

قام الباحث بالتأكد من صدق المقياس باستخدام التحليل العاملى Factor Analysis

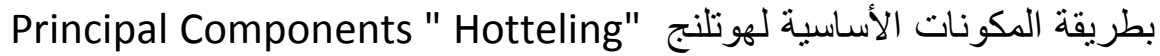

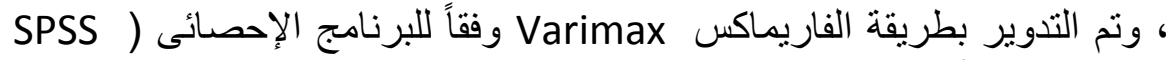

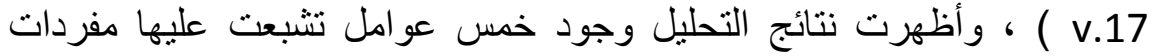

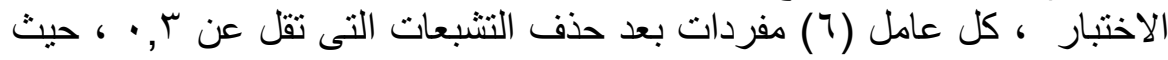




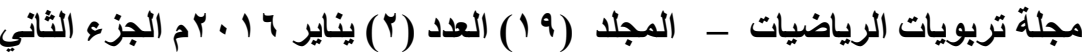

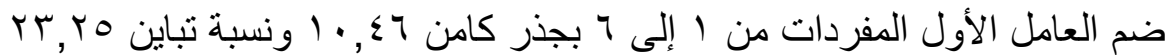

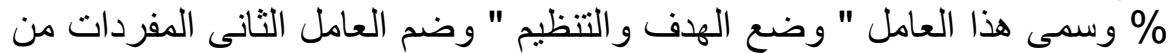

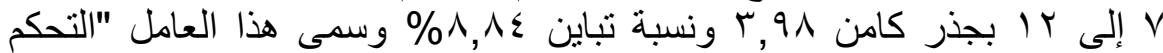

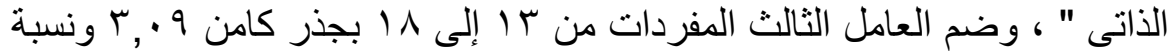

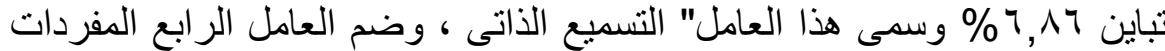

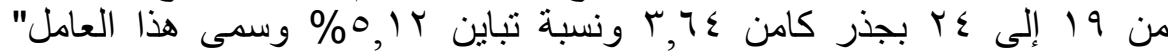

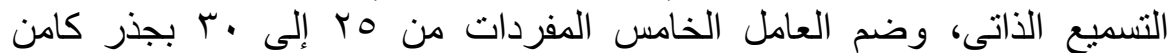

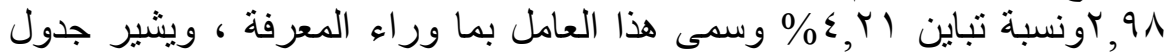

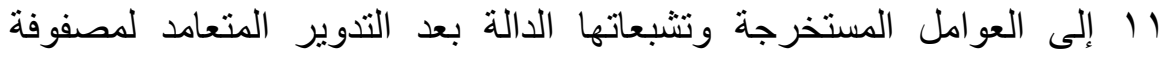
مفردات مقياس التنظيم الذاتى.

جلول (11) (لعامل

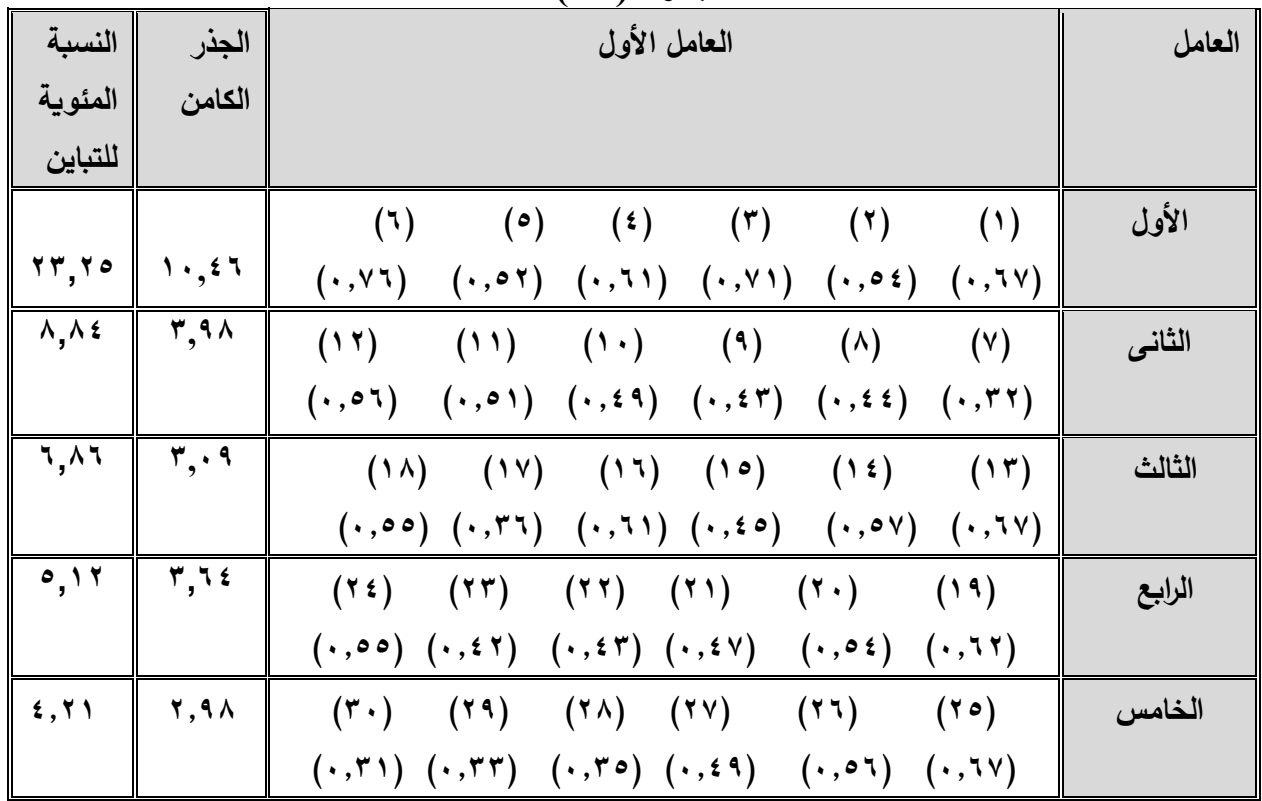

يتضح مما سبق أن منو سطات العو امل مقبولة, وأن جميع العوامل المكونة للقدر ات تتمتع

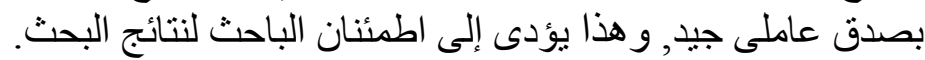

\section{هـ حساب معامل ثبات المقياس:}

تم حساب ثبات المقياس بعد تطبيقه على عينة استطلاعية عددها ( . 7) تلميذاً وتلميذة من تلاميذ الصف الثانى الإعدادي. بعدي. 


\section{مجلة تربويات الرياضيات - المجلد (9 1) العدد (Y) يناير 17 ـ ب م الجزء الثاني}

حساب معامل الثبات ألفا كرونباخ وطريقة التجزئة النصفية باستخدام معادلتي سبير مان بر اون وجنمان.

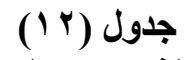

قيم معامل ألف كرونباخ وسبيرمان وجتمان للقياس ككل

\begin{tabular}{|c|c|c|c|}
\hline \multicolumn{3}{|c|}{ طرق الثبات } & المكونات \\
\hline جتمان & سبيرمان & ألفا & الارجة الكلية \\
\hline$\% \cdot, \vee \leqslant r$ & $\% \cdot, \wedge 11$ & $\% \cdot, \wedge \vee \varepsilon$ & \\
\hline
\end{tabular}

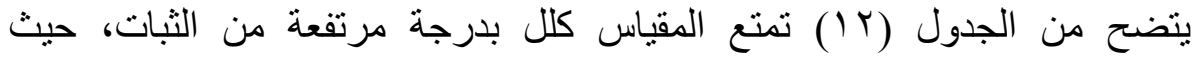

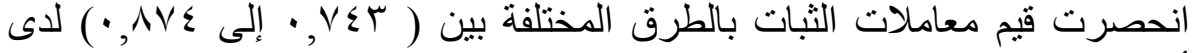

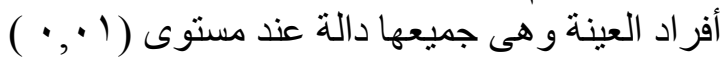

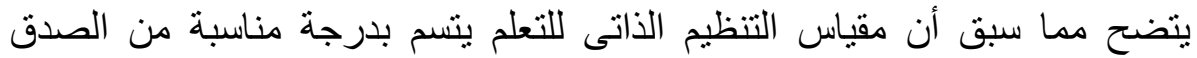

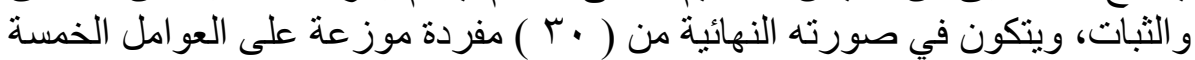
للتنظيم الذاتى .

\section{1 - الصورة النهائية للمقياس:}

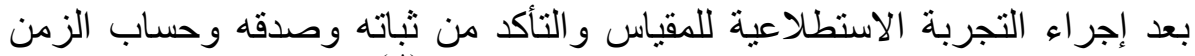

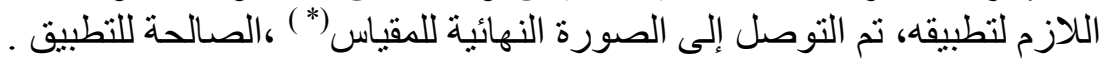
ويبين جدول (T I ) التالى مو اصفات المقياس في صورته النهائية .

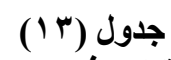

مو اصفات المقياس في صورته النهائية .

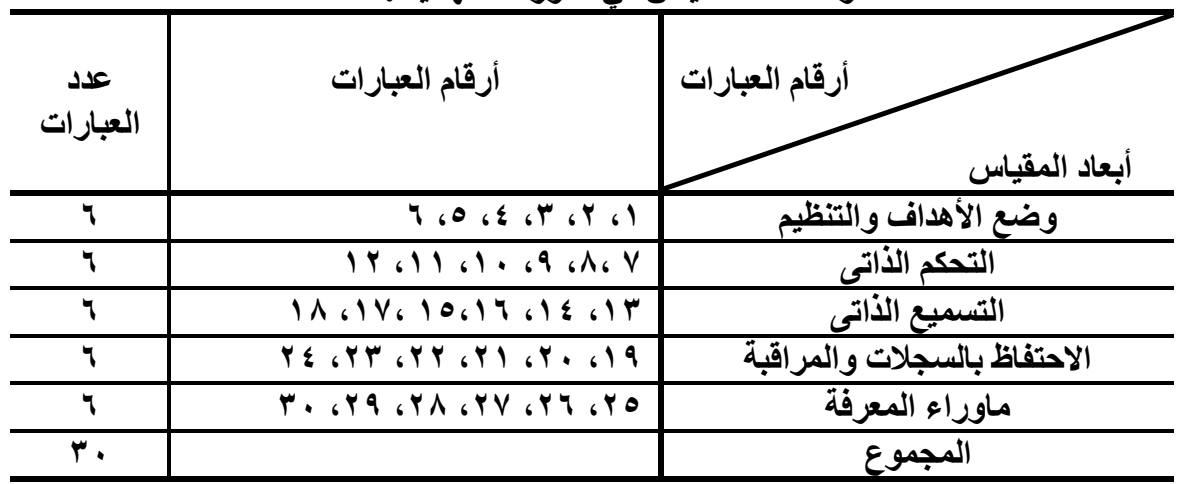

" ملحق (" ) مقياس التنظيم الذاتى لتلاميذ الصف الثانى الإعدادى * 


\section{خامساً: التصميم التجريبيى المستخدم:}

للتأكد من صحة الفروض استخدم المنهج شبه التجريبى ذو المجمو عتين التجريبية

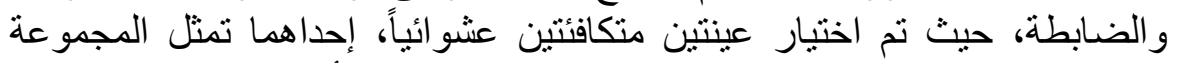

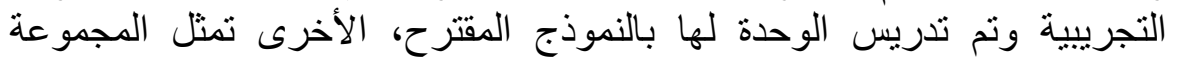

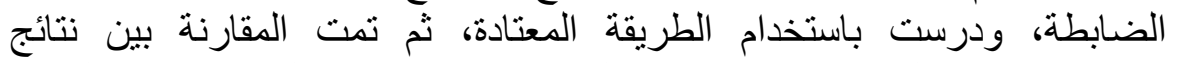

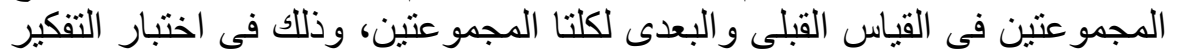

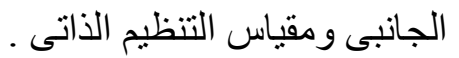

\section{سادساً: اختيار مجموعتي البحث وتحديد المتغيرات وضبطها: أـ اختيار مجموعتي البحث:}

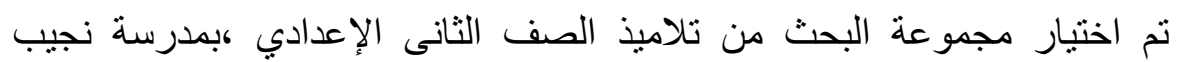

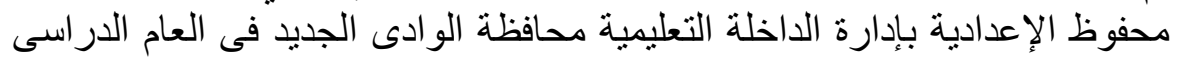

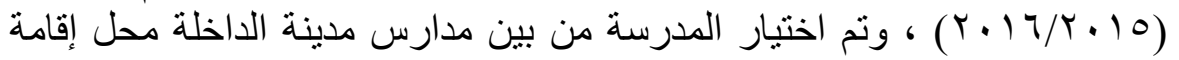
الباحث ويبين الجدول التالي ذلك:

جلول (

\begin{tabular}{|c|c|c|}
\hline المجموع & اسم المدرسة & المجموعة \\
\hline rq & مدرسة نجيب محفوظ الإعدادية & التجريبية \\
\hline$r q$ & مدرسة نجيب محفوظ الإعدادية & الضابطة \\
\hline VA & & المجموع \\
\hline
\end{tabular}

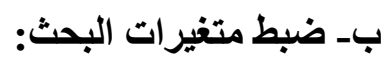

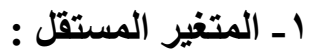

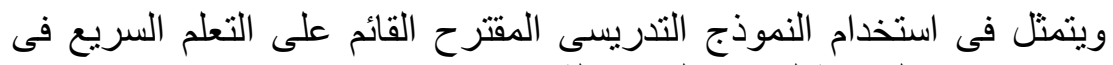
تدريس وحدة الهندسة لتلاميذ الصف التفوذ الثانى الإعدادي.

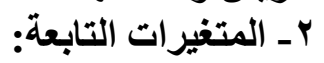

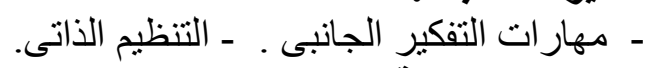

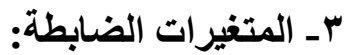

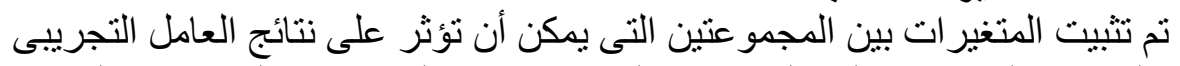

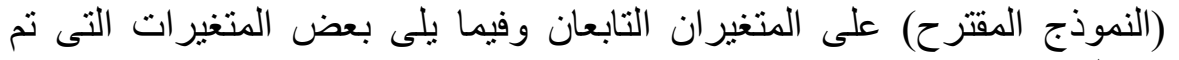




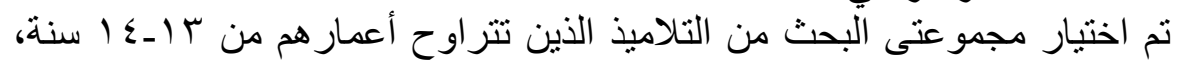

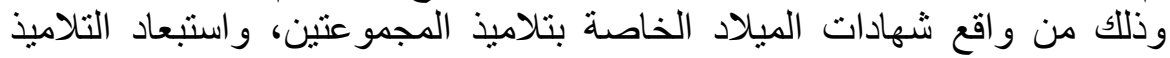
الباقين للإعادة.

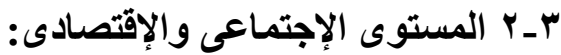

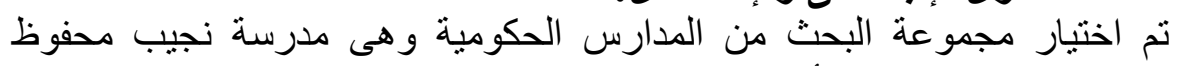

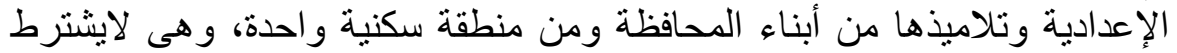

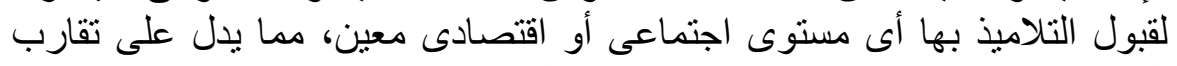

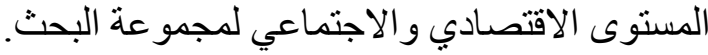

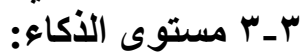
تم اختيار تلاميذ مجوعتي البحث بطريقة عشو ائية حيث أن تلاميذ الصف الصف الثانى

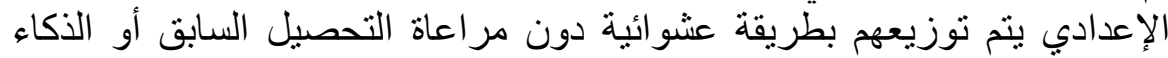

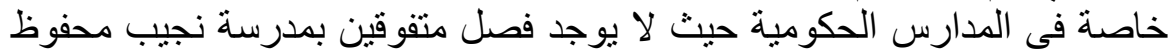
الإعدادية وبذلك تكون جميع الفصول منقاربة في نسبة الذكاء. r-s الجنس: لا يدخل عامل الجنس و أثره ضمن حدود البحث، فقد كانت مجموعتي البحث من

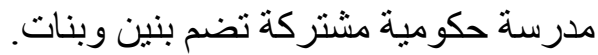

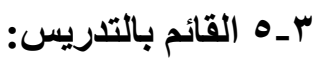
تم اختيار اثنين من المعلمين للقيام بالتدريس للمجمو عتين التجريبية والضابطة وقد

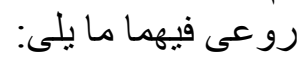
- يحملان نفس المؤ هل العلمى فئ.

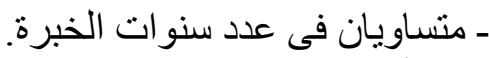

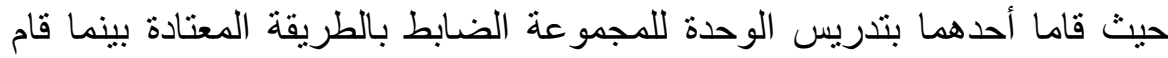

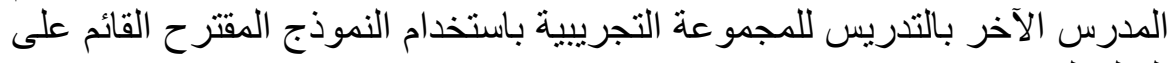
ז-ד التحقِق من تكافؤ المجموعتين التجريبية والضابطة فى المتغيرات التعلم السريع. التابعة قبلياً :

للتحقق من تكافؤ المجمو عتين فى كل من مهار ات التهن التفكير الجانبى و التنظيم الذاتى،

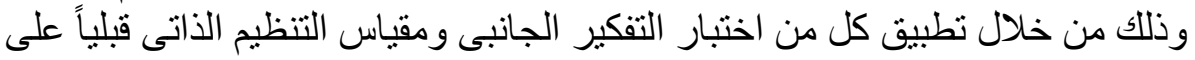

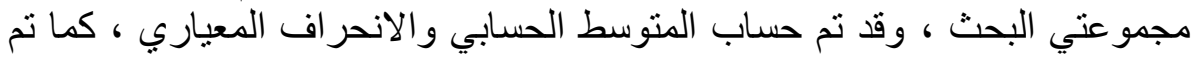
استخدام أختبار (ت) لحساب دلالة الفرق بين متوسطي درجات تلاميذ المجموعنين

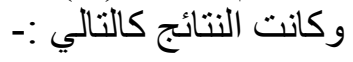




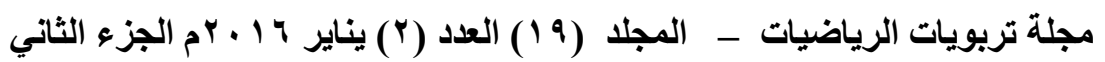

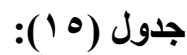

المتوسط الحسابى و الانحراف المعياري ، وقيمة (ت) (ت) ومستوى الدالالة الإحصائية

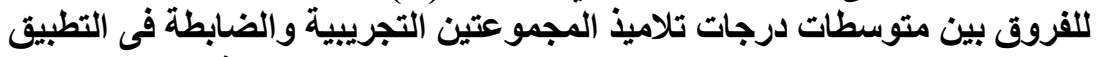

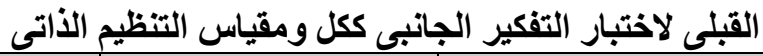

\begin{tabular}{|c|c|c|c|c|c|c|}
\hline \multirow{2}{*}{ الإحصائية } & \multirow[t]{2}{*}{ قيمة (ت) } & \multicolumn{2}{|c|}{ ال = ج ج ب تلميذ } & \multicolumn{2}{|c|}{ المجوع و ج تلتجيذ } & \multirow[t]{2}{*}{ نوع الاختبار } \\
\hline & & $r \varepsilon$ & $r^{\beta}$ & I & P & \\
\hline NS & •, $\{r T$ & r,qV & Tr,Tr & $1, v$ & Ir,AV & التفكير الجانبى \\
\hline NS & $\cdot, r+1$ & $\varepsilon, r$ & $\vee 9,90$ & 0,7 & $\Lambda \cdot, r r$ & التظظيم الأتى \\
\hline
\end{tabular}

NS

يتضح من الجدول السابق عدم وجود فرق ذو دلالة إحصائا

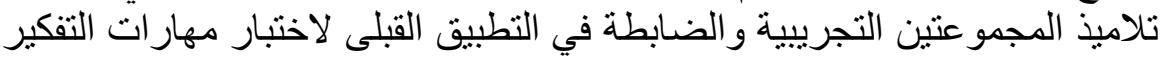

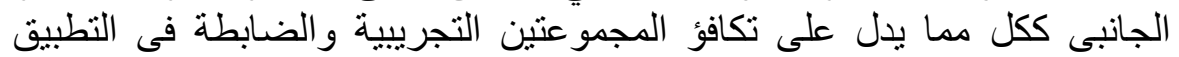

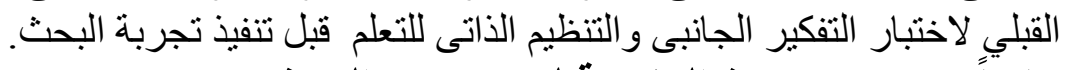

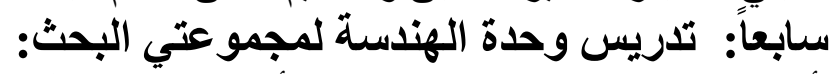

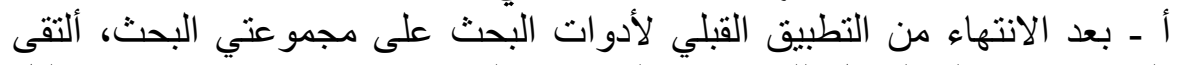

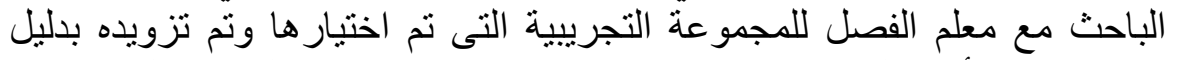

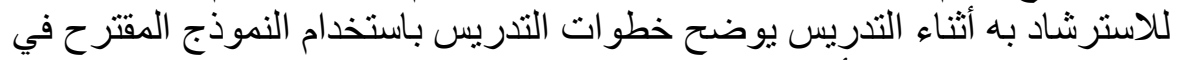

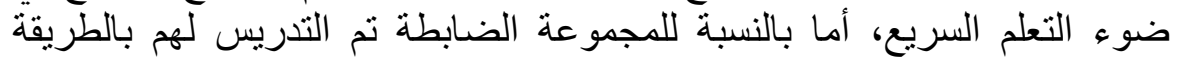

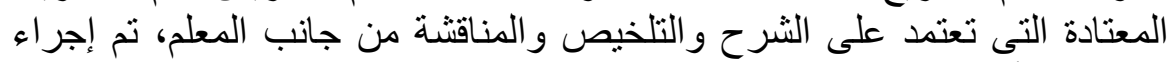

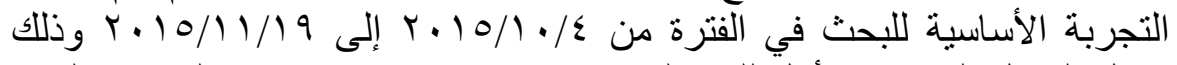

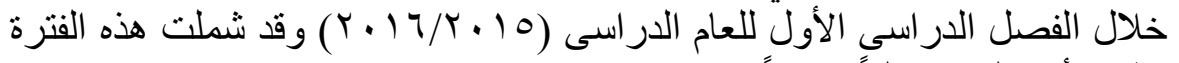
تطبيق أداة البحث قبلياً وبعدياً. بـ التطبيق البعدي لأدوات البـات البحث: بعد الانتهاء من تدريس ولبعد لادوات البحثة الهندسة لكل من المجمو عتين التجريبية و الضابطة تم

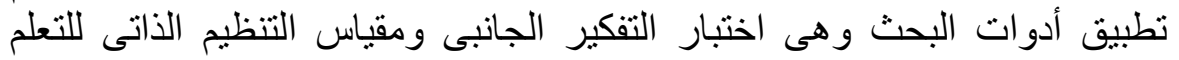

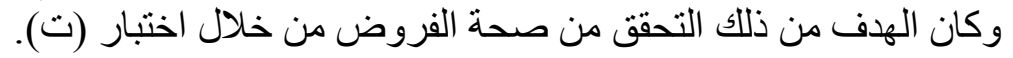

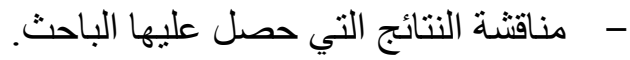

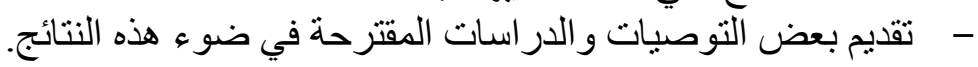


مجلة تريويات الرياضيات - المجلد (9 ( ) العدد (Y) يناير 17 ـ ب م الجزء الثاني

عرض التتائج ومناقشتتها وتفسير ها:

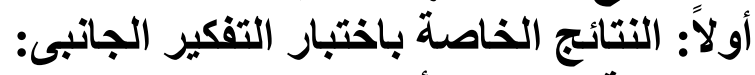

اختبار صحة الفرض الأول: الأنة الفاصن

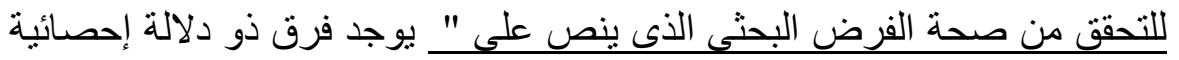

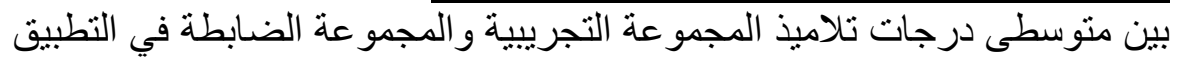

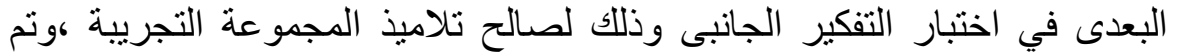

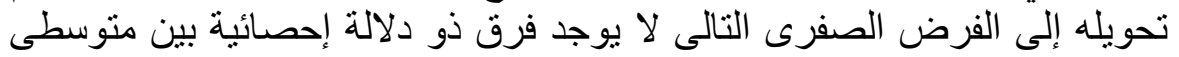

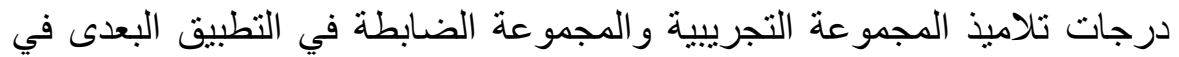

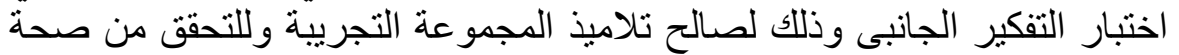

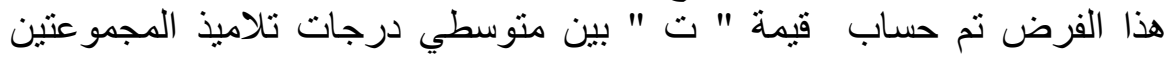

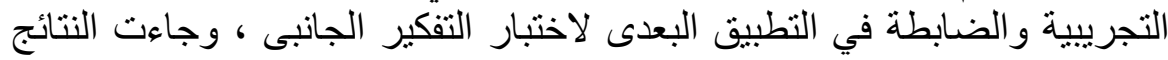

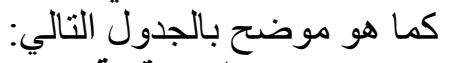

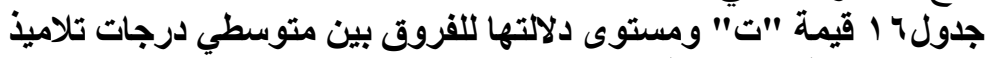

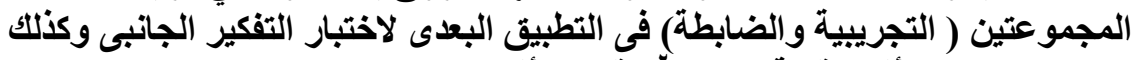

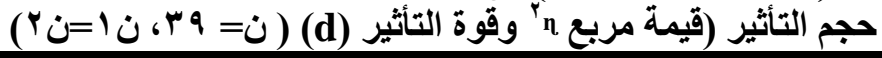

\begin{tabular}{|c|c|c|c|c|c|c|c|}
\hline $\begin{array}{c}\text { قوة التأثير } \\
\text { (d) }\end{array}$ & إيتا؟ & الدلالة & قيمة " ت" & $\varepsilon$ & r & المجموعة & الاختبار \\
\hline \multirow[b]{2}{*}{$r, r r$} & \multirow{3}{*}{$\cdot, \vee \vee \leftarrow \varepsilon$} & \multirow{3}{*}{ ا +, } & \multirow{3}{*}{$1 \leqslant, \leqslant 1$} & 1,9 & $\varepsilon, \mu \wedge$ & التجريبية & \multirow{3}{*}{ جوليدة ادراكات } \\
\hline & & & & \multirow[t]{2}{*}{$\cdot, \wedge \wedge$} & \multirow[t]{2}{*}{1,01} & \multirow[t]{2}{*}{ الضابطة } & \\
\hline مرتفع & & & & & & & \\
\hline$r, V Y$ & \multirow{3}{*}{$\cdot, 7 \leq 9$} & \multirow{3}{*}{ ال• دال عند } & \multirow{3}{*}{$11, \wedge \vee$} & & & & \multirow{3}{*}{ جليدليد مفاهيم } \\
\hline \multirow[t]{2}{*}{ مرتفع } & & & & $1, \cdot v$ & $\varepsilon, 91$ & التجريبية & \\
\hline & & & & $\cdot, \vee \vee 4$ & $r, \leqslant 0$ & الضابطة & \\
\hline \multirow[b]{2}{*}{1,71} & \multirow{3}{*}{ • } & \multirow{3}{*}{ ال• } & \multirow{3}{*}{$v, \cdot 11$} & $\because \wedge \wedge$ & $r, \wedge 1$ & التجريبية & \multirow{3}{*}{ توليد أفكار } \\
\hline & & & & \multirow[t]{2}{*}{$\cdot, \leqslant V$} & \multirow[t]{2}{*}{1,71} & \multirow[t]{2}{*}{ الضابطة } & \\
\hline مرتفع & & & & & & & \\
\hline$r, \leqslant r$ &., 097 & دال عند & $1 ., 090$ & $1, r r$ & r, & التجريبية & توليد بدائل \\
\hline
\end{tabular}


مجلة تربويات الرياضيات - المجلد (9 1 ) العدد (ץ) يناير 17 ـ ب م الجزء الثاني

\begin{tabular}{|c|c|c|c|c|c|c|c|}
\hline مرتفع & & $\cdot, \cdot 1$ & & $\cdot$, & $\cdot, \vee \vee$ & الضابطة & جليدة \\
\hline \multirow[b]{2}{*}{ ץ, } & \multirow[b]{2}{*}{$\cdot, \bullet \wedge}$. & \multirow{2}{*}{ دال } & \multirow[b]{2}{*}{$1 \cdot, r_{0}$} & 1,14 & $r, q v$ & التجريبية & \multirow[b]{2}{*}{ توليدة إبداعات } \\
\hline & & & & $\cdot, \wedge 9$ & 1,01 & الضابطة & \\
\hline & \multirow[b]{2}{*}{$\cdot, \wedge \mathrm{V}$} & \multirow[b]{2}{*}{ دال عنـــد } & \multirow[b]{2}{*}{$r r, 1}$. & $r, Y T$ & $r \wedge, \vee q$ & التجريبية & \multirow[b]{2}{*}{ الاختبار ككل } \\
\hline مرتفع & & & & $r, \wedge r$ & $10, r \mu$ & الضابطة & \\
\hline
\end{tabular}

** دال عند مستوى I+..

يتضح من الجدول السابق وجود فرق ذو دلالة إحصـائية عند مستوى (1 · , • ) بين

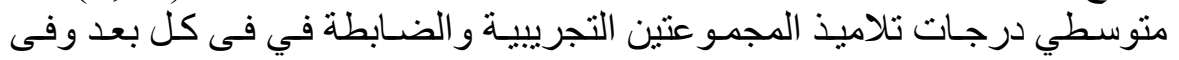

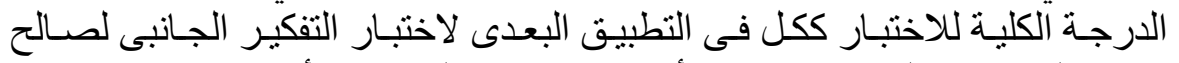

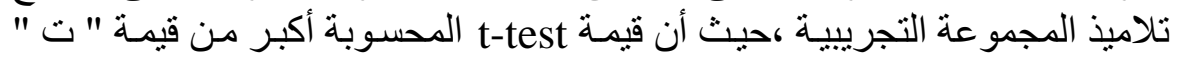

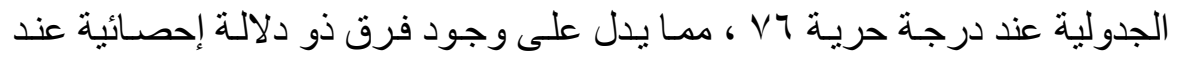

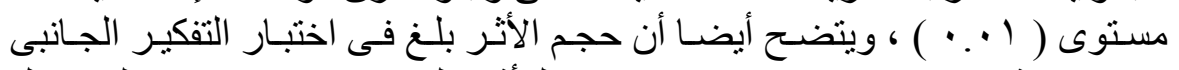

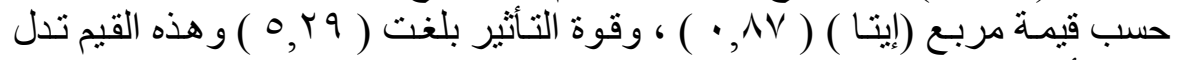

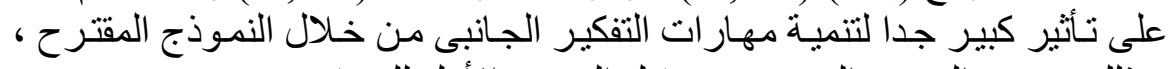
وبذللك برفض الفرض الصفرى ، ويقبل الفرض الأول للبحث.

\section{- - اختبار صحة الفرض الثانى:}

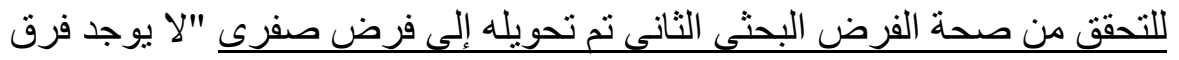

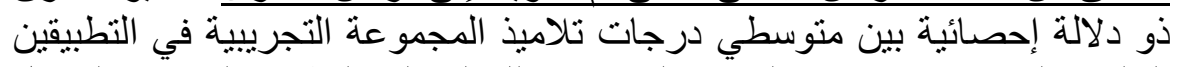

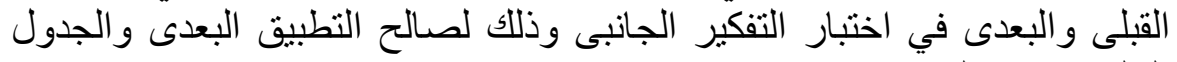

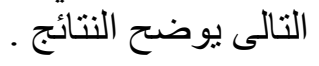


مجلة تربويات الرياضيات - المجلد (9 1 ) العدد (ץ) يناير 17 ـ ب م الجزء الثاني

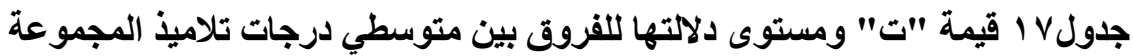

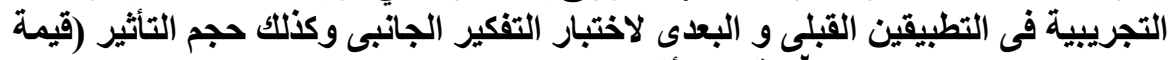

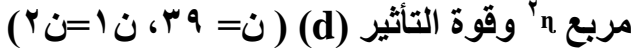

\begin{tabular}{|c|c|c|c|c|c|c|c|}
\hline $\begin{array}{l}\text { التأثير } \\
\text { (d) }\end{array}$ & إيتا؟ & مستوي & "تيمة " & $\varepsilon$ & s & عجة & مستويات الاختبار \\
\hline \multirow[b]{2}{*}{ r, Yr } & \multirow{3}{*}{ •, } & \multirow{3}{*}{ دال عند } & \multirow{3}{*}{ १, , . } & $1, \cdot \varepsilon$ & $\varepsilon, V \leqslant$ & بعدى ل بل & \multirow{3}{*}{ توليد ادراكات جديدة } \\
\hline & & & & •, Arr & $r, \leqslant \uparrow$ & قبلى ق ق & \\
\hline \multicolumn{4}{|l|}{ مرتفع } & & & & \\
\hline$r, \wedge r$ & \multirow{3}{*}{ צידי, } & \multirow{3}{*}{ 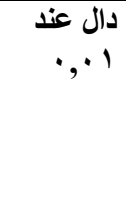 } & \multirow{3}{*}{ Ir, } & & & & \multirow{3}{*}{ توليد مفاهيم جديدة } \\
\hline \multirow{2}{*}{ مرتفع } & & & & 9,909 & 2,9 & بعدى ب بل & \\
\hline & & & & $1, \cdot 1$ & r,,$\wedge$ & قبلى ق ق ق & \\
\hline \multirow{2}{*}{$r, 19$} & \multirow{3}{*}{$\cdot, 0 \leqslant 0$} & \multirow{3}{*}{ دال } & \multirow{3}{*}{9,04} & 1,97 & $\varepsilon, \wedge \theta$ & بددى & \multirow{3}{*}{ توليد أفكار جديدة } \\
\hline & & & & $\cdot, \times 10$ & $r, V \varepsilon$ & قبلى ق ق & \\
\hline مرتفع & & & & & & & \\
\hline \multirow[b]{2}{*}{ r,,$\wedge$} & \multirow[b]{2}{*}{ or } & \multirow{2}{*}{ دال عند } & \multirow[b]{2}{*}{$q, q \leqslant$} & $1, \cdot 1$ & $0, r 1$ & 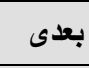 & \multirow[b]{2}{*}{ توليد بدائل جديدة } \\
\hline & & & & $\cdot, \wedge \wedge 0$ & $r, \wedge r$ & قبلى ق ع & \\
\hline \multirow[b]{2}{*}{$r, \leqslant 0$} & \multirow[b]{2}{*}{$\cdot, 7 \cdot 1$} & \multirow{2}{*}{ 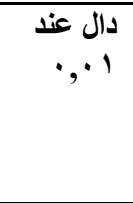 } & \multirow[b]{2}{*}{$1 \cdot, V Y$} & •, ११९ & $\varepsilon, \otimes q$ & بعدى & \multirow[b]{2}{*}{ توليا إبداعات جديدة } \\
\hline & & & & $\cdot, \wedge \wedge \varepsilon$ & $r, \leqslant 4$ & قبلى ق ق & \\
\hline \multirow[b]{2}{*}{$7,0 r$} & \multirow{3}{*}{$\cdot, 91 \leq$} & \multirow{3}{*}{ دال عنــــ } & \multirow{3}{*}{$r \cdot, 79$} & $r, \cdot r$ & $r 0, q r$ & بعدى ل بل & \multirow{3}{*}{ الاختبار ككل } \\
\hline & & & & $1, v$ & $I r, \wedge v$ & قبلى ق ع & \\
\hline مرتفع & & & & & & & \\
\hline
\end{tabular}

** دال عند مستوى 1 +. 
يتضح من الجدول السابق وجود فرق ذو دلالة إحصـائية عند مستوى (1 ·, • ) بين

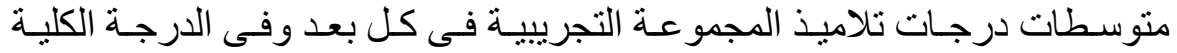

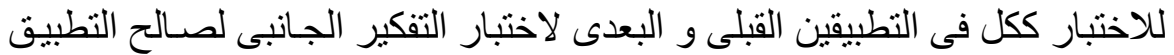

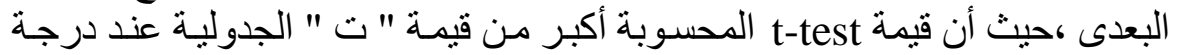

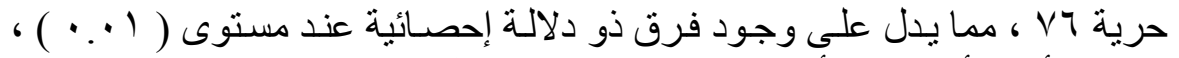

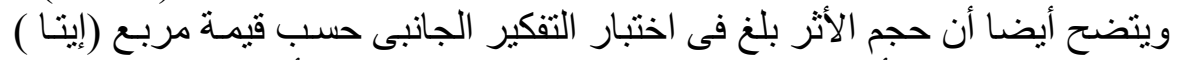

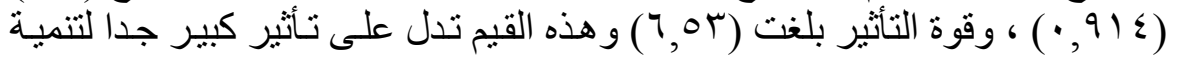

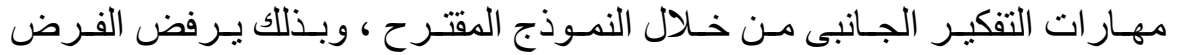
الصفرى ، ويقبل الفرض الثنانى للبحث.

حساب فاعلية النموذج المقترح القائم التعلم السريع فىى تنمية التفكير الجانبحي:

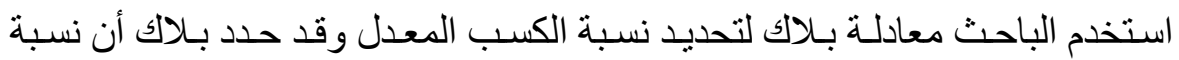
الكسب المعدل تقع فى المدى ( هذا المدى فإنها تكون فعالة وجاءت الدوى النتائج كما هو موضح بانت بالجدول التالي

جلول (1)

نتائج نسبة الكسب المعدل لبلاك لاختبار التفكير الجانبى للمجموعة التجريبية.

\begin{tabular}{|c|c|c|c|c|c|}
\hline دلالة النسبة & نسبة الكسب & للاخجتة الكلية & البعدى البط & المتوسطي & نوع الاختبار \\
\hline مقبولة لأنها أكبر & 1,19 & $r$. & $r o, q r$ & Ir,Av & التفكير الجانبى \\
\hline
\end{tabular}

يتضح من الجدول أن نسبة الكسب المعدل لاختبار التفكير الجانبى أكبر من الواحد

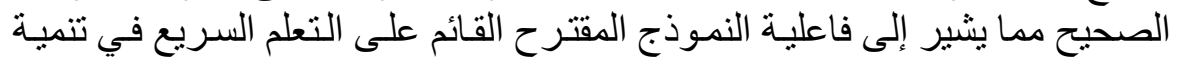
التفكير الجانبى لدى تلاميذ المجمو عة التجريبية المبنية

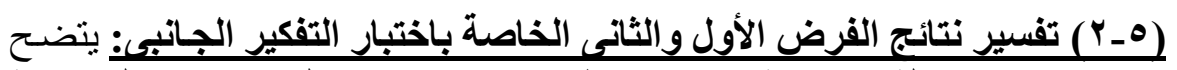

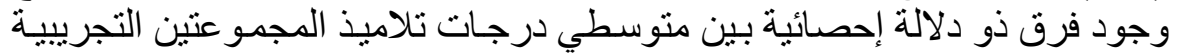

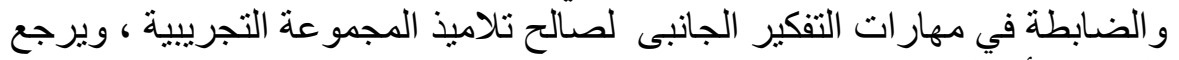

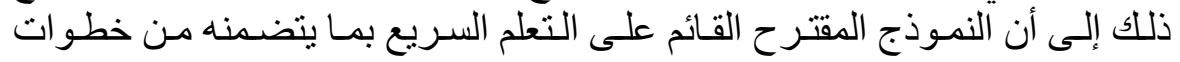

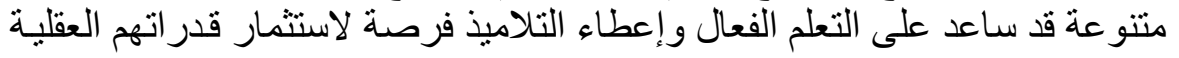

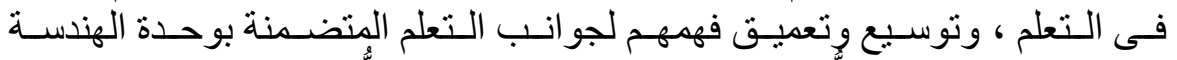

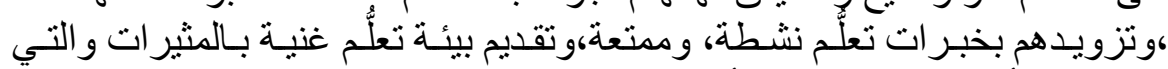
تناسب كل أنماط التعلم، وتوفر أنشطة تعليمية مشوقة تسهم في مساعدة التلاميذ على 


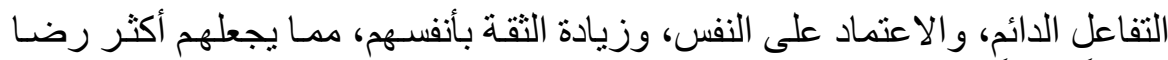

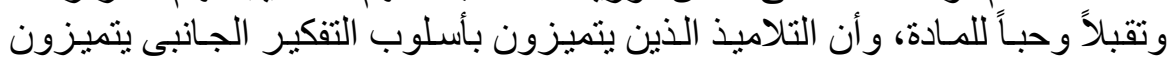

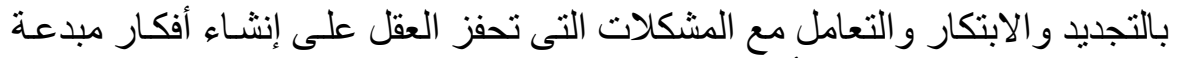
بو اسطة التركيز و الترنيب أثناء التفكير.

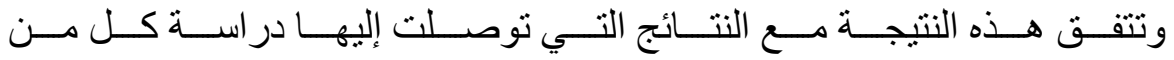
(Nicolette\&Birony,2010) و التـى أشـارت إلـى فاعليـة التعلم السـريع فـى تنميـة التحصيل الأكاديمى أكثر من التعلم بالطريقة المعتادة .

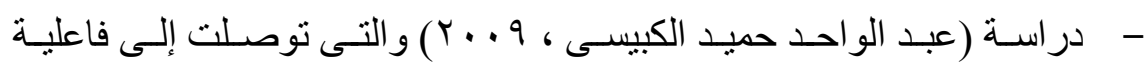

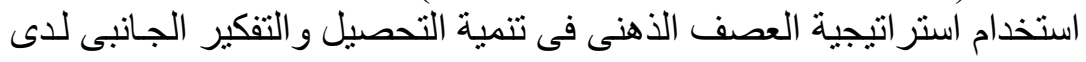

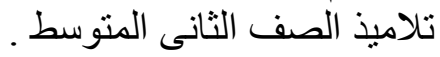

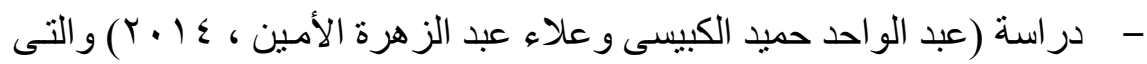

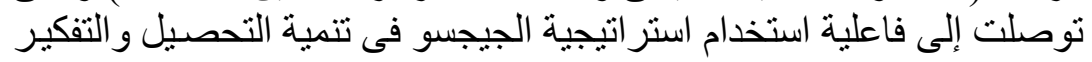
الجانبى لدى تلاميذ الصف الخامس التئن الابتدائي.

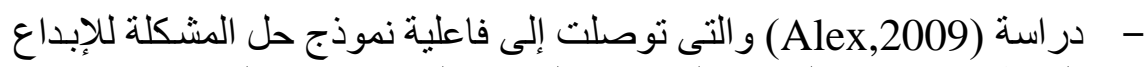

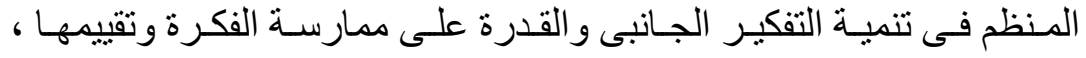
ووجود علاقة بين التفكير الجانبى ونتائج القرارات.

\section{ثانياً: التتائج الخاصة بمقياس التنظيم الأتى: - اختبار صحة الفرض الثالث:}

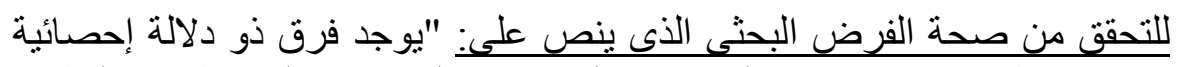

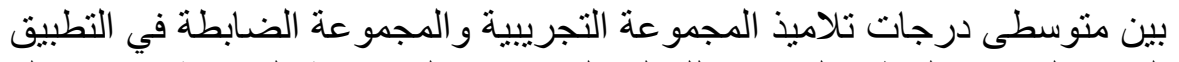

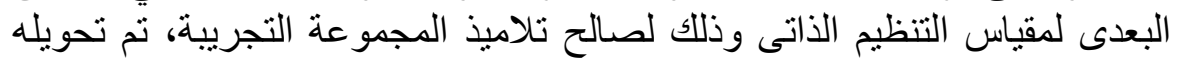

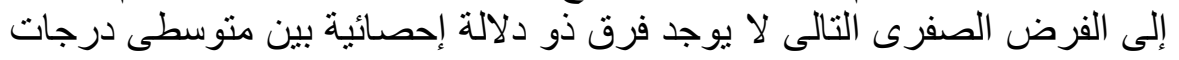

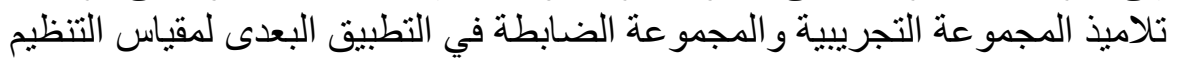

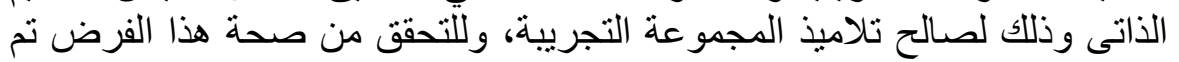

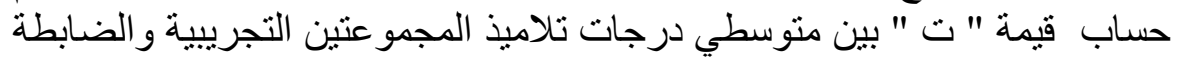

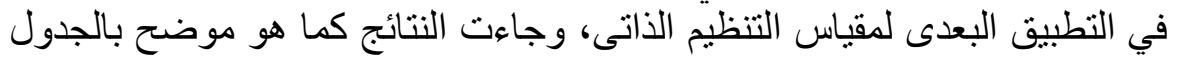
التالي: 
مجلة تريويات الرياضيات - المجلد (9 ( ) العدد (Y) يناير 17 ـ ب م الجزء الثاني

جدول 1 قيمة "ت" ومستوى دلالتها للفروق بين متوسطي درجات تلاميذ المجموعتين

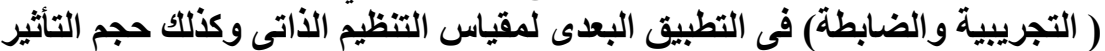

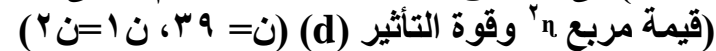

\begin{tabular}{|c|c|c|c|c|c|c|c|}
\hline $\begin{array}{c}\text { قوة التأثير } \\
\text { (d) }\end{array}$ & إيتا` & مستوى الدلالة & ق" ق" " & $\varepsilon$ & r & المجموعة & مستويات \\
\hline \multirow[b]{2}{*}{$r, .0$} & \multirow[b]{2}{*}{$\cdot, 799$} & \multirow[b]{2}{*}{ دال عند } & \multirow[b]{2}{*}{$|r, r|$} & $r, \wedge q$ & $r 0, v q$ & التجريبية & \multirow{2}{*}{ والأهدافع } \\
\hline & & & & r, & $17, \leqslant 9$ & الضابطة & \\
\hline \multirow{2}{*}{$r, q \wedge$} & \multirow{2}{*}{., 79.} & \multirow{2}{*}{ ا دال عند } & \multirow{2}{*}{$17 .+1$} & 0,00 & $r v, \wedge 0$ & التجريبية & \multirow{2}{*}{ الأتحكم } \\
\hline & & & & $r, 11$ & $1 \leqslant, 09$ & الضابطة & \\
\hline \multirow[b]{2}{*}{$\varepsilon, 11$} & \multirow[b]{2}{*}{$\cdot, \wedge \cdot \wedge$} & \multirow{2}{*}{ ا دال عند } & \multirow[b]{2}{*}{$1 V, q r$} & r,70 & $r \theta, r r$ & التجريبية & \multirow{2}{*}{ الأتسميع } \\
\hline & & & & $r, T r$ & $1 \leqslant, 7 \leqslant$ & الضابطة & \\
\hline \multirow{2}{*}{$\leqslant, \leqslant 0$} & \multirow{2}{*}{$\cdot, \wedge r r$} & \multirow{2}{*}{ الי } & \multirow{2}{*}{$19, \leqslant \leq$} & $r, q$ & $r q, \cdot 0$ & التجريبية & \multirow{2}{*}{ بالسجلات } \\
\hline & & & & $r, V v$ & 17,04 & الضابطة & \\
\hline \multirow{2}{*}{$\varepsilon, 9$} & \multirow{2}{*}{$\cdot, \wedge \cdot \vee$} & \multirow{2}{*}{ دال عند } & \multirow{2}{*}{$1 v, \wedge 0$} & $\varepsilon, 1$ & $r q, \wedge r$ & التجريبية & \multirow{2}{*}{ المعرفة } \\
\hline & & & & $r, 01$ & $1 r, 0$ & الضابطة & \\
\hline \multirow{2}{*}{$\Lambda, \cdot r$} & \multirow{2}{*}{$\cdot, 9 \leq 1$} & \multirow{2}{*}{ دال عنــــ } & \multirow{2}{*}{$r \varepsilon, q v$} & $r \cdot, q$ & $\mid r \wedge, r \wedge$ & التجريبية & \multirow{2}{*}{ ككل المقياس } \\
\hline & & & & 7,79 & Ar, $q$ & الضابطة & \\
\hline
\end{tabular}

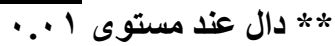

يتضح من الجدول السابق وجود فرق ذو دلالة إحصائية عند مستوى (1 +, • ) بين

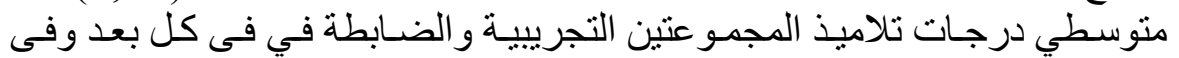

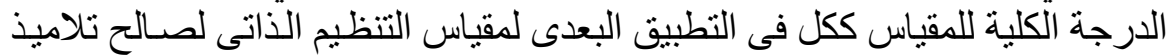

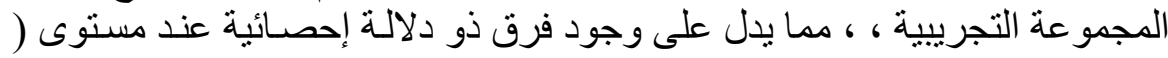

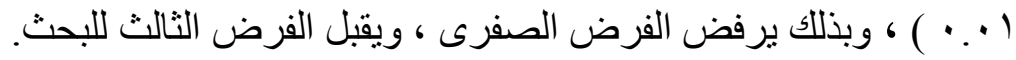

\section{اختبار صحة الفرض الرابع:}

للتحقق من صحة الفرض البحثى الذى ينص على: "يوجد فرق ذو دئ دلالة إحصائية

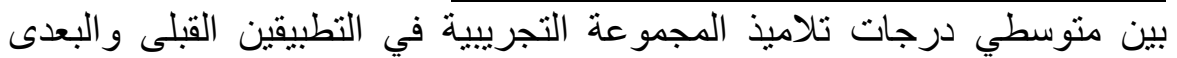

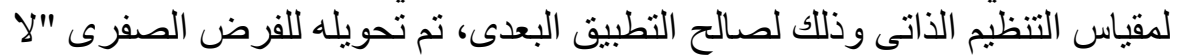




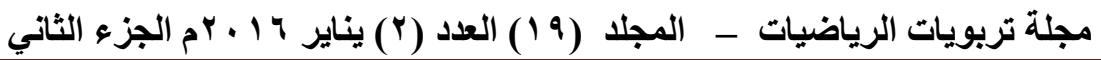

يوجد فرق ذو دلالة إحصائية بين متوسطي درجات تلاميذ المجموعة التجريبية في

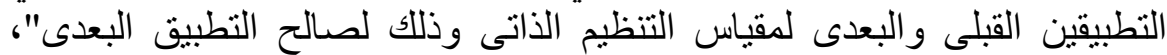
و الجدول التالي يوضنح ذللك:

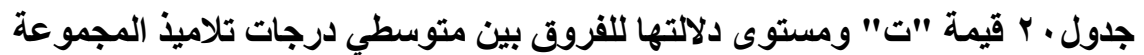

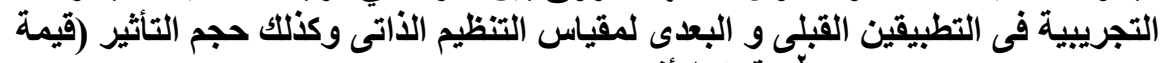

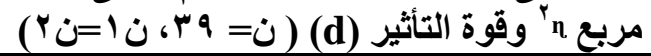

\begin{tabular}{|c|c|c|c|c|c|c|c|}
\hline $\begin{array}{c}\text { قوة التأثير } \\
\text { (d) }\end{array}$ & إيتا؟ & مستوى & قيمة " & $\varepsilon$ & b & التطبيق & الاختبار \\
\hline \multirow[b]{2}{*}{$0, r_{0}$} & \multirow[b]{2}{*}{$\cdot, \wedge \vee \vee$} & \multirow{2}{*}{ دال عند } & \multirow[b]{2}{*}{$r r, r q$} & $r, \wedge q$ & $r 0,1 q$ & البعدى & \multirow{2}{*}{ وضع الأهداف } \\
\hline & & & & $r, r \wedge$ & $1 Y, \leqslant 7$ & القبلى & \\
\hline \multirow{2}{*}{$r, \wedge r$} & \multirow[b]{2}{*}{$\cdot, \vee \wedge \bullet$} & \multirow{2}{*}{ دال عند } & \multirow{2}{*}{17,71} & 0,00 & $r v, \wedge 0$ & البعدى & \multirow[t]{2}{*}{ التحكم الأتى } \\
\hline & & & & $r, T r$ & Ir & القبلى & \\
\hline \multirow[b]{2}{*}{$\varepsilon, 7 r$} & \multirow[b]{2}{*}{$\cdot, \wedge \leq r$} & \multirow{2}{*}{ | ال, } & \multirow[b]{2}{*}{$r \cdot, 11$} & $r, 10$ & $r 0, r r$ & البعدى & \multirow[t]{2}{*}{ التسميع الذاتى } \\
\hline & & & & $r, r q$ & $|r, r|$ & القبلى & \\
\hline \multirow{2}{*}{$\varepsilon, \leqslant$} & \multirow{2}{*}{$\cdot, \wedge r}$. & \multirow{2}{*}{ اי دال عند } & \multirow{2}{*}{ 19,rr } & $r, q$ & $r q, \cdot 0$ & البعدى & \multirow{2}{*}{ والاحتجات } \\
\hline & & & & $r, \leqslant V$ & Ir,VV & القبلى & \\
\hline \multirow{2}{*}{ צ } & \multirow{2}{*}{$\cdot, \wedge r q$} & \multirow{2}{*}{ الי دال عند } & \multirow{2}{*}{$19, \cdot \varepsilon$} & $\varepsilon, 1$ & $r \bar{r}, \wedge r$ & البعدى & \multirow[t]{2}{*}{ ماوراء المعرفة } \\
\hline & & & & r,r & rr,r & القبلى & \\
\hline \multirow[t]{2}{*}{$\Lambda, r r$} & \multirow[t]{2}{*}{$\cdot, 9 \leq 0$} & \multirow[t]{2}{*}{ دال عند } & \multirow[t]{2}{*}{$r q, r r$} & $v, r$ & $\begin{array}{c}1 \mu \wedge, r \\
\wedge\end{array}$ & البعدى & \multirow[t]{2}{*}{ المقياس ككل } \\
\hline & & & & 7,7 & $\Lambda \cdot, r r$ & القبلى & \\
\hline
\end{tabular}

* : دال عند مستوى I ..

يتضح من الجدول السابق وجود فرق ذو دلالة إحصـائية عند مستوى (1 +, • ) بين

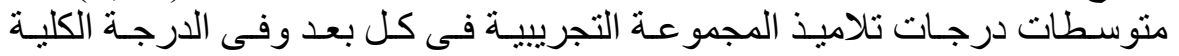

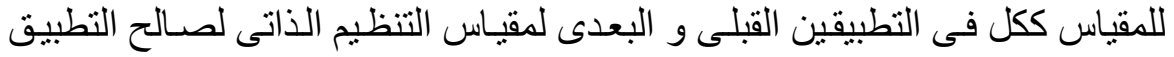

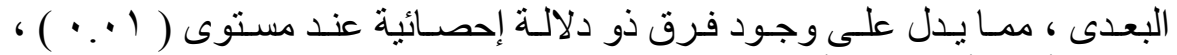

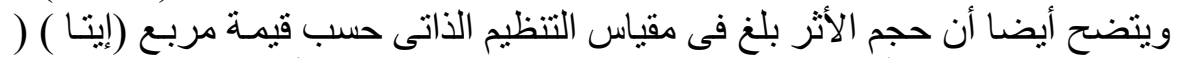

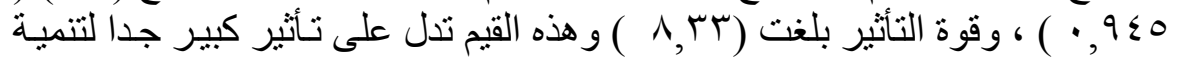

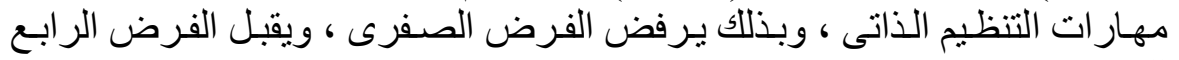


مجلة تربويات الرياضيات - المجلد (9 1 ) العدد (ץ) يناير 17 ـ ب م الجزء الثاني

حساب فاعلية النموذج المقترح القائم التعلم السريع فى تنمية التظظيم الذاتىى:

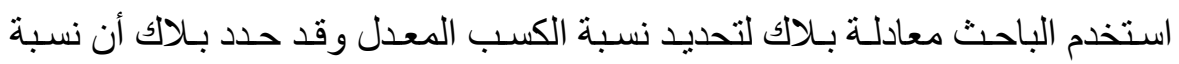
الكسب المعدل تقع فى المدى (

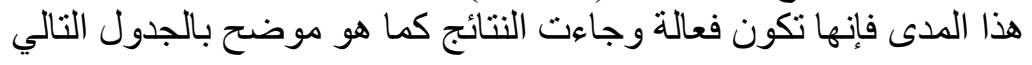

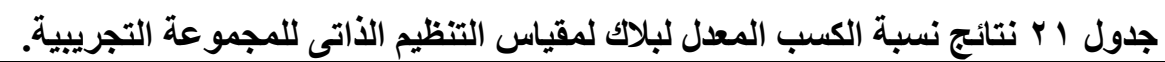

\begin{tabular}{|c|c|c|c|c|c|}
\hline دلالة النسبة & نسبة الكسب & اللارجتبة الكلية & البعدى البط & القبتليط & المقياس \\
\hline مقبولة لأنها أكبر من & $1, Y Y$ & 10. & $\mid r \wedge, r \wedge$ & $\Lambda \cdot, r r$ & الذاتظيم \\
\hline
\end{tabular}

يتضح من الجدول أن نسبة الكسب المعدل لمقياس التنظيم الذاتى أكبر من الواحد

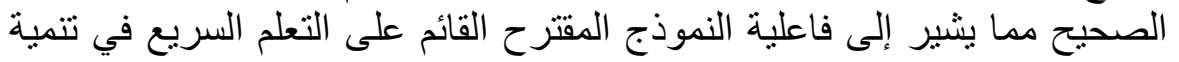
التنظيم الذاتى لدى تلاميذ المجمو عة التجريبية .

\section{تفسير نتائج الفرض الثالث والرابع الخاصة بمقياس التظيم الذاتحى:}

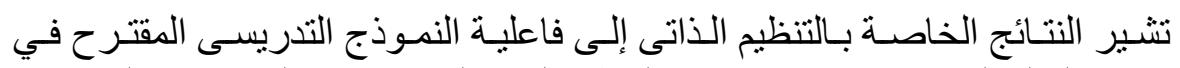

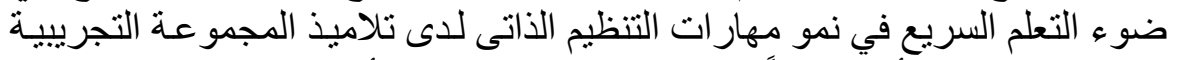

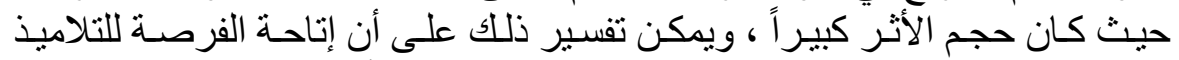

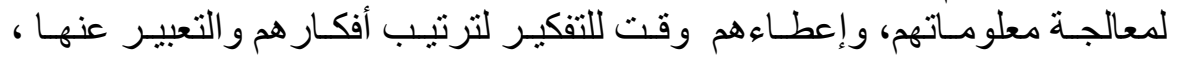

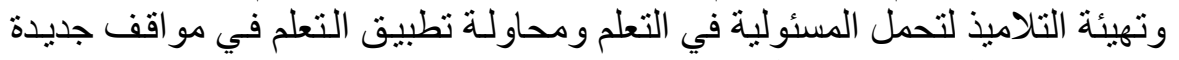

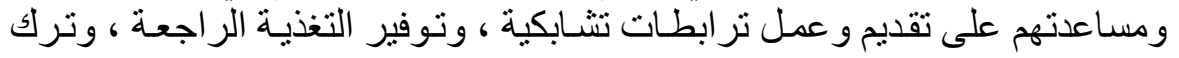

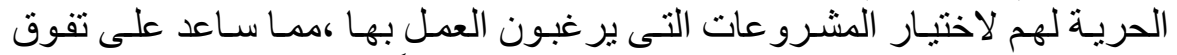

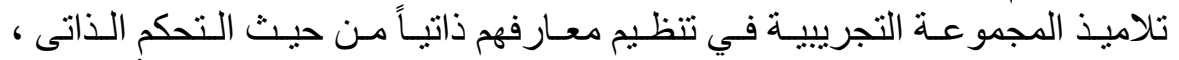

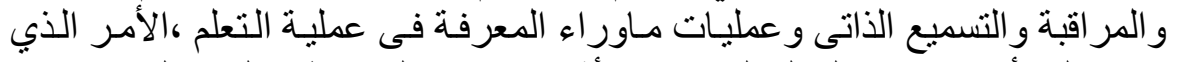

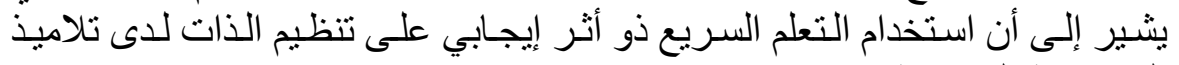
المجمو عة التجريبية أن التينية

وتتفق نتائج البحث مع در اسة (Arsal,2010) التى توصلت إلى أن استخدام كتابـة

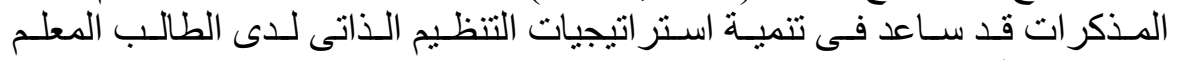

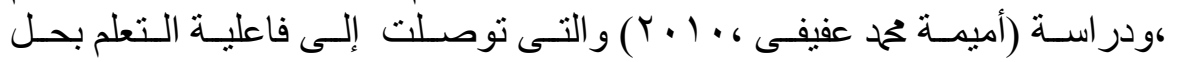
المشكلات فى تنمية التنظيم الذاتى لتعلم العلوم. 


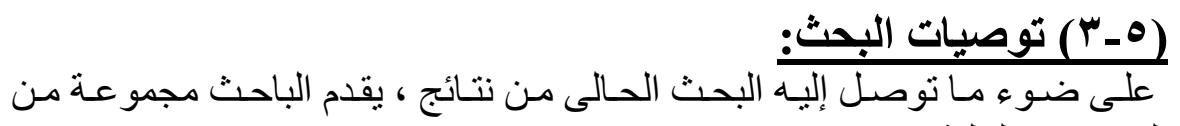
التوصيات التالية:

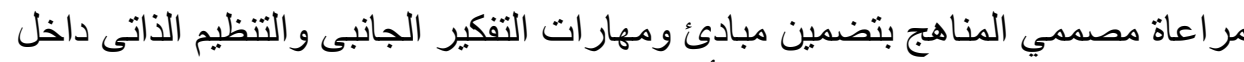

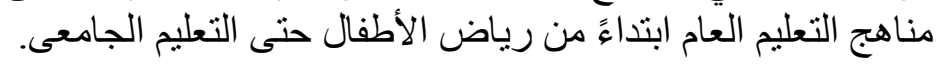

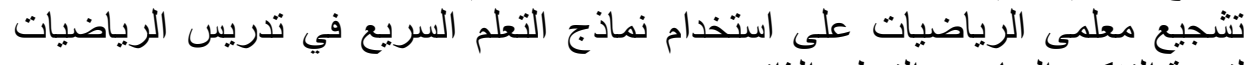

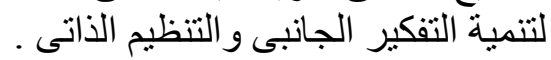

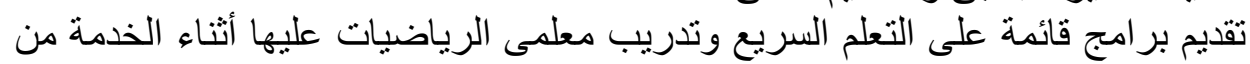

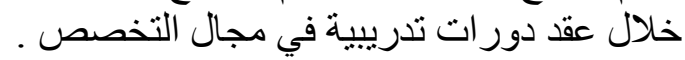

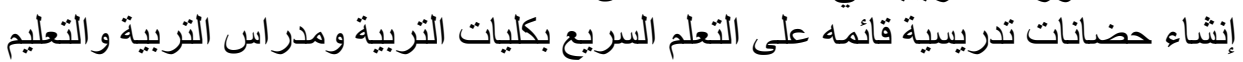

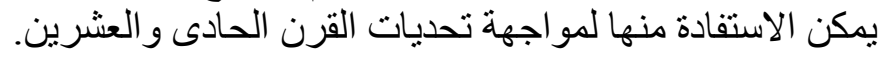
ضرورة تشجيع التلاميذ على الاستقلالية والاعتماد التهاد على النفس في جمع البيانات و التفكير بطريقة مبتكرة .

استكمالاً لموضوع مقترحات البحث الحالّى ، يقترح الباحث إجر اء البحوث و الدر اسات التالية

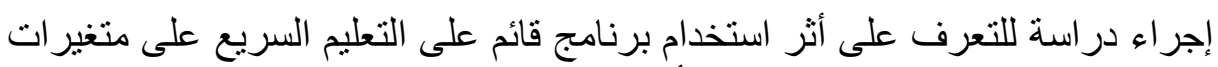

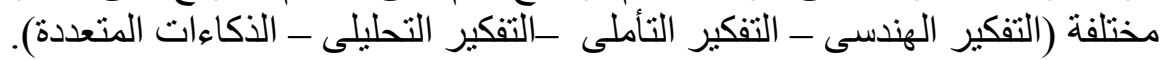
إجر اء در اسة متشابهة للدر اسة الحالية على مر احل مختلفة من التعليم : المرحلة الثانوية التهاية - المرحلة الجامعية.

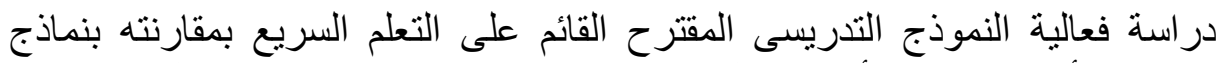

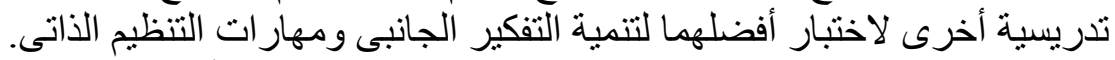

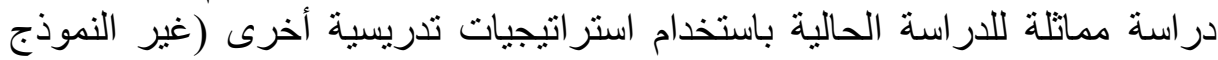

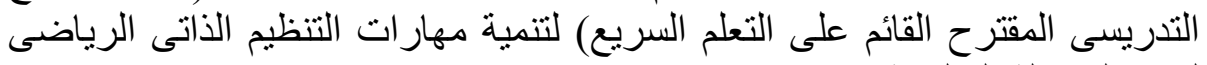
لنفس المرحلة التعليمية النقان. فاعلية استخدام نموذج التعلم السريع فى فئ تدريس الرياضيات لتنمية بعض مهارات

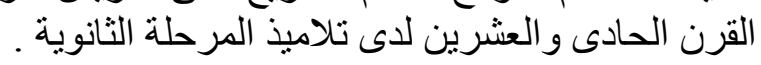

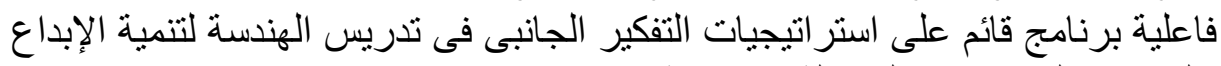

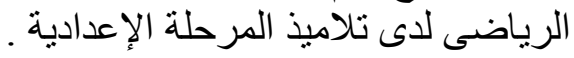




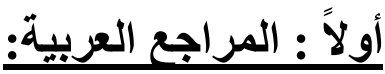

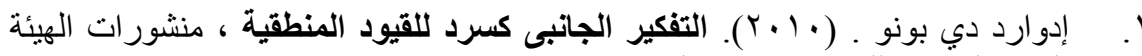

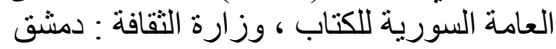

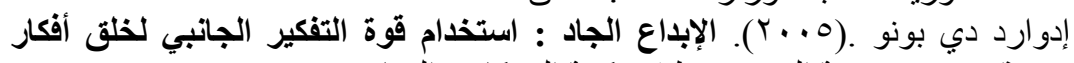

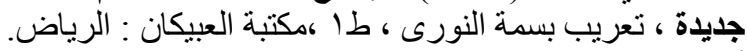

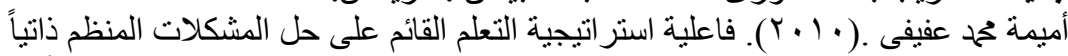

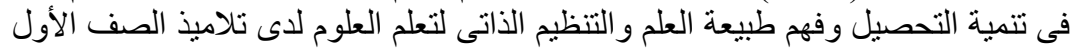

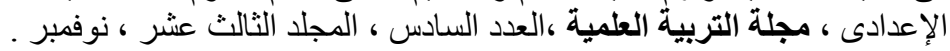

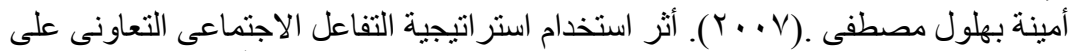

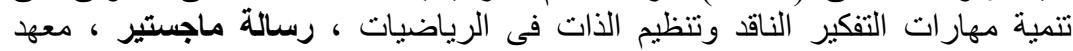

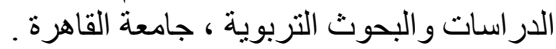

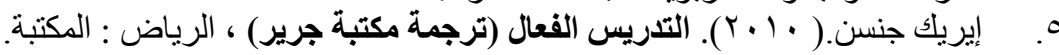

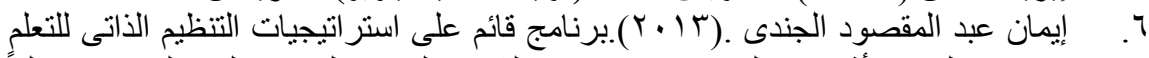

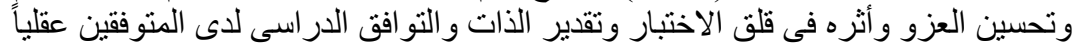

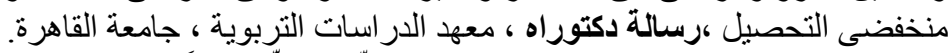

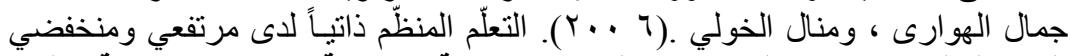

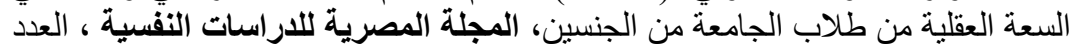

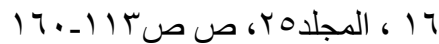

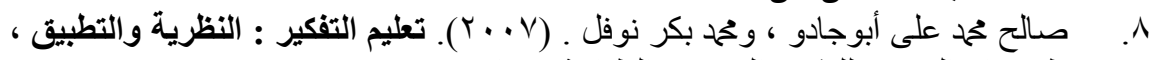

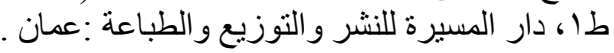

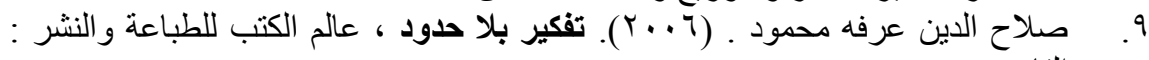

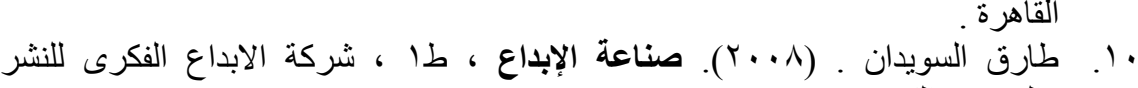

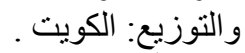

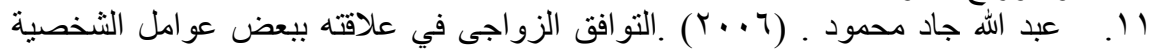

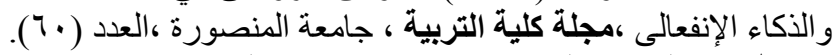

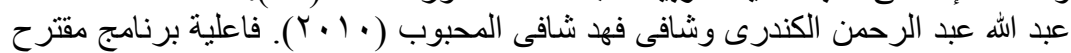

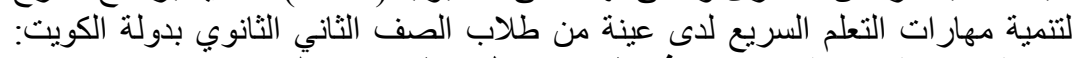

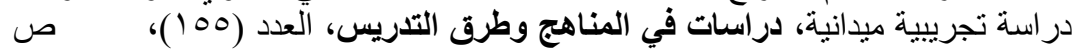

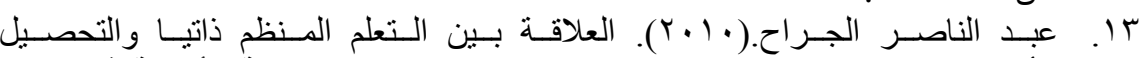

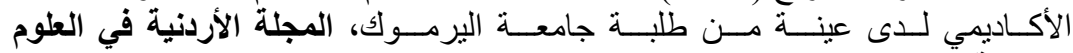

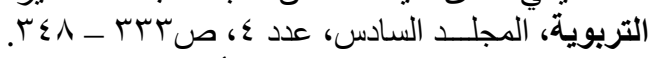

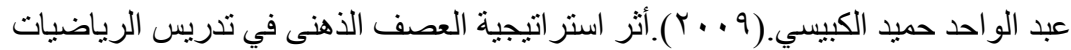

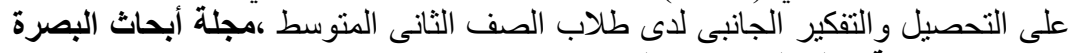

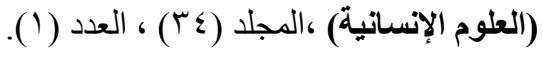




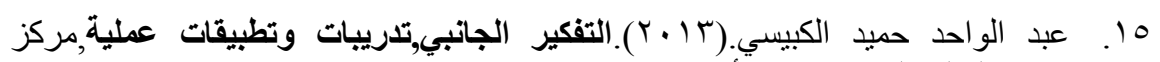
ا ديبونو لتعليم التفكير طا، الآردن :عمان.

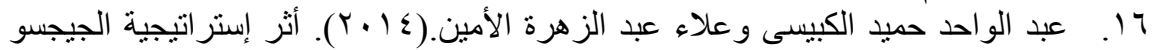

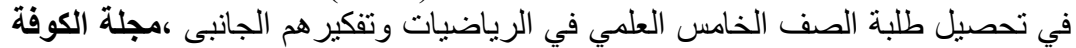

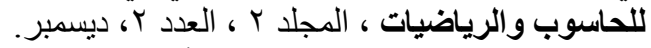

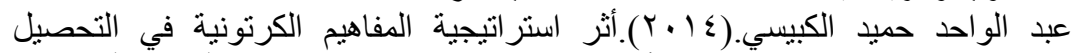

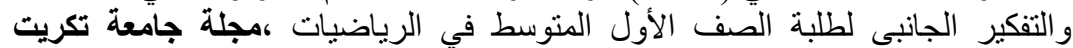

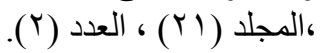

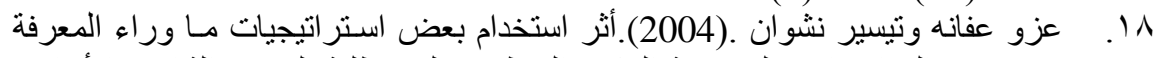

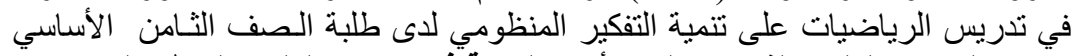

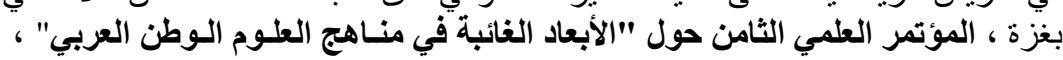

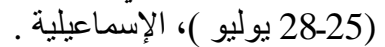

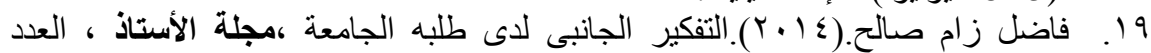
(ب.9)

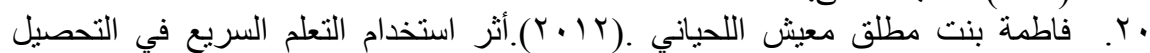

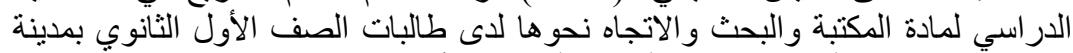

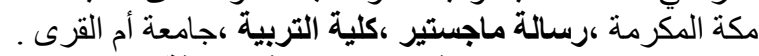

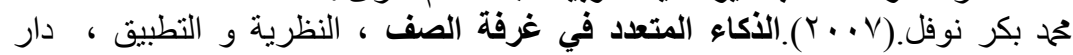

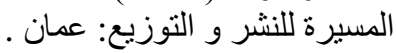

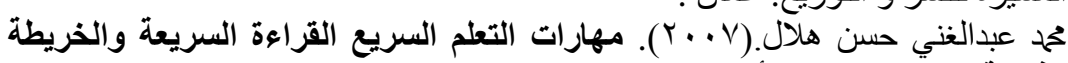

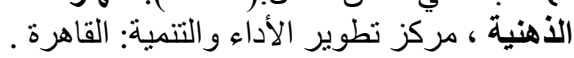

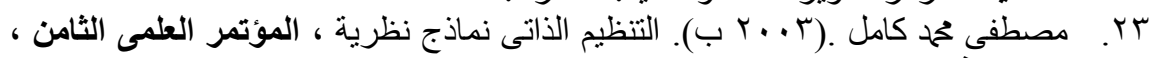

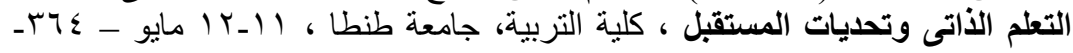
. 2 r.

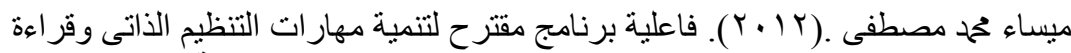

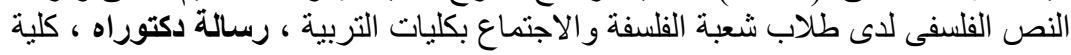
التربية ، جامعة بنها.

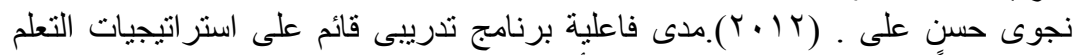

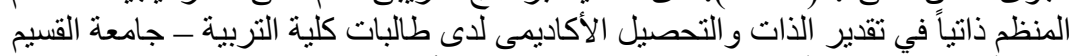

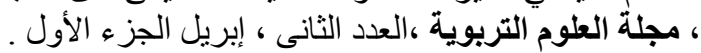

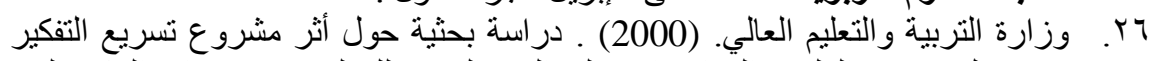

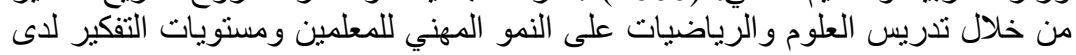
طلبة المشروع، رام الله - فلسطين والبين

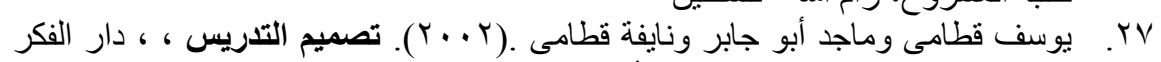
للطباعة و النشر و التوزيع ،عمان : الأردن البرن

ثاتياً: المراجع الأجنبية:

28. Alex,K. (7003):"Influence of Personal Preferred Creative Problem Solving Style \&Organizational Creativity Factors on Types of Lateral Thinking 
"Degree (Ph.D),The Senate of University Putra Malaysia ,Psasir, Upm. Edu.My/222371/A

29. Amelia,S.(2014). The Influence Of Accelerated Learning Cycle On Junior High School Students' Mathematics Connection Abilities, his paper has been presented at International Seminar on Innovation in Mathematics and Mathematics Education 1st ISIM-MED 2014 "Innovation and Technology for Mathematics and Mathematics Education" Department of Mathematics Education,Yogyakarta State

University Yogyakarta

30. Arsal , Z.(2010).The Effects of Diaries on self -regulation strategies of preserves science teachers .International Jornal of Environmental \&Science Education, Vol.5, No.1, Pp85-103.

31. Baker ,S.et al,.(2009).Teaching Writing to At-Risk students: the quality of evidence for self -regulated straegy development ,Exceptional Children, Vol.7,No.3,Pp.303-318.

32. Bembenutty,H.(2006).Self -regulation of learning

. Academic

Exchange Quarterly, Vol.(10), No.(4), Pp.221-248

33. Benhamu,A.(2007).Train the trainer in Accelerated Learning Techniques, Session Number

TU108.http://www.Pocs-international.com

34. Boyd, D. (2007). Effective Teaching in Accelerated Learning Programs. Adult Learning, Vol.

15,No.2, 40-43

35. Ganiron,T.(2013). Application of Accelerated Learning in Teaching Environmental Control System in Qassim University , International

Journal of Education and Learning, Vol.2, No.2, pp.27-38 http://dx.doi.org/10.14257/ijel.2013.2.2.03

36. Glossary of terms.(2014).The link: http://www.sdaccelerate.com/wpcontent/uploads/2013/04/glossary.htm

37. Gonzalez,S.et al .(2009).Self - Regulation of Academic Motivation :Advances in Structure and Measurement, www.aare.edu.au/05pop/gon05371.pdf

38. Harker,D\&Perry,C.(2007).Accelerating learning in marketing education using teams :principles and practice, $\underline{\text { Journal of Business Education \& }}$ Scholarship of Teaching

,Vol.1,Iss.1,http://www.ejbest.org

39. Jenkins, D.; Speroni, C.; Belfield, C.; Jaggars, S. \& Smith, S.(2010 ). Model for Accelerating Academic Success of Community College Remedial English Students: Is the Accelerated Learning Program (ALP) Effective and Affordable? CCRC Working Paper, No. 00

40. Kim,T.(2008).Accelerated learning :a study of the impact on adult learning ,attention ,and attitudes ,Micheal Worthington,Ph.D., A Dissertation 


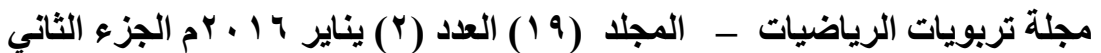

Presented in Partial Fulfillment of the Requirements for the degree

Doctor of Philosophy, Capella University

http://books.google.com.eg/books?id=bl0IIFgSklkC\&pg=PA4\&Ip $\mathrm{g}=\mathrm{PA} 4 \& \mathrm{dq}=$ studies+ineffective

41. Kumari,Sucheta \& Meenu Aggarwal,2012, Intelligence and Achievement as the Correlates of Lateral Thinking of the Student Teachers, International Indexed \& Referred Research Journal, June, 2012. ,VoL.IV ISSUE41

42. Lawrence,A and Xavier, A .(2013). lateral thinking of prospective Teachers, Light House, Journal of Educational Reflection, Vol.I: NO. 1

September-ISSN: 2319-5517

43. Meier,D .(2010). The Accelerated Learning Handbook: A Creative Guide to Designing and Delivering Faster, More Effective Training Programs. www.http: // sst5.com/Books/The-Accelerated-Learning-Handbook.pdf

44. Montalvo, F. T., \& Gonzalez Torres, M., C. (2004). Self-regulated learning: Current and future directions. Electronic Journal of Research in Educational Psychology, Vol.2,No.1, 1-34

45. Nicolette, L \& Briony, H (2010 ). Accelerated Learning: A Study of Faculty and Student Experiences, Innovative Higher Education, Vol.95 No.9, p290 -320

46. Pelco,E \& Reed,E .(2007).Self regulation and learning related social skills :intervention ideas for elementary school students .Preventing School Failure, Vol.51,No.3,Pro Quest ,No 1045988

47. Peter,J.(2006).Definition: Accelerated Learning, ttp://www.selfgrowth.com/articles/definition_accelerated_learning.ht $\underline{\mathrm{ml}}$

48. Pienaar,H.(2008).application of accelerated learning techniques with particular reference to multiple intelligences, Submitted in the fulfillment of the requirements for the degree of MASTER of EDUCATION in the subject DIDACTICS at the UNIVERSITY of SOUTH AFRICA SUPERVISOR

49. Pintrich ,P,R.(2000).The rol of goal orientation in Self -regulated of learning .In M.Puustinen ,\&(2001) models of Self-regulated learning :a review scandinavain ,Journal of Educational Research , Vol.45,No.3,Pp.269-286

50. Pintrich. P. R. (2004). A Conceptual framework for assessing motivation and Selfregulated learning in college students educational.

Psychology Review. Vol.16,No. 4. 385-407.

51. Richards,J.(2009). The Benefits of an Accelerated Learning Format in Teacher Education Programs , National University 11255 North Torrey Pines Road La Jolla, Ca 92037 School of Education

52. Serdyukov, P., Tatum, B.C., Greiner, C., Subbotin, I., \& Serdyukova, N. (2005, April). What is effective in teaching and learning:

Instructional methodologies, tools, and student learning experiences. Presentation 
at the $81^{\text {st }}$ Annual Meeting of the Western Association of Schools and Colleges, San Diego, CA.

53. Sloane, P. (2003). The leader's guide to lateral thinking skills : powerful problemsolving techniques to ignite your team's potential. London; Sterling, VA: Kogan Page

54. Smith, Alistair; to Avot, Marquez, Derek. (2010). Accelerated Learning User's Guide, (translation Allen Khoury), Damascus: Dar value, Dubai: ILLAFTrain to post.

55. Swenson, C. (2003). Accelerated and traditional formats: Using learning as a criterion for quality. New Directions for Adult and Continuing Education, , from: Ebsco database.

56. Tomas,G.(2013).Application of accelerated learning in teaching environmental control system in qassim university, International Journal of Education and Learning, Vol.2, No.2, http://dx.doi.org/10.14257/ijel.2013.2.2.03

57. Vrgut,A.(2008).Metacognitive ,achievement goals, study strategies and academic achievement :Pathways to achievement .Metacognition and Learning, Vol.3, No.2,123-146.

58. Wikipedia .(2010).Self -Regulated Learning the Free Encyclopedia http://en,wikipedia.org/wiki/self-regulated learning.

59. Wilkins, S; Martin, S \& Walker, I (2010). Exploring the Impacts of Accelerated Delivery on Student Learning, Achievement and Satisfaction,

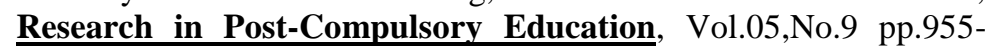
920.

60. Williams, R.(2008). The Impact of Accelerated Versus Traditional Learning with a Practical Test in Advanced Culinary Skills at Fox Valley Technical College, Research Paper

Submitted in Partial Fulfillment of the
Requirements for the Master of Science Degree With a Major in Career and Technical Education

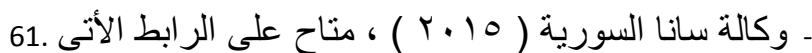

$$
\text { مواقع الانترنت : - 20 - مو }
$$
http://www.eftinfo.com/forums/showthread.php?t=1721\#sthash.MvgDG4qe.dpuf 62.

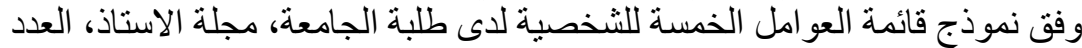

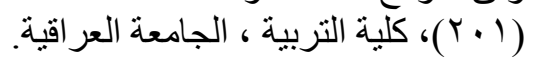

63. www.iasj.net/iasj?func=fulltext\&ald=30917 www.hrdiscussion.com 


\section{مجلة تربويات الرياضيات - المجلد (9 1) العدد (Y) يناير 17 ـ ب م الجزء الثاني}

64.

(مركز دبي للتعلم السريع).(Y (Y).ماهو التعلم السريع،

http://dalc.illaf.net/arabic/what_is_al.thtml

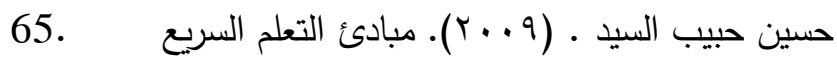

http://annajah.net/arabic/show_article.thtml?id=13 